Portland State University

PDXScholar

$12-30-2020$

\title{
A Historical Ecology of Aridland Springs in Desert National Wildlife Refuge, Nuwu/Nuwuvi (Southern Paiute/Chemehuevi) Ancestral Territory, Nevada
}

Yarrow Sarah Valentine Geggus

Portland State University

Follow this and additional works at: https://pdxscholar.library.pdx.edu/open_access_etds

Part of the Anthropology Commons, and the Desert Ecology Commons Let us know how access to this document benefits you.

\section{Recommended Citation}

Geggus, Yarrow Sarah Valentine, "A Historical Ecology of Aridland Springs in Desert National Wildlife Refuge, Nuwu/Nuwuvi (Southern Paiute/Chemehuevi) Ancestral Territory, Nevada" (2020). Dissertations and Theses. Paper 5636.

https://doi.org/10.15760/etd.7508

This Thesis is brought to you for free and open access. It has been accepted for inclusion in Dissertations and Theses by an authorized administrator of PDXScholar. Please contact us if we can make this document more accessible: pdxscholar@pdx.edu. 


\begin{abstract}
A Historical Ecology of
Aridland Springs in Desert National Wildlife Refuge,

Nuwu/Nuwuvi (Southern Paiute/Chemehuevi) Ancestral Territory, Nevada

by

Yarrow Sarah Valentine Geggus
\end{abstract}

A thesis submitted in partial fulfillment of the requirements for the degree of

\author{
Master of Science \\ in \\ Anthropology \\ Thesis Committee: \\ Jeremy Spoon, Chair \\ Virginia L. Butler \\ Alida Cantor \\ Portland State University \\ 2020
}


(C) 2020 Yarrow Sarah Valentine Geggus 


\section{ABSTRACT}

Aridland springs are among the most threatened ecosystems in the world (Stevens \& Meretsky 2008). Vital to desert ecologies and Indigenous cultures, these complex and individualistic ecosystems contain layered histories. To inform management in the changing landscape of Desert National Wildlife Refuge, a 1.6 million acre protected area in Southern Nevada, I conducted a historical ecology study of a sample of ten upland springs. Using a six-part interdisciplinary method incorporating interviews, archaeological survey, botanical survey, and archival research, I summarize findings into three broad eras: the Nuwu/Nuwuvi preContact Era, the Settler Era, and the U.S. Fish and Wildlife Service Era.

For millennia, Nuwu/Nuwuvi drank and camped near upland springs seasonally and still consider springs sacred and in need of specific care. EuroAmerican consumptive value of springs drove their modification along with large-scale changes to the landscape through prior appropriation for "beneficial use" water policy, entailing negative impacts upon springs. Springs remain developed under USFWS to maximize available water to Desert bighorn sheep. I found that the springs are likely moderately to highly disturbed in their current state due to changes to their physical integrity, vegetation, and riparian habitat. I identified climate change, groundwater extraction, and uncertain land tenure as major threats to these spring systems.

Recommendations for the future management of springs and surrounding archaeological resources include collaborative restoration to "naturalize" spring 
form and function alongside Nuwu/Nuwuvi tribal members. At the nexus of Indigenous territory, military expansion, drought, and an expanding desert metropolis, this case study connects political and cultural dimensions of humanspring relationships across the desert Southwest region, where springs hold disproportionately large importance both ecologically and culturally. 


\section{DEDICATION}

Dedicated to all Indigenous-led resistance and healing of the lands and waters. Dedicat als meus avantpassants,

Et pour Mamie. 


\section{ACKNOWLEDGEMENTS}

This project was made possible by the generous support and collaboration of many individuals. First, I express deepest gratitude to my advisor Dr. Jeremy Spoon, for his immense support and compassionate mentorship throughout this journey. Across the project's stages and extended length, he inspired me with infectious energy and drive, and accommodated meanders with the patience of a saint. In addition to rich, applied learning in the classroom, I have grown immeasurably from formative, practical experiences assisting with consultation and events among Nuwu/Nuwuvi tribes and Federal agencies in the Southern Great Basin. I am eternally grateful for these opportunities and influences, which motivated my research.

Sincere thanks to Anan Raymond with the U.S. Fish and Wildlife Service for encouraging this inquiry into springs and providing key funding and valuable guidance. Special thanks to Amy Sprunger for coordinating and accommodating my fieldwork at Desert NWR and providing comments, and sharing your passion for this vastly complex and special place. I am grateful to Bruce Zeller for sharing from his well of knowledge and animated stories. Huge thank you to Spencer Lodge and Sarah Bullock for their participation, insights, extensive guidance, and for bringing me into the field-- and back, in one piece! My research is especially indebted to Spencer Lodge, who led the archaeological surveys and whose comradery and feedback were fundamental to this project's success. Sincere 
thanks to Matt Flores and Dr. David Charlet for contributing their expertise and insights on spring ecology.

I am very grateful for my wonderful committee members, Dr. Virginia Butler, and Dr. Alida Cantor, who generously offered their time and comments. Your helpful critiques, warmth, and encouragement helped me enjoy the finish line. This project stands upon the shoulders of the diligent research of Kendra Wendel, and Brye Leftler, among others; I am thankful for their work and comradery.

Thank you to my friends from the Nuwuvi Working Group including Ron Escobar, Kenny Anderson, Betty Cornelius, Charlie Bulletts, and Richard Arnold, for your contributions to public lands conservation, and sharing your perspectives and laughter with me.

Thank you to the land and springs for having me as a visitor; your whispers I will always remember. Je remercie ma famille et mes amis pour tout leur soutien, amour, et encouragement durant cette aventure de recherche extraordinaire et longues années d'études--- surtout Marie Bassal, David Geggus, Alain Bassal, Marie Blanche Lopez, Mireille Chicheil, Marie Chicheil. Also Zeyah Rogé, Casey Miller, Cody Selker, Jess and Chandler Zadra, Maia Foster O’Neal. Je reconnais mes ancêtres bienveillants, mon Roussillon natal adoré, et mon privilège de connaitre mes racines-- ceux qui sans doute inspire mes convictions envers la préservation du patrimoine culturel. A maman, qui aurait aimé que je lui raconte l'histoire et la poésie des sources de ce paysage beau et insolite. 


\section{TABLE OF CONTENTS}

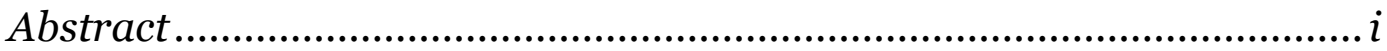

Dedication ................................................................................................

Acknowledgements............................................................................. iv

List of Tables ......................................................................................... vii

List of Figures...................................................................................... ix

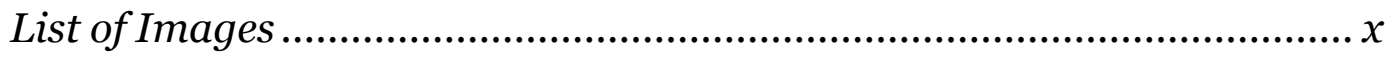

Chapter 1. Introduction .........................................................................

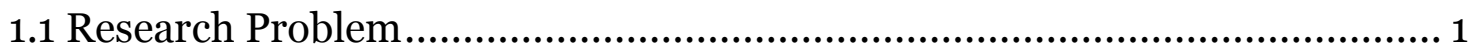

1.2 Research Framework: Historical Ecology …….......................................... 5

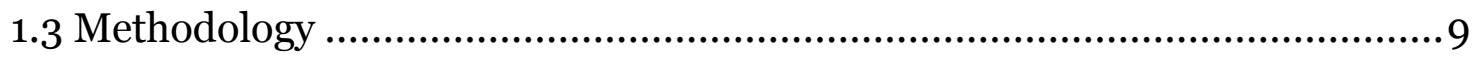

Chapter 2. Context ...............................................................................21

2.1 Aridland Springs Ecology .................................................................... 21

2.2 Setting: Desert National Wildlife Refuge ….............................................. 27

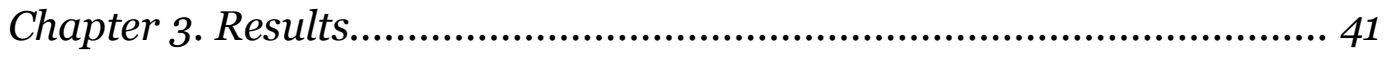

3.1 Nuwu/Nuwuvi pre-Contact Era, 11,500 BCE-1850 CE............................44

3.2 Euro-American Settler Era, 1850-1936 ................................................... 61

3.3 U.S. Fish and Wildlife Refuge Era: 1936-today ….................................... 77

3.4 Synthesis of Historical Ecology Eras ...........................................................95

3.4 Disturbance Index: Quantifying Sources of Spring Distubrance ...............102

Chapter 4. Discussion and Conclusion ................................................... 111

4.1 Discussion: Threats to Refuge Springs ……............................................. 111

4.2 Discussion: Restoration and Adaptive Management.................................121

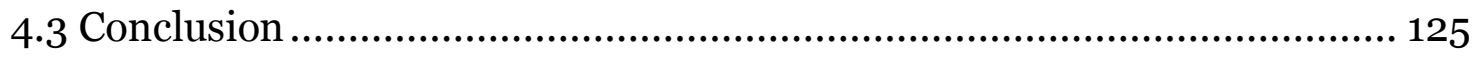


5.1 Recommendation for Archaeological Resource Management at Springs.. 129

Appendix A. Consent to Participate in Research. 166

Appendix B. Semi-Structured Interview Questionnaire History, Ecology, Management, and Restoration of Natural Springs at Desert National Wildlife

Refuge, Nevada. 168

Appendix C. Vascular Plant Species Identified During Survey (listed alphabetically) 171

Appendix D. Introduced Vascular Plant Species of DNWR Springs 174

Appendix E. Sample Spring Profile: Spring 9, Las Vegas Range 180 Appendix F. Situating Springs in the Pre-Human, Geological, and Global Context 188 Appendix G. Priority appropriation of water rights for the ten springs included in this survey presented in chronological order (USFWS archives, accessed 2016) 191 


\section{LIST OF TABLES}

Table 1. Methods and data inputs collected and summarized to inform the springs historical ecology

Table 2. Major historical eras defined for this study. (Source: Spoon and Arnold 2012; Fowler 2012; USFWS 2009) 12

Table 3. Springs included in study... 13

Table 4. The three spring spheres of discharge of upland Desert National Wildlife Refuge springs (adapted from Springer et al. 2008)..............................22

Table 5. Spring-upland gradient zones 27

Table 6. The 13 hydrographic basins of Desert National Wildlife Refuge (Source: NDWR 2014)

Table 7. Three over-appropriated sub-basins located within Desert National

Wildlife Refuge (Source: SNWA 2015b, NDWR 2014).

Table 8. Summary of springs archaeology. 53

Table 9. Presence/absence of types of pre-Contact artifact and features at each spring..... 54

Table 10. Presence/absence of historical artifact types at each spring.

Table 11. Settler activities near springs and associated archaeological sites ......70

Table 12. Sample of Refuge springs that need work to improve their health and function (USFWS 2013).

Table 13. Plant species richness survey results: sample of ten Refuge springs ..90

Table 14. Characteristics of the anthropogenic relationship to springs 101

Table 15. Common sources of disturbance observed in Great Basin/Mojave Desert springs (Sada and Vineyard 2002; Abele 2011; Unmark and Minckley 2008).

Table 16. Description of disturbance parameters and related ecological effects (Abele 2011; Fleishman et al. 2006). 109

Table 17. Disturbance matrix scores. These include tallies of six possible common sources of disturbance. 110

Table 18. Potential management scenarios characterized by domain..... 136 


\section{LIST OF FIGURES}

Figure 1. Close-up location map of the 10 springs in this study........................ 14

Figure 2. Location map of the ten springs in this study and administrative boundaries of Desert National Wildlife Refuge ..................................................29

Figure 3. Groundwater flow regions and basins of DNWR springs....

Figure 4. Geological Map of the Las Vegas Valley: Spring 8 and Spring 7 are located above the Las Vegas Valley Basin-Fill aquifer (adapted from Huntington 2010)

Figure 5. Detail of Geological Map of the Las Vegas Valley: Spring 8 and Spring 7 are located above the Las Vegas Valley Basin-Fill aquifer (adapted from Huntington 2010). 36

Figure 6. Complex directional flows of groundwater among basins and within the Desert National Wildlife Refuge boundary (USFWS 2009).

Figure 7. Over-appropriated basins within Desert National Wildlife Refuge ....40 Figure 8. Regional hydrographic flow systems involved in the proposed Springs Valley Pipeline Project (adapted from SNWA 2011a). .118

Figure 9. Detail of regional hydrographic flow systems involved in the proposed Springs Valley Pipeline Project (adapted from SNWA 2011a). 119 


\section{LIST OF IMAGES}

Image 1. Desert NWR Archaeologist taking measurements of a roasting pit,

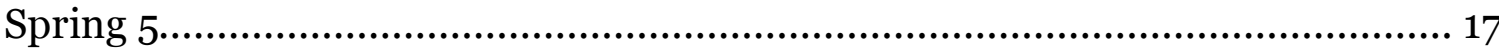

Image 2. Bighorn sheep herd near Spring 3, Sheep Mountains. Credit: Spencer Lodge.

Image 3. Large roasting pit at mouth of Spring 4 canyon, in an agave abundant area 50

Image 4. American Progress, John Gast, 1872. 61

Image 5. Cabin built in 1890 s near Spring 6,1975 (USFWS Archives). .68

Image 6. Older trough and bathtub contain Spring 5 . Historically used by livestock, hunters, and bootleggers, agave is abundant in this area and archaeologists noted the tubs may have been placed within the remains of a preContact roasting pit 72

Image 8. Wooden boards cover the source where water is piped around $30 \mathrm{ft}$ from source to bathtub drinkers (above) at Spring 3, Sheep Mountains

Image 9. Bathtub drinkers impound the diverted spring flow at Spring 3 , Sheep

Range.

Image 1o. Tanks at Spring 8 store both spring water and rain water which are dispensed through two drinkers.

Image 11. Spring 9 (Las Vegas Range) chronically fills with sediment ("natural disturbance") due to how it was developed at the base of cliff wall 104

Image 12. Window of Goshute (Western Shoshone) Reservation Headquarters reads, "SNWA: Sucks Native's Water Away. Stop Southern Nevada Water Association”. Photo by Max Wilbert, 2014. 118 


\section{LIST OF ACRONYMS}

USFWS United States Fish and Wildlife Service

DNWR Desert National Wildlife Refuge

DNWRC Desert National Wildlife Refuge Complex

NTTR Nellis Test and Training Range

DOD Department of Defense

GDE Groundwater dependent ecosystem

NRA National Recreation Area

NVCRIS Nevada Cultural Resources Information System

NVDCNR Nevada Department of Conservation and Natural Resources

SNPLMA Southern Nevada Public Lands Act

CFS Cubic Feet per Second

GPH Gallons per hour

SHPO State Historic Preservation Office

SNWA Southern Nevada Water Authority

NV Nevada

NWG Nuwuvi Working Group

PSU Portland State University

BCE Before common era

CE Common era

BP Before present 


\section{CHAPTER 1: INTRODUCTION}

\subsection{Research Problem}

Springs (also known as groundwater dependent ecosystems or GDEs) are vital to life in the desert. In Nuwu/Nuwuvi (Southern Paiute/Chemehuevi) territory of the Southern Great Basin/Mojave Desert region, these rare sources of water are life-sustaining entities and spirited places. From the Nuwu/Nuwuvi perspective, since the beginning of time when the world was new, springs require respect and proper spiritual care in order to keep the whole landscape in balance (Spoon et al. 2013; Spoon et al. 2015). In the late $18^{\text {th }}$ century, Spanish missionaries arrived in the then- verdant valley and named it Las Vegas for its spring-fed meadows. Euro-American settlers captured and developed all accessible springs to bring Mormonism, mining, railroads, ranching, and ongoing urban development to Nuwu/Nuwuvi homelands (Roberts and Ahlstrom 2012). Today, the once-profuse springs in Las Vegas Valley are dry and the meadows paved over. However, some springs persist in nearby protected lands, such as the mountainous, million-acre Desert National Wildlife Refuge (DNWR). Here, thirty-four upland springs, historically developed by ranchers, are now under management of the US Fish and Wildlife Service to help maintain critical habitat for Desert Bighorn sheep and other wildlife species (USFWS 2009).

Compared to lowland springs in the region, these minor, hard-to-access 
springs have unknown ecologies and anthropogenic histories. Although springs comprise only a minuscule fraction of the Earth's surface, these biodiverse ecosystems support more than 20 percent of the endangered species in the United States, as well as a high number of rare groundwater-dependent species (Sada \& Vineyard 2002). In the Great Basin and Mojave Deserts, the productivity, biological diversity, and cultural importance of GDEs are often orders of magnitude greater than surrounding dry areas (Stevens and Meretsky 2008; Sinclair 2018). Due to their outsized importance to human life for the last 11,00o years, these complex, individualistic ecosystems contain layered histories. In fact, aridland springs face severe anthropogenic and climatic impacts and are among the most threatened ecosystems in the world (Stevens \& Meretsky 2008). However, GDEs are inadequately protected and poorly understood, and long overlooked in conservation, education, and research. They evade straightforward classification, and this proves to be a major obstacle to their successful long-term management and conservation (Sada 2008); however, springs research offers the opportunity for dialogue among disciplines that rarely communicate with each other.

This research is among recent, emerging work to better understand human impact upon springs. Through the framework of historical ecology, this compilation of multidisciplinary data and analysis contributes to a holistic understanding of how spring systems changed over time, informs future management, and raises awareness of these important and scientifically obscure 
features of a cultural landscape. Historically, conservation in the United States was intimately tied with the removal and erasure of Indigenous peoples and their deep-rooted knowledge of the land and its stewardship (West et al. 2006). Integrating cultural history and meaningful tribal participation is an important and often overlooked aspect of natural resource conservation (Crumley 1994). As other studies show, place-based knowledge is complementary and convergent with Western science and can provide invaluable context and information where other data is absent (Berkes 1999; Shakeroff et al. 2011). In light of this, the combination of applied anthropology and historical ecology approaches can help elevate Indigenous knowledge and experience, alongside settler histories and physical sciences, to promote collaborative, mutually beneficial approaches to land management that are contemporary and adaptive.

This project chronicles the history of 10 springs, detailing their ecology, botany, archaeology, cultural use, and management over time and space. To compile these narratives, I conducted and analyzed six semi-structured interviews with local land managers and scientists, and synthesized water rights documentation, USFWS management notes, and other archival information spanning over a century. I assembled and analyzed all existing archaeological and vegetation research for springs-relevant data, which I expanded upon through conducting my own botanical species richness surveys and archaeological pedestrian surveys at each of the ten springs. Lastly, I wove these in-situ findings within the context of literature pertaining to the biophysical, ethnographic, and 
management pieces of the landscape's history.

I argue that three major "eras" encompass the most influential aspects of the changing human-spring relationship over time and space. The cultural, social, political, and economic shifts brought on by colonization entailed intensified extraction and disturbance to springs intended to support settlement and economic growth. The profound disruption of Nuwu/Nuwuvi traditional, reciprocal relationship to springs (Spoon et al. 2013) is implicated in (and even foretells) the observed changes to spring ecology and function. This research indicates that the 10 springs are moderately to severely disturbed as a result of developments made in the Settler Era which continue in the USFWS Era. I identified climate change, regional groundwater extraction, and uncertain land tenure as primary ongoing threats to spring degradation. I make a case for applying findings to spring restoration and linking Indigenous communities to federal land management, along with guided recommendations.

Results provide detailed, up-to-date information including the condition, disturbance rating, plant species composition, and archaeology, and establishes the historical ecological timeline and baseline of each specific spring. Findings voice not only the unique anthropogenic history and management needs of each spring, but also speak to springs history across the Refuge landscape, and to the drastic changes incurred broadly across aridland spring systems in Southwestern North America and beyond. Ultimately, this research demonstrates one 
application of historical ecology and political ecology to a land management problem with the ultimate aim of assembling perspectives from Indigenous peoples, settlers, governmental agencies, and ecological sciences into the broader conversation about ecosystem change and stewardship (Coughlan \& Petty 2012).

\subsection{Research Framework: Historical Ecology}

Historical ecology is a practical framework that considers humans an integral, active component of ecosystems that shape the environment (Crumley 2014). With the landscape as unit of study, historical ecology assembles multiple, disparate sources to evaluate both cultural and natural causes of variability over time and space. Through this lens, the landscape is a physical manifestation of history interpreted through various methods ranging from archival documents to carbon dating, oral history to herbarium specimens (Swetnam et al. 1999; Balee 2006). This framework considers human activity inherent to landscape forms and processes, and rejects the separation of nature and culture. As such, it rejects the erasure of Indigenous peoples implied in the romantic notion that preContact landscapes were "pristine" --- an idea central to justifications for both colonial conquest and early conservation alike in North America (Foster et al. 2004).

The program of historical ecology also recognizes that landscapes contain cultural meanings and are repositories of culture (Coughlan \& Petty 2012). It also includes oral histories as a practical reference tool to describe the geomorphic 
characteristics of shifting landscapes, such as the extent and distribution of historical wetlands, watersheds, rivers, and springs (Stein et al. 2010, Fowler 2002; Robertson and McGee 2003).

One of the advantages (and intricacies) of historical ecology framework is that it can harbor pluralistic understandings of phenomena across multiple ways of knowing: those stemming from different ontologies and epistemological systems, as much as across disciplinary traditions (Gagnon \& Berteaux 2009). Nuwu/Nuwuvi, like many Indigenous peoples cross-culturally, understand the natural world and its features as alive and spirited (Spoon et al. 2013; Bryan 2017). Based on this, I forward a springs-centered perspective that personifies these culturally layered systems as sentient, adaptive entities within a living landscape in flux. This characterization re-centers Indigenous knowing within non-equilibrium ecology (Berkes et al. 2000). Nonequilibrium ecology assumes that stochastic, variable abiotic parameters (e.g. rainfall) and external drivers (eg. human disturbance) generate systems with dynamic carrying capacities and multiple stable states. This is to say that they can change over time, in non-linear ways, and still functionally persist (Holling 1973). Considering the need to devise flexible management that works with the changing landscape, I frame the historical ecology of springs within Berkes et al.'s (2000) assertion that including appropriate local, Indigenous, and otherwise non-dominant ways of knowing within research is a necessary and adaptive process toward more effective and just policy (e.g. Armstrong et al. 2017). 
Conservation issues are often social issues, and thus integrating social science, history, and meaningful stakeholder participation are critical, often underutilized, aspects of natural resource management (Crumley 1994). The multi-pronged approach of historical ecology is one framework with the capacity to include and elevate local knowledge and the place-based, traditional ecological science of Indigenous cultures to promote collaborative, mutually-beneficial approaches to land management (Nadasdy 1999; Olsson et al. 2004; Gagnon Berteaux 2009). In some instances, place-based knowledge is complementary and convergent with scientific records and can provide invaluable context and information where other data are absent (Berkes et. al 2000; Shakeroff et al. 2011). However, such researcher-motivated approaches do not necessarily empower Indigenous peoples and are not a substitute for the practice of placebased knowledge of Indigenous peoples as they see fit on their homelands (Nadasdy 1999).

Historical ecology may bring together the perspectives of past and contemporary Indigenous peoples, governmental agencies, and other actors into the broader conversation about ecosystem change and stewardship (Coughlan \& Petty 2012). Numerous studies demonstrate the value of integrating historical perspectives into ecological studies, including oral history and local knowledge recorded with ethnographic methods. These can bring valuable insights to the structure and function of present-day ecosystems and help define conservation goals (Swetnam et al. 1999; Foster 2000; Gagnon \& Berteaux 2009; Berkes 2009; 
Egan and Howell 2001; Jackson and Hobbs 2009; Robertson and McGee 2003; Rosenberg et al. 2005).

The integrated framework of historical ecology makes it possible to understand and manage historical and contemporary ecosystems with the perspective of deep-time and supports the sustainable planning of their future (Swetnam et al. 1999). In multiple-use landscapes such as U.S. public lands, historical ecology can help managers embrace the complex, linked physical and social history of the ecosystems and landscapes in their charge and identify areas of participation for diverse stakeholders (Crumley 2014).

Reference conditions derived from historical research provide context for assessing contemporary processes and are useful for deciding upon justifiable goals and evaluate outcomes for ecological restoration programs (Egan \& Howell 2001). Restoration ecology is one application that modifies landscapes to restore a landscape's former functions, forms, and components. Based upon Western science, most environmental restoration is an extension of the views and values of governmental environmental management (Jackson \& Hobbs, 2009). Yet, Indigenous perspectives can add the invaluable, long-term view of traditional knowledge accumulated over thousands of years of inhabiting and interdependence with the landscape (Spoon et al. 2013). In some cases, ecological restoration may be used as a tool to reinstate ecosystem services such as habitat or spiritual value, as well as to mitigate anthropogenic degradation (Swetnam et al. 1999). 
In this paper, I employ the term "pre-Contact" instead of prehistorical to describe archaeological materials that precede Euro-American contact with Indigenous peoples. This is with the aim to frame the past in a way that acknowledges and honors Nuwu/Nuwuvi as a continuous, dynamic culture and people. I use Nuwu/Nuwuvi (meaning "the people") interchangeably to represent all seven bands. Nuwu is preferred by Las Vegas, Moapa, and Pahrump tribes, and Nuwuvi by the Chemehuevi tribe and Colorado River Indian Tribes and is also the term used to refer to the collective of bands/tribes as a Nation in the paper. Lastly, I employ the scientifically precise term, groundwater dependent ecosystem (GDE) to interchangeably refer to springs. Building upon the wideranging, synthetic foundation of historical ecology presented above, in the next section I discuss the multi-disciplinary methodology engaged to conduct this study.

\subsection{Methodology}

\section{Overview}

During fieldwork in October 2016, I employed a six-part, multi-disciplinary methodology to gather data about the 10 springs in my sample (data inputs are listed per domain in Table 1). These included: (1) six in-person interviews with land managers and local experts that I recorded and partially transcribed in order to code and analyze; (2) 10 spring monitoring surveys; (3) 10 archaeological surveys; (4) 10 botanical surveys; (5) review of Refuge documentary archives, 
including the annual narrative reports from 1938-1998 and the springs files, located at Desert NWR headquarters, Corn Creek. These included notes on spring water rights appropriations and developments, flow rates, climate, wildlife populations, non-native plants, and provided context of human use and activity around springs; and (6): review of academic and grey literature sources from the natural sciences, archaeology, and cultural anthropology related to Desert NWR. Prior ethnographies such as Isabel Kelly's manuscripts from 1933 detailed Nuwu/Nuwuvi practices at other area springs dating back to early contact with settlers or before; these helped provide a glimpse into possible analogous reference conditions from the pre-Refuge era (Kelly 1971; Kelly and Fowler 1986). 
Table 1. Methods and data inputs collected and summarized to inform the springs

historical ecology

\begin{tabular}{|c|c|c|c|c|c|}
\hline \multirow[t]{2}{*}{ ERA } & \multicolumn{3}{|c|}{$\begin{array}{l}\text { WHY: major drivers of human-spring } \\
\text { relations }\end{array}$} & \multirow{2}{*}{$\begin{array}{l}\text { HOW } \\
\text { Spring use \& } \\
\text { management } \\
\text { practices }\end{array}$} & \multirow{2}{*}{$\begin{array}{l}\text { WHAT } \\
\text { Spring ecology } \\
\text { \& } \\
\text { anthropogenic } \\
\text { impact }\end{array}$} \\
\hline & $\begin{array}{l}\text { Climate/ } \\
\text { non- } \\
\text { human } \\
\text { drivers }\end{array}$ & $\begin{array}{l}\text { Sociocultural } \\
\text { drivers: } \\
\text { worldview, } \\
\text { social } \\
\text { construction } \\
\text { of nature } \\
\end{array}$ & $\begin{array}{l}\text { Political \& } \\
\text { economic } \\
\text { drivers }\end{array}$ & & \\
\hline \begin{tabular}{|l|} 
Late \\
Pleistocene
\end{tabular} & Literature & $\mathrm{N} / \mathrm{A}$ & $\mathrm{N} / \mathrm{A}$ & $\begin{array}{l}\text { Archaeology, } \\
\text { secondary }\end{array}$ & Literature \\
\hline $\begin{array}{l}\text { Nuwuvi } \\
\text { Pre- } \\
\text { contact }\end{array}$ & Literature & $\begin{array}{l}\text { Ethnography } \\
\text { (secondary) } \\
\text { Archaeology, } \\
\text { primary and } \\
\text { secondary }\end{array}$ & $\begin{array}{l}\text { Ethnography } \\
\text { (secondary) } \\
\text { Archaeology, } \\
\text { primary and } \\
\text { secondary }\end{array}$ & $\begin{array}{l}\text { Ethnography } \\
\text { (secondary) } \\
\text { Archaeology, } \\
\text { primary and } \\
\text { secondary }\end{array}$ & $\begin{array}{l}\text { Literature } \\
\text { Ethnography } \\
\text { (secondary) } \\
\text { Archaeology, } \\
\text { primary and } \\
\text { secondary }\end{array}$ \\
\hline $\begin{array}{l}\text { Euro } \\
\text { American } \\
\text { Settler }\end{array}$ & $\begin{array}{l}\text { Literature } \\
\text { Interviews } \\
\text { Historical } \\
\text { Archive }\end{array}$ & $\begin{array}{l}\text { Literature } \\
\text { Interviews } \\
\text { Historical } \\
\text { Archive }\end{array}$ & $\begin{array}{l}\text { Literature } \\
\text { Interviews } \\
\text { Historical } \\
\text { Archive }\end{array}$ & $\begin{array}{l}\text { Literature } \\
\text { Interviews } \\
\text { Historical } \\
\text { Archive } \\
\text { Archaeology, } \\
\text { primary and } \\
\text { secondary }\end{array}$ & $\begin{array}{l}\text { Literature } \\
\text { Interviews } \\
\text { Historical } \\
\text { Archive } \\
\text { Archaeology, } \\
\text { primary and } \\
\text { secondary }\end{array}$ \\
\hline \begin{tabular}{|l|} 
USFWS \\
\end{tabular} & $\begin{array}{l}\text { Literature } \\
\text { Interviews } \\
\text { Historical } \\
\text { Archive } \\
\text { Archaeology, } \\
\text { secondary }\end{array}$ & $\begin{array}{l}\text { Literature } \\
\text { Interviews }\end{array}$ & $\begin{array}{l}\text { Literature } \\
\text { Interviews } \\
\text { Historical } \\
\text { Archive } \\
\text { Archaeology, } \\
\text { secondary }\end{array}$ & $\begin{array}{l}\text { Literature } \\
\text { Interviews } \\
\text { Historical } \\
\text { Archive } \\
\text { Archaeology, } \\
\text { primary and } \\
\text { secondary }\end{array}$ & $\begin{array}{l}\text { Literature } \\
\begin{array}{l}\text { Ethnography } \\
\text { (secondary) }\end{array} \\
\text { Interviews } \\
\text { Historical } \\
\text { Archive } \\
\text { Botanical } \\
\text { richness survey } \\
\begin{array}{l}\text { Disturbance } \\
\text { Index } \\
\text { Archaeology, } \\
\text { primary and } \\
\text { secondary }\end{array} \\
\end{array}$ \\
\hline
\end{tabular}


I organized a chronological synthesis of the human-springs histories across three major temporal eras. While these overlap and permeate one another, I define these broad time periods based on my argument that they represent significant shifts in the scale and/or intensity from the dominant human influence and activities on the local environment (Table 2, below). I completed spring profiles for each spring, and include Spring 9 as an example in Appendix E.

Table 2. Major historical eras defined for this study. (Source: Spoon and Arnold 2012; Fowler 2012; USFWS 2009)

\begin{tabular}{|c|l|l|l|l|}
\hline Era & $\begin{array}{l}\text { Late } \\
\text { Pleistocene } \\
\text { Pluvial }\end{array}$ & $\begin{array}{l}\text { Nuwuvi, } \\
\text { Pre- } \\
\text { Contact }\end{array}$ & $\begin{array}{l}\text { Euro- } \\
\text { American } \\
\text { Settler }\end{array}$ & $\begin{array}{l}\text { USFWS } \\
\text { Refuge }\end{array}$ \\
\hline \multirow{2}{*}{ Dates } & 40,000 B.C. & $\sim 11$, OOO B.C. & $\sim 1851$ A.D. & 1936 A.D. - \\
& $\sim 11$, ooo B.C & $\sim 1850$ A.D. & -1936 A.D. & present \\
\hline
\end{tabular}

Study Sample: 10 Springs in the Sheep Mountains and Las Vegas Mountains

I aimed to select a stratified sample of springs to represent a range of settings. With DNWR staff input, I considered mountain range, elevation, feasibility of access, vegetation community/ life zone; and landscape settings most likely to retain archaeological materials in their original context. The sample included 10 out of the 34 springs on the Refuge, not including those at Corn Creek, the site of Refuge headquarters located at the foothills of the Sheep And Las Vegas Mountains. Six of the springs in our sample are located in the 
Sheep Mountains and four are located in the Las Vegas Mountains. I narrowed these down based on their accessibility via two-track road and hiking. I excluded remote springs that required a technical approach or helicopter, and all springs located on the Nellis Test and Training Range portion of the Refuge. I conducted Geographic Information Systems (GIS) analysis to further narrow our sample to springs with areas of less than $20 \%$ slope within a 0.5 mile radius of the spring (Oyarzun 2016), due to the unlikely chance of finding surface archaeological materials in very steep settings (Interview with DNWR Archaeologist, 2016) Table 2 lists the 10 springs selected for my sample, mapped on Figure 1.

Table 3. Springs included in study

\begin{tabular}{|l|l|l|}
\hline Spring Name & Mountain Range & Elevation \\
\hline Spring 1 & Sheep Mountains & $5,750 \mathrm{ft}$ \\
\hline Spring 2 & Sheep Mountains & $5,767 \mathrm{ft}$ \\
\hline Spring 3 & Sheep Mountains & $6,200 \mathrm{ft}$ \\
\hline Spring 4 & Sheep Mountains & $5,55 \mathrm{oft}$ \\
\hline Spring 5 & Sheep Mountains & $5,94 \mathrm{ft}$ \\
\hline Spring 6 & Sheep Mountains & $7,972 \mathrm{ft}$ \\
\hline Spring 7 & Las Vegas Mountains & $4,470 \mathrm{ft}$ \\
\hline Spring 8 & Las Vegas Mountains & $5,02 \mathrm{ft}$ \\
\hline Spring 9 & Las Vegas Mountains & $6,482 \mathrm{ft}$ \\
\hline Spring 10 & Las Vegas Mountains & $5,440 \mathrm{ft}$ \\
\hline
\end{tabular}


Figure 1. Close-up location map of the 10 springs in this study

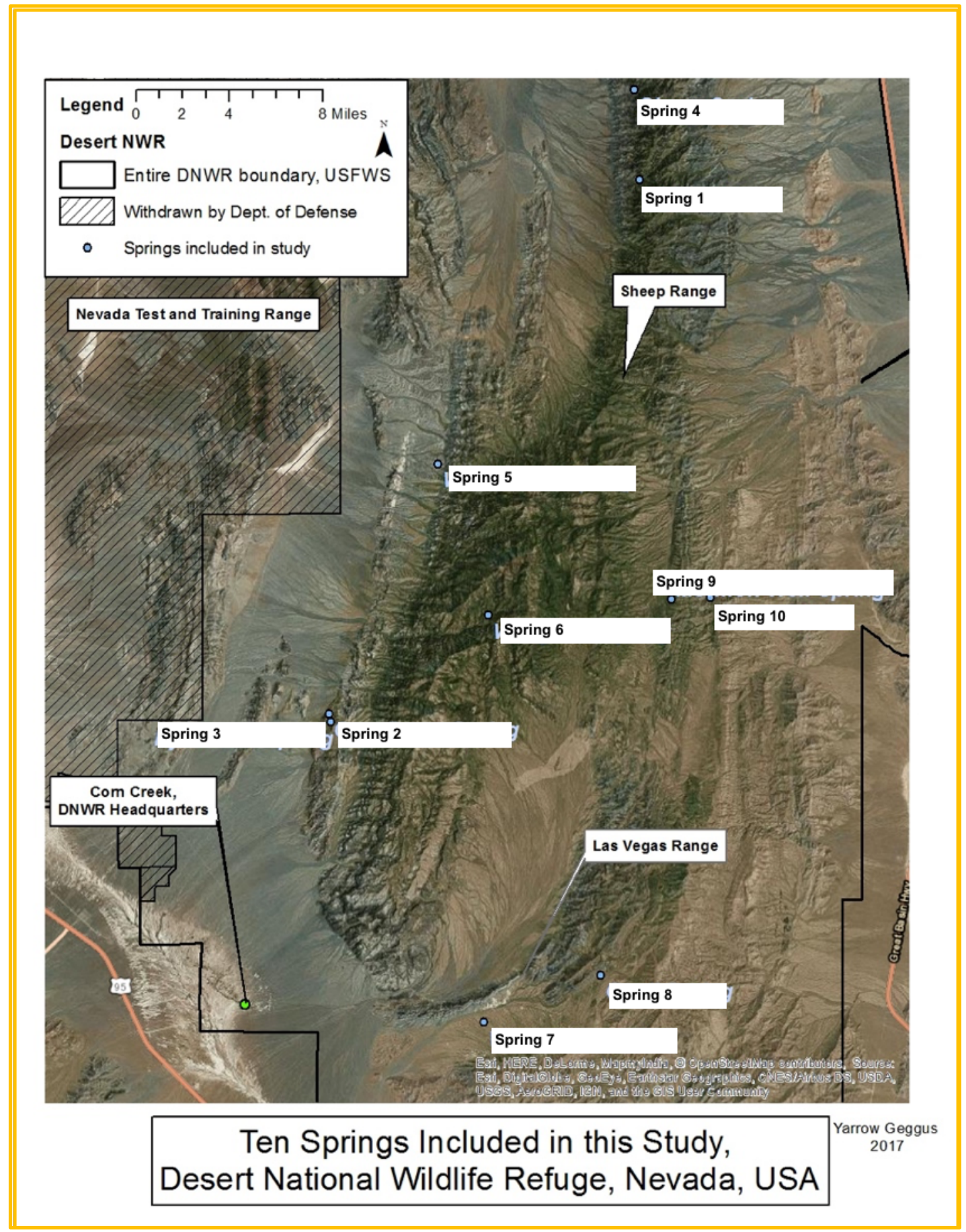




\section{Semi-Structured Interviews with Key Consultants}

I conducted six semi-structured interviews with consultants recruited using convenience and snowball sampling methods (LeCompte \& Schensul 2013). These entailed selecting participants that were easy to access, closely involved with the Refuge, and recruited via referral. Participants included former Refuge Manager/Biologist and the current Refuge Manager (who have a combined fifty years on the Refuge), the Refuge Archaeologist, the Refuge Biologist, as well as a local, applied botany expert, and a restoration ecology and wildlife management professional. I obtained Institutional Review Board approval and prior written informed consent from each participant (LeCompte \& Schensul 2013) (see Appendix A, Consent to Participate in Research.) A semi-structured interview format (Bernard 2011) allowed us to gather general data on the ecology of springs, perceptions of management and future needs, the human past and archaeology, and to explore certain topics in-depth based on the individual's expertise (Semi-Structured Interview Questionnaire in Appendix B). I partially transcribed and analyzed interview data using an inductive coding method and grounded theory (Bernard 2011; LeCompte \& Schensul 2013). This involved organizing the information I gathered according to categories that became apparent during the research process (e.g. specific spring, type of human activity and management) in order to condense interview transcripts and into a summary format. 
Archaeological Research and Field Survey

I conducted pedestrian field surveys at each of the 10 springs with the Desert NWR Archaeologist. Pedestrian surveys, also known as field-walking surveys, aim to record archaeological evidence and archaeological sites observable on the ground surface while walking a survey area (Banning 2002). I pre-determined survey areas based on a predictability model I created in GIS. Parameters for this model were based off of site-prediction models used in the Great Basin Desert, where terrain and proximity to water are significant factors in the distribution of artifacts and features (Oyarzun 2016). Parameters defined all areas within a 0.5 mile radius around each spring with a slope of less than $20 \%$, and highlighted landscape features such as ridges and saddles, where archaeological evidence was most likely to be found in context, based on information supplied by the DNWR archaeologist in preliminary interview. On average, this model selected $5 \%$ or less of the 505.6 acre/0.79 square mile area around each spring as suitable for pedestrian surveys. In addition to these, I compiled existing archaeological records from the Nevada Cultural Resource Information System (NVCRIS) database (NVHPO, 2016). I recorded all sites located within a 1.5 mile buffer around each of the ten springs. Additionally, I tabulated all archaeological evidence within a 1.5 mile buffer of each spring, by spring including type of artifact or feature, distance from spring, and eligibility to the National Register of Historic Places (Nevada SHPO, n.d.) 
Image 1. Desert NWR Archaeologist taking measurements of a roasting pit, Spring 5

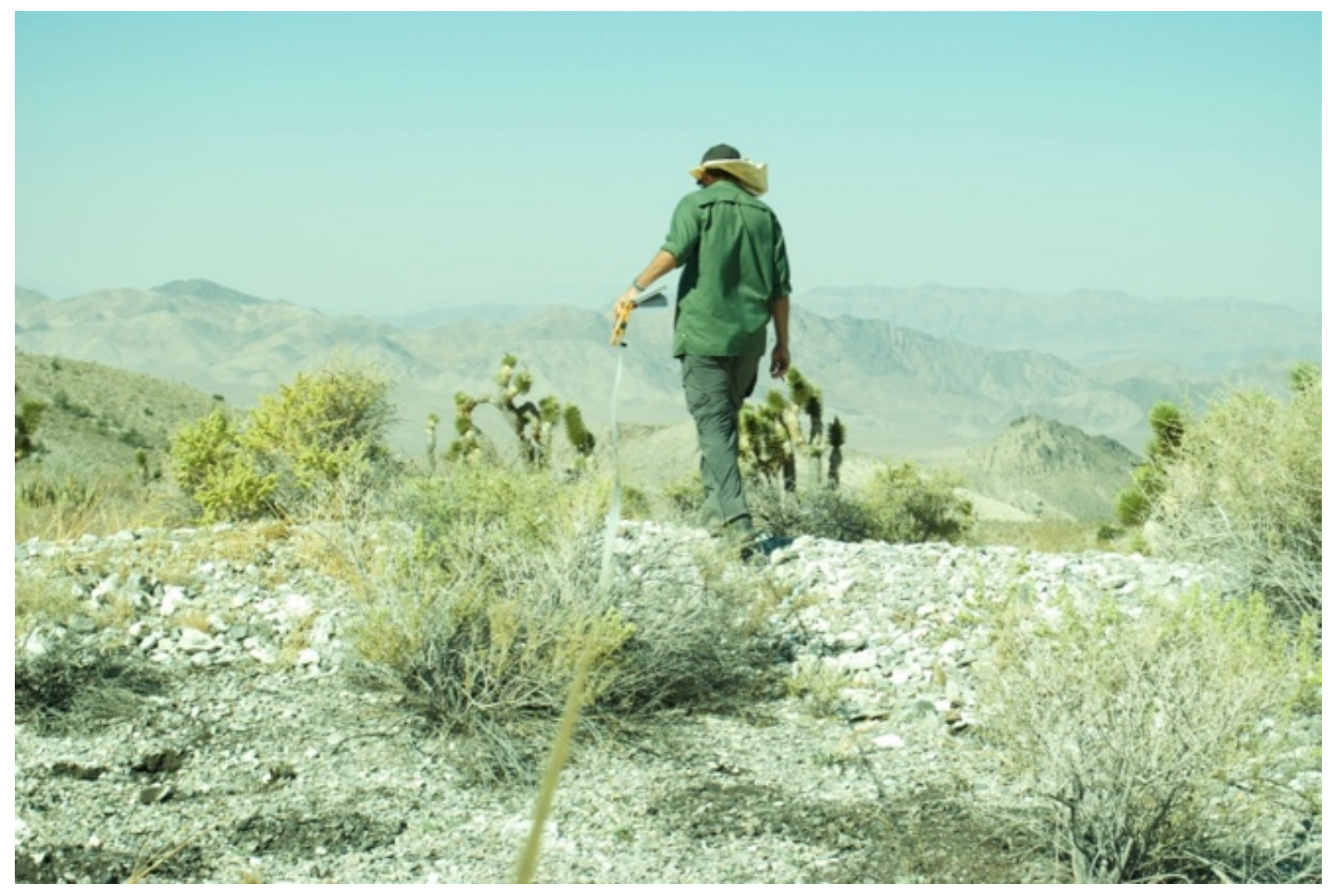

Vegetation Research and Field Survey

Transect surveys provided a simple method to gauge the number of vascular plant species (species richness) around each of the ten springs and provided a rough sketch of species along a spring-upland gradient. Using a transect method adapted from Abella et al. (2014), I walked three transects running perpendicular to the springhead and recorded all native and non-native plant species within $1 \mathrm{~m} \times 1 \mathrm{~m}$ quadrats at $\mathrm{om}, 2 \mathrm{~m}$, and $1 \mathrm{Om}$ along each transect. I 
collected photographs and specimen vouchers to verify identification with a dichotomous key and consulted with an expert in local botany (see Appendix C, List of Vascular Plants Identified during Survey). I compiled and crossreferenced results of these plant surveys with comprehensive studies of Refuge flora by Ackerman et al. (2003) and Charlet et al. (2013), a springs vegetation study by Abella et al. (2014), and historical documentation of native and introduced plants from the DNWR archives (USFWS accessed Oct. 2016). I referenced multiple botanical field guides and manuscripts to aid in identifying plants, obtain information about their ecology, and to compile a list of springs flora (Jepson Flora Project 2016; Nevada Natural Heritage 2016; Charlet et al. 2013; Rhode 2002; Ackerman et al. 2003). Some species were identified to genus only, often due to a lack of flowers or fruiting parts. I employed linear regression and two-sample t-tests to statistically analyze species richness (number of species) at each spring in relation to elevation, disturbance intensity, and mountain range setting. This does not account for the abundance or distribution of species but is a starting point to understand what plants are associated with springs in their developed state and what effect springs have on the local vegetation (Ackerman et al. 2003; Charlet et. al 2013). For botanical field survey results, see Table 13. For a detailed syntheses of Refuge springs introduced plant species, see Appendix D. 


\section{Disturbance Index}

As a means to rank springs according to the number of major observable sources of disturbance that impact them, I created a simple disturbance index framework. I adapted parameters from Nevada Springs Conservation model of spring health based on four key ecological attributes and nine sources of stress (Abele 2011), as well as Fleishman et al. 's (2006) categorization of disturbance used for springs in the Spring Mountains National Recreation Area. Parameters are listed in Table 15 and scored in Table 16. A score of 0-2 sources of disturbance suggested the spring ecosystem may be minimally disturbed; a score of 3-4 indicated a system that is likely moderately disturbed; and a score of 5-6 suggested the spring is probably highly disturbed. The Index does not intend to measure disturbance in absolute terms but offers a relative comparison of springs and a basic starting point to considering the impacts of anthropogenic and natural sources of disturbance on spring ecology.

\section{Study Limitations}

This study describes the historical ecology of springs based on the analysis of, six interviews with USFWS land managers and local experts, 10 plant surveys and archaeological pedestrian surveys in addition to existing botanical and archaeological research from the Refuge, over 80 years of USFWS archival records, and multidisciplinary literature review. Where historical records and reference conditions for Refuge springs were unavailable, I consulted data 
available from comparable springs in the Great Basin/Mojave region to infer historical morphology, hydrology, and habitat. When hypothesizing the drivers of change, a high level of interest in some processes (e.g., climate change) can overshadow alternative explanations for observed patterns (Stein et al. 2010; Vellend et al. 2013). A major challenge within the historical ecology framework is that missing or inconsistent records limit what systematic analysis is possible. For instance, I found it was beyond the scope of this study to conduct thorough spatial and statistical analysis of Refuge archaeology, due to major inconsistencies, omissions, and errors discovered in the state-held archaeological records from the Refuge. This research would be made stronger with the inclusion of paleontological data to better understand the upland springs prior to human habitation, as well as archaeological testing below ground and in roasting pits to gain more information on human activity near springs. Additionally, palynological (pollen) analysis would help create a reference for former springs flora (e.g. Enzel et al. 2003). 


\section{CHAPTER 2. CONTEXT}

\subsection{Aridland Springs Ecology}

Springs are small-scale aquatic systems that occur where groundwater reaches the surface. Under the force of pressure and gravity, groundwater flowing within the confines of subterranean rock layers ("aquifers") emerges through cracks, openings, or loose soil to form a pool, or damp, vegetated areas. More accurately termed GDEs, springs are highly heterogenous and classified according to dozens of variables, mainly comprising: geomorphic conditions, sphere of discharge, flow characteristics, water quality and geochemistry, habitat and biological characteristics, and management aspects. The characteristics of flow, temperature, and water quality are largely determined by hydrogeological setting (Springer et al. 2008). As groundwater dependent ecosystems, springs are shaped and respond to climatic factors playing out near and far. Local patterns and rates of precipitation, temperature, evapotranspiration, and other multiscalar climatic factors are key abiotic components of spring ecosystems (Laczniak et al. 2000). For more detail on pre-human-spring context, see Appendix F. Spring systems are also influenced and shaped by their biotic populations-ranging from algae, to humans-and, less tangibly to Western science, by the water spirit beings long-respected in Nuwu/Nuwuvi tradition. Due to the complex, highly interdisciplinary nature of springs, comprehensive approaches are needed to understand and protect them (Stevens and Meretsky 2008). Below 
I summarize a selection of characteristics of Refuge springs included in this study.

\section{Spring Morphology}

The 10 upland springs surveyed fall under the following three "spheres of discharge", a morphological descriptor of how groundwater emerges at the spring head (Springer et al. 2008; Springs Stewardship Institute n.d.). Table 4 shows the three types of springs included in this study, as designated in the USFWS springs files.

Table 4. The three spring spheres of discharge of upland Desert National Wildlife Refuge springs (adapted from Springer et al. 2008).

\begin{tabular}{|c|c|c|c|}
\hline $\begin{array}{l}\text { Sphere of } \\
\text { discharge }\end{array}$ & Hypocrene & Hillslope & Exposure \\
\hline Description & $\begin{array}{l}\text { A buried spring where } \\
\text { flow does not reach } \\
\text { the surface, typically } \\
\text { due to very low } \\
\text { discharge and high } \\
\text { evaporation or } \\
\text { transpiration. } \\
\text { E.g. Spring } 5\end{array}$ & $\begin{array}{l}\text { Emerges from aquifers } \\
\text { on a hillslope (30-60 } \\
\text { degree slope); often } \\
\text { indistinct or multiple } \\
\text { sources. } \\
\text { E.g. Spring } 2\end{array}$ & $\begin{array}{l}\text { Water is exposed } \\
\text { from an opening in } \\
\text { bedrock } \\
\text { E.g. Spring } 7\end{array}$ \\
\hline
\end{tabular}

\section{Spring flow}

Spring size is generally characterized by discharge volume. In addition to the larger, persistent artesian springs at Corn Creek (33 gallons per hour), the flow rates of the 34 small springs and seeps of Desert NWR may be intermittent or variable. Most of these discharge less than seven gallons per hour (16 ounces/minute); some barely saturate the soil at the spring head (USFWS 
archives), while Spring 1 discharged nearly 20 gallons/hour (42 ounces/minute) during my field visit Oct. 2016.

Persistence is one important qualifier of spring flow. Persistence of the flow of a spring depends on a number of local and regional factors including net basin supply, groundwater recharge, groundwater withdrawal, precipitation and runoff, temperature, geological setting, and vegetation (Grimm et al. 1997). Because springs constitute special discrete habitats with relatively stable conditions, they may allow monitoring of groundwater as expressed through changes in flow rates and spring flora.

\section{Spring biota}

Relative to the biotic communities in the surrounding landscape, springs with regular flow naturally have more stable and resilient communities but are also vulnerable to severe disturbance. From a biogeographical perspective, springs often function as islands of habitat. Aridland springs are typically isolated from other waters and minimally influenced by environmental variability, except for drought and anthropogenic impacts). Aridland springs exert vastly disproportionate impact on adjacent ecosystems and regional ecology compared to non-spring habitats and have been designated as keystone ecosystems. Despite high rates of evaporation in desert settings, a constant groundwater temperature creates a limited, stable habitat at the spring source for adapted species. As a result, spring ecosystems tend to be small, allowing only relatively small populations to survive. 
Thanks to the relative stability of spring systems, the biotas of desert springs often are remnants, left behind as surface water disappears with the expansion of deserts. They are often relicts of wetter times, providing clues to conditions in the distant past (Unmack and Minckley 2008). Like a time-capsule, springs containing paleontological remnants can reveal information about changing climates and ecosystem responses over time. As a result, springs persisting since the end of the Pleistocene Era (approx. 11,700 years ago) served as refugia for species during climatic changes, and often are host to one or more endemic species, which occur nowhere else on earth. For instance, the springs of Ash Meadows NWR, part of the Desert NWR Complex, are home to the highest concentration of endemic species in the United States, harboring nearly 30 endemic species, 12 of which are listed as threatened or endangered (USFWS 2013). The artesian springs at Corn Creek, supplied by the Las Vegas Valley fill aquifer, indicate the presence of wetlands and aquatic biota dating back 40,000 years (Enzel et al. 2003). The endemic Corn Creek pyrg snail (Pyrgulopsis fausta), exists at the larger, lowland springs of Corn Creek at Refuge headquarters. The 34 springs on the Refuge are moderately isolated (1-10km apart).

It is not clear for how long upland DNWR springs have persisted, and there is no documentation of endemic species from the lower flow, upland springs included in this study. They appear to largely depend on seasonal precipitation, which implies that with the present climate their flow rates 
naturally decline in drought and/or dry seasons, making them less favorable to many wetland species and less likely to evolve endemic species (Springer et al. 2008). Other factors that may influence the biodiversity of springs include the nutrient status of spring waters, and effects of groundwater extraction or contamination. Additionally, invasive species may quickly overwhelm and outcompete native spring species.

\section{Spring Vegetation}

An upland spring produces a relative abundance of water which fosters a patch of distinct vegetation and habitat (Charlet et al. 2013). These distinct communities usually occur downhill from the spring source. They may measure as little as a few square meters (e.g. Spring 7 in the Las Vegas Range, and Spring 5 in the Sheep Range), or can support well-developed woodland communities (Sada 2008). Vegetation varies along a gradient with distance from the spring head. Patten et al. (2008), categorizes the spring-upland gradient of Mojave and Great Basin Desert into four segments. These exist along a continuum of communities which are classified as wetlands, wetland/upland transition communities, phreatophytic-upland communities, and upland communities. I characterize each zone in the spring-upland gradient below in Table 5, based on Abella et al. (2014); Patten et al. (2008); and Stevens and Meretsky (2008).

According to this definition, some springs in the study harbored wetland communities, with water-saturated soils, herbaceous species, and wetland plants such as wiregrass (Juncus spp.). Phreatophytic upland communities are not 
directly influenced by surface water but feature some plant that tap into the relatively elevated water table around a spring. Wetlands may dry out and disappear following significant dips in the water table (the uppermost saturated layer of an aquifer). Springs also host alga, aquatic plants, and numerous invertebrates which play an important role in the nutrient cycle.

Springs at higher elevations are generally less invaded by non-native species due to remoteness from human activity and climate extremes (Abella et al. 2014). Even small springs can support aquatic habitat and riparian vegetation zones with greater species diversity, particularly if flows are consistent (Fleishman et al. 2006; Sada and Lutz 2016). Many upland springs at DNWR lack the expected gradient in vegetation and have very limited or absent non-upland habitats. This is believed to be due to reduced discharge and surface flow as a result of their modification, a point made both in interviews with expert Botanist and Restoration Ecologist, as well as Refuge vegetation studies by Abella et al. 2014, and Charlet et al. 2013. Prior to their alteration by settlers, the springs on Desert NWR may have provided some aquatic habitat and supported larger riparian zones with greater species diversity (Ackerman et al. 2003; Brussard et al. 2015). 
Table 5. Spring-upland gradient zones

\begin{tabular}{|l|l|}
\hline Zone & Characteristics \\
\hline Wetland & $\begin{array}{l}\text { Closest to the spring and associated downhill- } \\
\text { flowing water- course, wetlands receive surface flow } \\
\text { or have water-saturated soils and contain obligate } \\
\text { wetland species such as Juncus mexicanus (Stevens } \\
\text { and Meretsky 2008). }\end{array}$ \\
\hline Wetland-Upland transition & $\begin{array}{l}\text { Communities have drier but still moist soils, a } \\
\text { shallow water table, and a mix of herbaceous and } \\
\text { woody species }\end{array}$ \\
\hline Phreatophytic upland & $\begin{array}{l}\text { Not directly influenced by surface water, has a } \\
\text { moderately deep water table and species } \\
\text { composition commonly including Sporobolus } \\
\text { airoides (alkali sacaton) and Atriplex spp. } \\
\text { (saltbush) (Stevens and Meretsky 20o8). }\end{array}$ \\
\hline Upland & $\begin{array}{l}\text { Furthest from the spring and contain non-riparian } \\
\text { communities typical of the surrounding desert } \\
\text { vegetation }\end{array}$ \\
\hline
\end{tabular}

\subsection{Setting: Desert National Wildlife Refuge}

Desert National Wildlife Refuge (DNWR) comprises 1.5 million acres of protected Desert Bighorn sheep habitat (Figure 2). Established in 1936 and managed as proposed wilderness since 1973, it is situated at the transition between the Great Basin and Mojave Deserts in southern Nevada, 30 miles north of Las Vegas. The springs that occur on the Refuge provide critical water for Desert Bighorn sheep and other wildlife, and helped support human populations in the region for the last 11,000 years (USFWS 2009). Nuwu/Nuwuvi have been indigenous to this area since the beginning of time when the world was new 
(Spoon and Arnold 2012). The Department of Defense operates the Nellis Test and Training Range, nearly 850,000-acres of the western part of the Refuge withdrawn from public entry and to which USFWS has limited access. The Sheep Range rises to 9,924 feet, along with the smaller Las Vegas Range (6,943ft), are the two eastern-most of six north-south trending ranges in the Refuge. The Sheep Mountains (like with the neighboring Spring Mountains to the south, a biodiversity hotspot) are considered sky islands-geographically isolated and ecologically diverse-due to their elevational gradients and location at the edge of two deserts (USFS et al.1998). In these arid landscapes, springs are a critical and vulnerable niche for biodiversity because they provide rare water and highly distinct, small-scale, stable environments present across all life zones (Sada 2008; Charlet et al. 2013). 
Figure 2. Location map of the ten springs in this study and administrative boundaries of Desert National Wildlife Refuge.

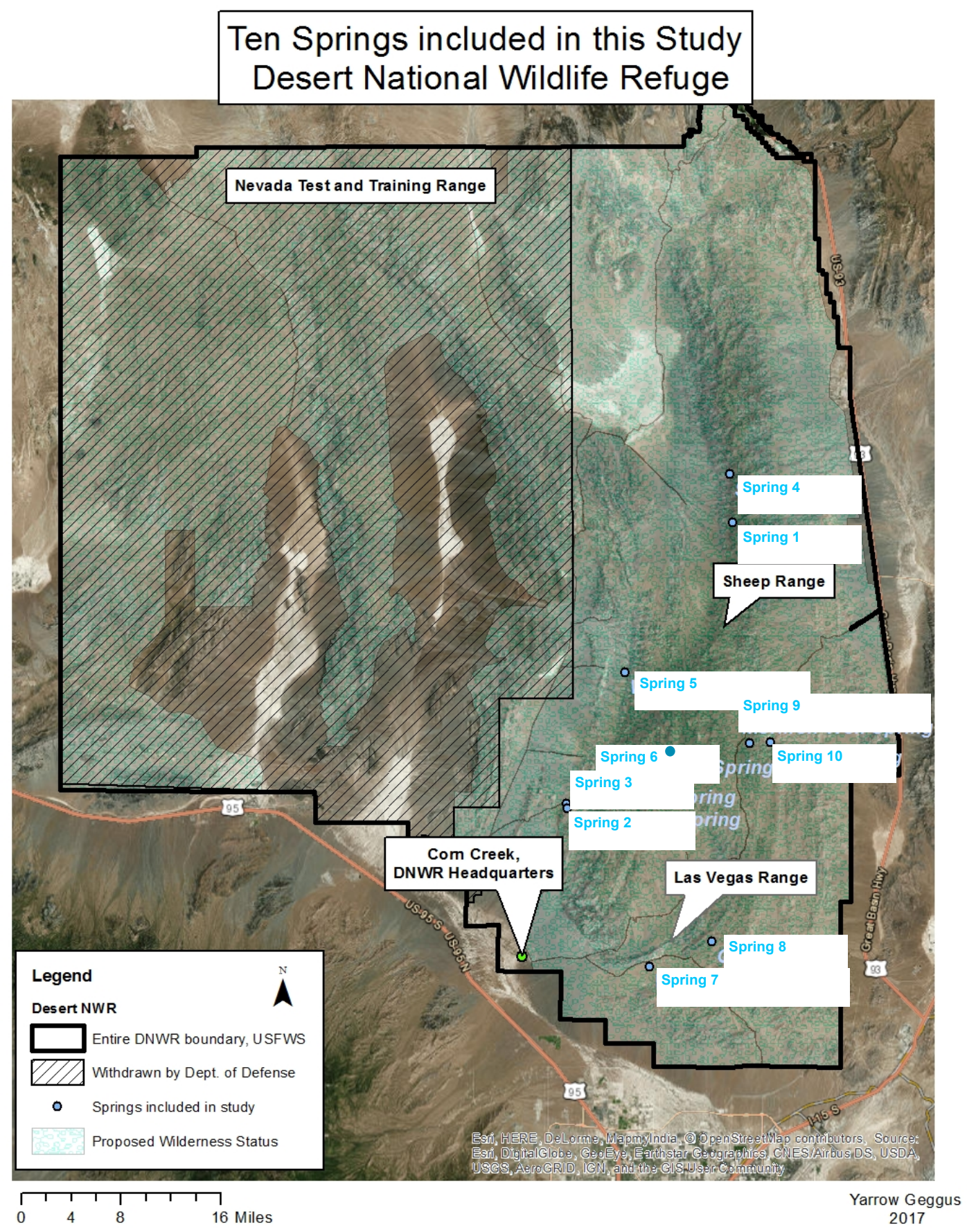


Desert NWR features 39 minor springs and seeps within upland settings and several larger artesian springs at the lower elevation of Corn Creek, Refuge headquarters. The public side of the refuge comprises 22 springs in the Sheep Range and seven in the Las Vegas Range, while the withdrawn portion of the Refuge hosts four in the Pintwater Mountains, and one in the Desert Range (USFWS 2009). Corn Creek is well-studied and listed as a National Register Archaeological District for its significance as a prehistoric archaeological site and historic homestead spanning 5,00o years of human habitation (Roberts et al. 2007). The following research focused on the upland springs/seeps and presents information pertaining to these smaller, at times ephemeral, lesser-studied features.

USFWS archives indicate that the agency holds federal reserved water rights to all of the higher elevation springs dating back to the Refuge's land reservation of 1936, as well as state appropriative water rights. Eleven of the springs (those within the Las Vegas Valley Basin) have adjudicated water rights, which means that the legal rights holder and quantity were decided by a court process, transferring the rights from private owners to USFWS. From the agency's springs files, I noted that thirty-two of the springs have been modified for wildlife use with some form of spring head modification and/or piping to troughs or tanks. Red Ram and Cherry Spring are the only springs that remain untapped/undeveloped. In addition to these natural water sources, there are 29 human-made rainwater catchments (known as guzzlers) spread across the seven 
mountain ranges to supplement water and expand habitat for Desert bighorn sheep (USFWS 2013).

Image 2. Bighorn sheep herd near Spring 3, Sheep Mountains. Credit: Spencer Lodge.

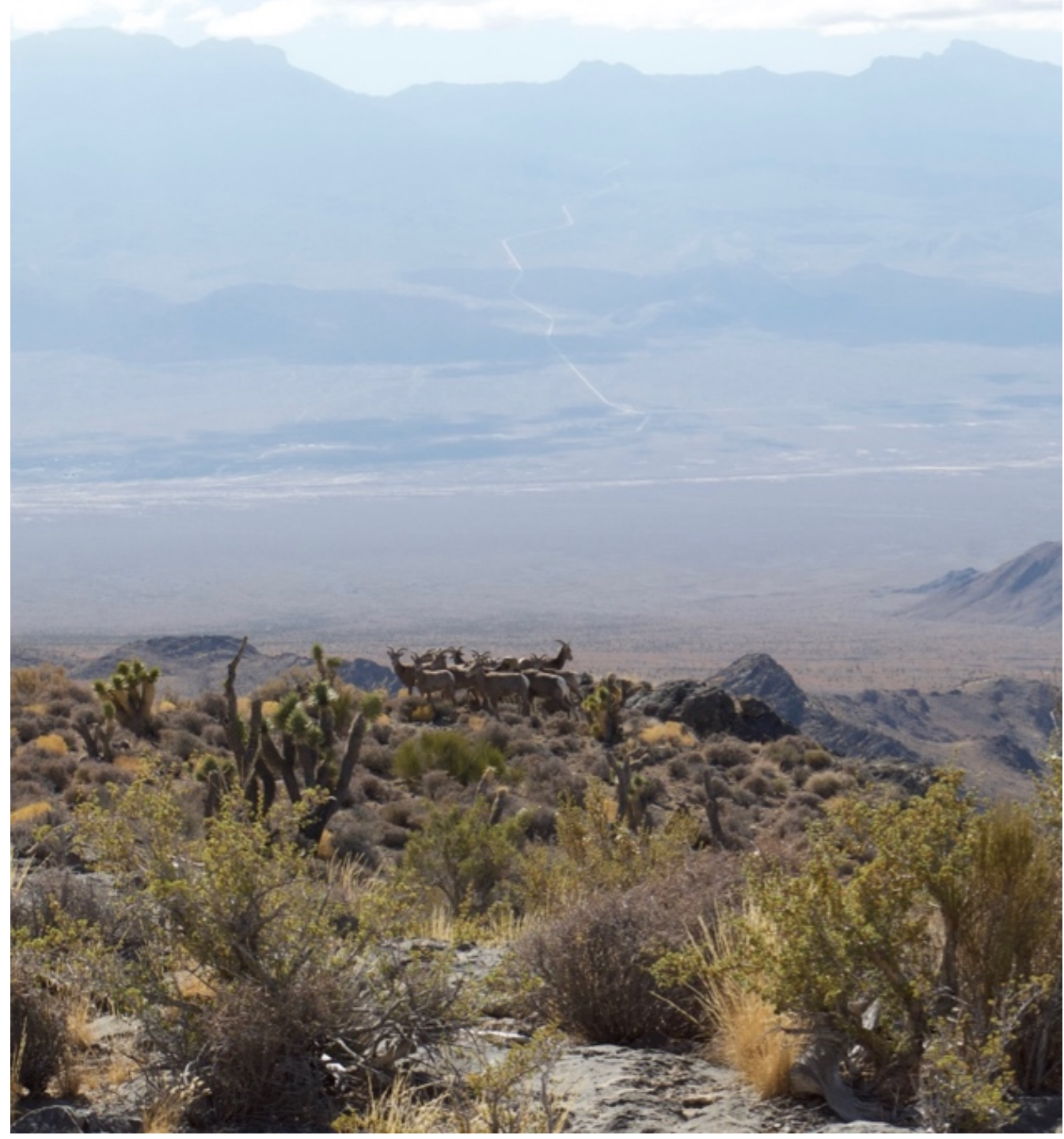




\section{Hydrogeology of Desert National Wildlife Refuge}

The climate and geologic assemblage of aquifers play fundamental roles in the recharge and discharge relations within a groundwater system (Moreo et al. 2014). For additional details, I situate springs in their geological and global climate context in Appendix F. The Refuge's groundwater originates mostly from local and regional winter precipitation that falls at high elevation and percolates through soil and rock. The Sheep Range receives up to fifteen inches of precipitation a year, mostly as snow, while the valleys of the Refuge receive an average of four inches of rain annually. It is estimated that up to 15 percent of precipitation at the highest elevations of the Sheep Range infiltrates aquifers and recharges groundwater (Huntington, 2010; Moreo et al. 2014).

The Refuge landmass comprises a complex amalgam that includes three types of aquifers, listed in order of their occurrence at increasing depth below the surface: perched, basin-fill, and regional carbonate. Springs in my study are believed to be "perched" springs, meaning that they are fed by local, confined aquifers located above the regional carbonate-rock aquifer, and are more reliant upon localized precipitation. Their discharges are seasonally variable, with lows highest during or immediately after spring runoff and storm events and then diminishing or ceasing in late summer or early fall (USFWS 2013). Determining the extent and hydraulic nature of the local perched aquifers that supply the Refuge springs was beyond the scope of this study. While the perched springs of 
the Sheep Mountains are isolated from the regional carbonate aquifer, the aquifer of origin and connectivity of springs at the base of the Las Vegas Mountains are less clear (Naff et al. 1974; Huntington 2010; Moreo et al. 2014).

Basin-fill aquifers made of alluvium deposits underlie the valley bottoms, deep carbonate aquifers are overlain by basin- fill aquifers made of loose alluvium deposits. The Las Vegas Valley aquifer (see Figure 3) is a local basin-fill aquifer that stretches into the southwestern parts of the Refuge; it overlies the bedrock between the Sheep and Las Vegas Ranges and fills the depressions between the limestone outcrops of Las Vegas Range (Fiero 1975). Precipitation on the Sheep and Spring Mountain Ranges accounts for 95\% of groundwater recharge to the Las Vegas Valley basin- fill aquifer (Huntington 2010).

The regional aquifers that underlie the Refuge are the Death Valley Flow system (also known as the Ash Meadows Flow System) and the Colorado River Flow System (also known as the White River Flow System). These hold enormous stores of water and require thousands of years to recharge; groundwater may spend ten thousand years moving through these aquifers, hence earning the name "fossil water" (Lacziak et al. 1999). This essentially qualifies the groundwater as a non-renewable resource, and yet it continues to be overdrafted with no sign of abatement. The artesian springs of Corn Creek at DNWR headquarters originate from geologic faults that disrupt both the deep carbonate aquifer and the shallow basin- fill aquifer, resulting in the emergence of pressurized water at the fault line (Fiero 1975; USGS n.d.). 
Figure 3. Groundwater flow regions and basins of DNWR springs

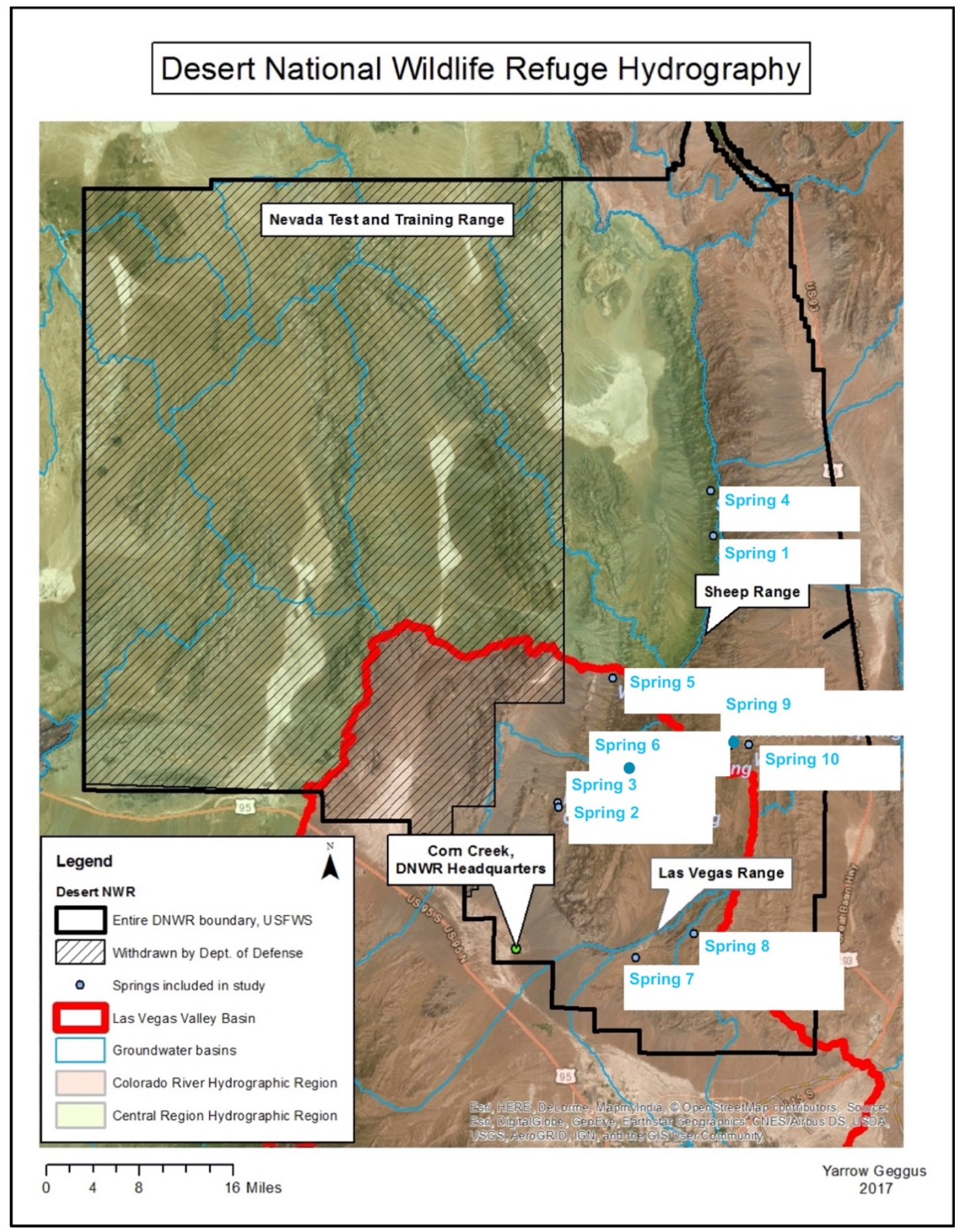


At least two of the Refuge springs I surveyed lie within the extent of the Las Vegas Valley basin-fill aquifer: Spring 8 and Spring 7 (see Figures 4 and 5). Their minimal yield suggest that they originate from a shallow, or perched aquifer within the basin-fill alluvium, but the extent or connectivity between these are not known. Further, the high transmissivity of carbonate rock allows the movement of groundwater both vertically (primarily downward with gravity) and laterally between surface basin-fill and regional aquifers. Groundwater also flows upward from the Colorado River Flow System into the overlying Las Vegas Valley basin-fill aquifer. As a result, distant groundwater extraction from the regional aquifer may have an even greater impact on local springs that overlie these (Naff et al. 1974; Winograd et al. 1975). Figure 6 below portrays the complex directional flow of groundwater among basins within DNWR. This map indicates lateral flow from the Las Vegas Valley Basin toward the seven springs in the Las Vegas Range. These may be affected by the drastically lowered water table of the basin-fill drainage (Pavelko et al. 1999). Certain Las Vegas Range springs lie within the severely over-drafted basin-fill deposits of the Las Vegas Valley and are all underlain by the threatened Colorado River Flow System. 
Figure 4. (below, left) Geological Map of the Las Vegas Valley: Spring 8 and Spring 7 are located above the Las Vegas Valley Basin-Fill aquifer (adapted from Huntington 2010).

Figure 5. (below, right). Detail of Geological Map of the Las Vegas Valley: Spring 8 and Spring 7 are located above the Las Vegas Valley Basin-Fill aquifer (adapted from Huntington 2010).

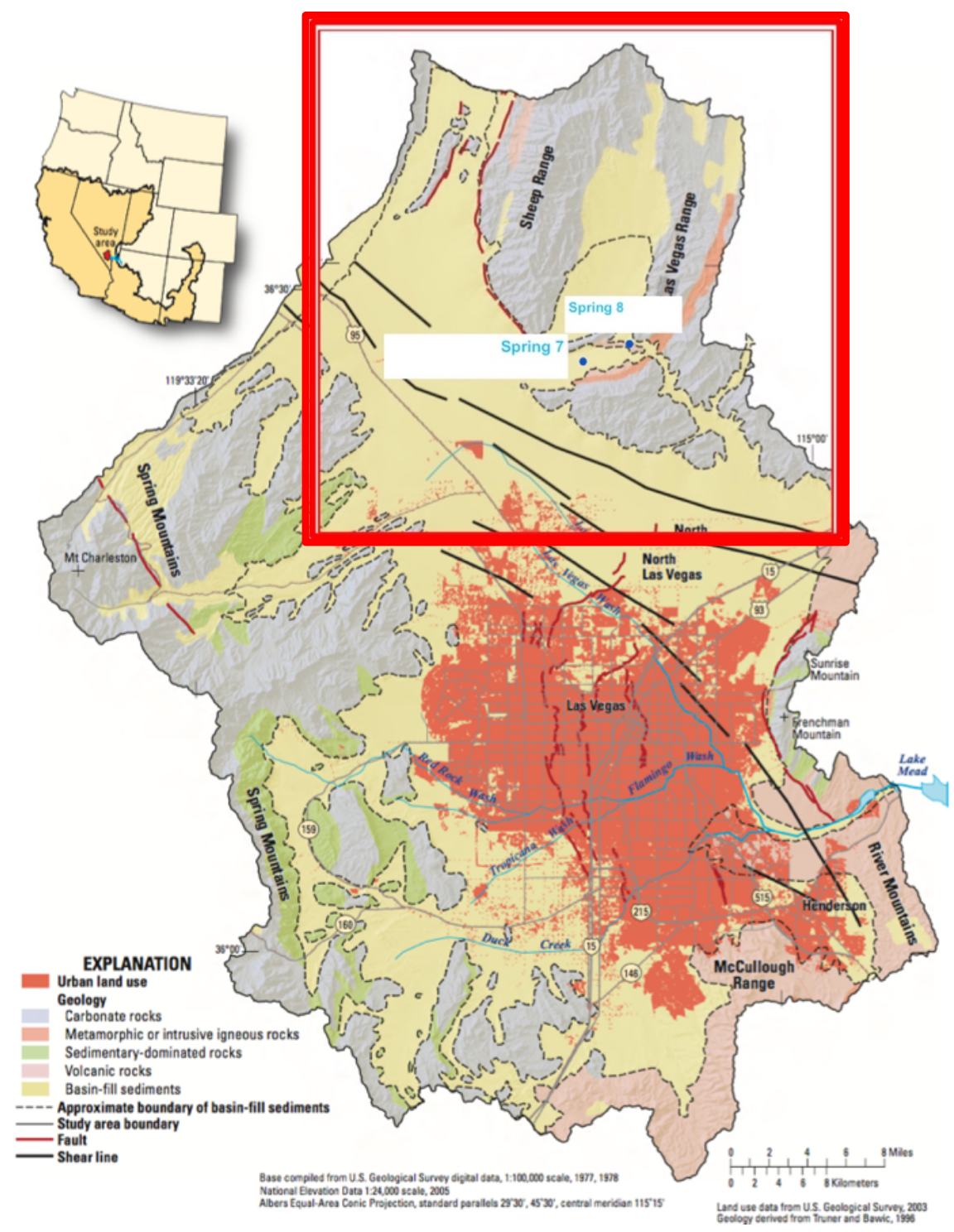


Figure 6. Complex directional flows of groundwater among basins and within the Desert National Wildlife Refuge boundary. The southern end of Las Vegas Range is an area that receives influx from the Las Vegas Valley basin, potentially implicating these springs in groundwater withdrawal (USFWS 2009).

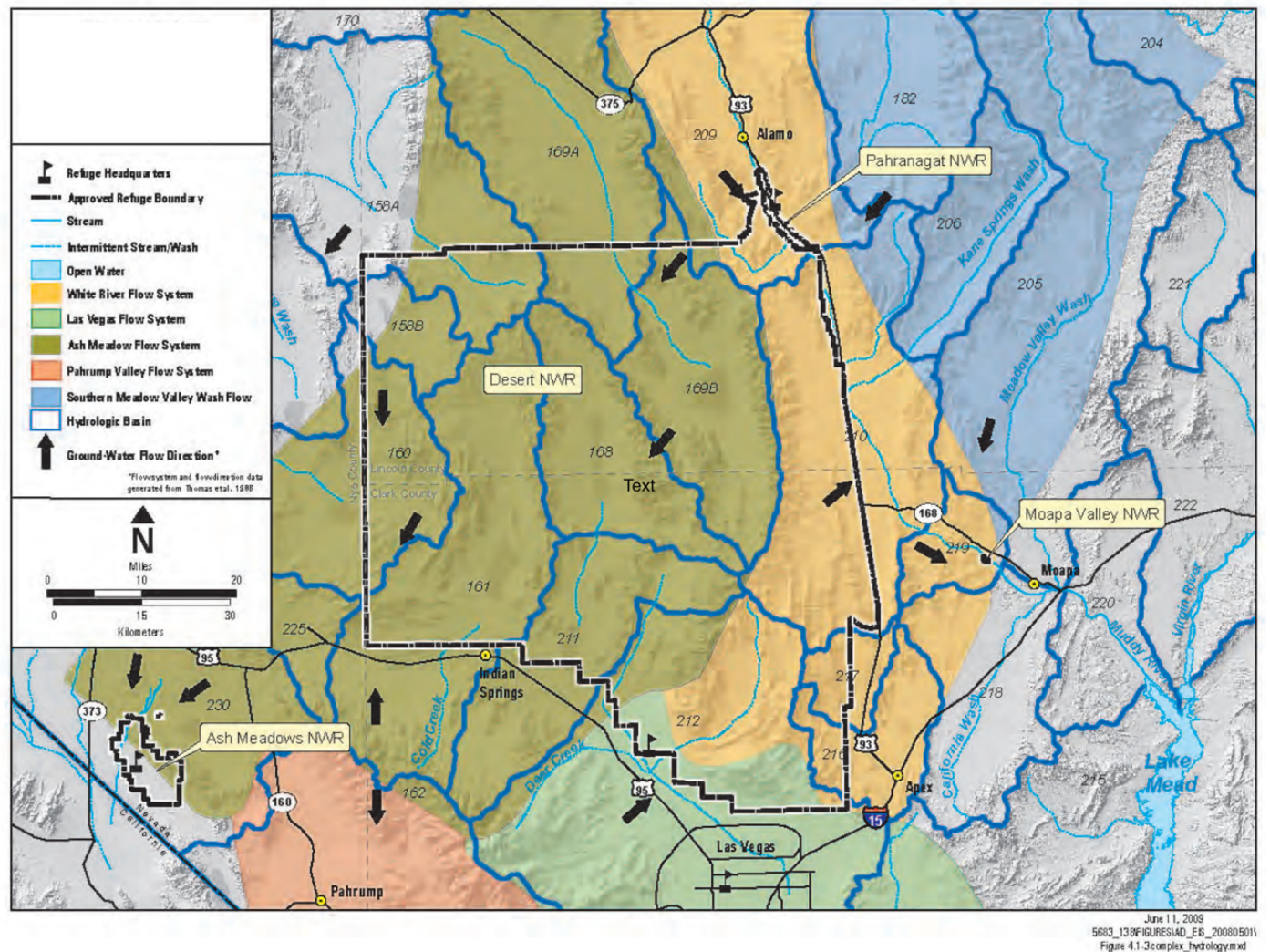

Legal Regulation of Groundwater

In the United States, individual states developed groundwater laws (Cech 2005 p. 235). In Nevada, the doctrine of Prior Appropriation forms the basis of water policy. Before this, Nuwu/Nuwuvi customs around spring water included a system of ownership based on kinship and family occupation near springs, although these customs were not monolithic and changed over time (Fowler 2012b.; Spoon et al. 2012). Since 1908, all above- and below-ground water within 
the boundaries of the Nevada belongs to the public. It is subject to appropriation for beneficial uses as filed with the State Engineer, head of the Nevada Division of Water Resources. Prior appropriation, also known as "first in time, first in right", grants priority to senior water rights to White settler-colonialists for extractive uses, even as new uses for water are allocated (SNWA 2015b). As a tool of SettlerColonial conquest, Prior Appropriation dispossessed Native Americans from water in their territories (Berry and Jackson 2008; Curley 2019). In the West, where water resources are scarce, water users must continue to demonstrate the actual beneficial use of water, or lose the rights (Cech 2005). Each of Nevada's 256 hydrographic basins (drainage areas) are considered a separate source of water with a distinct perennial yield (Nevada Division of Water Resources 2014). DNWR comprises thirteen hydrographic basins, listed in Table 6. below.

Table 6. The 13 hydrographic basins of Desert National Wildlife Refuge (Source: NDWR 2014)

\begin{tabular}{|c|c|c|c|}
\hline \multicolumn{2}{|c|}{$\begin{array}{l}\text { Death Valley System } \\
\text { (aka Ash Meadows Flow System) }\end{array}$} & \multicolumn{2}{|c|}{$\begin{array}{l}\text { Colorado River System } \\
\text { (aka White River Flow } \\
\text { System) }\end{array}$} \\
\hline Basin \# & Name & Basin \# & Name \\
\hline $158 \mathrm{a}$ & Emigrant Valley (Groom Lake): & 209 & Pahranagat Valley \\
\hline $158 b$ & Emigrant Valley (Papoose Lake); & 210 & Coyote Springs Valley \\
\hline 160 & Frenchman Flat & 212 & Las Vegas Valley \\
\hline 161 & Indian Springs Valley & 217 & Hidden Valley (North) \\
\hline 168 & Three Lakes Valley & 216 & Garnet Valley \\
\hline $169 a$ & Tikapoo Valley (Northern) & & \\
\hline $169 b$ & Tikapoo Valley (Southern) & & \\
\hline 211 & Three Lakes Valley (Southern) & & \\
\hline
\end{tabular}


Approximately 45 basins in Nevada are over-appropriated, which means that more groundwater is allocated for use than is available. The overappropriation of basins and separate approach to surface and groundwater supplies are major issues of concern for the future availability of groundwater in the region (Pavelko et al. 1991). Figure 7 shows that five springs in this study lie within three of those over-appropriated basins listed below in Table 7 (SNWA 2015b, NDWR 2014).

Table 7. Three over-appropriated sub-basins located within Desert National Wildlife Refuge (Source: SNWA 2015b, NDWR 2014).

\begin{tabular}{|l|l|l|l|}
\hline $\begin{array}{l}\text { Hydrographic } \\
\text { Region }\end{array}$ & $\begin{array}{l}\text { Sub-Basin } \\
\text { Name \& Number }\end{array}$ & $\begin{array}{l}\text { Perennial } \\
\text { Yield (Acre- } \\
\text { feet/year) }\end{array}$ & $\begin{array}{l}\text { Appropriated } \\
\text { (Acre- } \\
\text { feet/year) }\end{array}$ \\
\hline $\begin{array}{l}\text { Colorado River Basin } \\
\text { Region }\end{array}$ & $\begin{array}{l}\text { Las Vegas Valley \#212 } \\
\text { (Part of southeast DNWR) }\end{array}$ & 25,000 & 88,500 \\
\hline $\begin{array}{l}\text { Colorado River Basin } \\
\text { Region }\end{array}$ & $\begin{array}{l}\text { Three Lakes Valley \#168 } \\
\text { (Part of western DNWR and } \\
\text { Nellis Air Force Base) }\end{array}$ & 3,700 & 4,500 \\
\hline $\begin{array}{l}\text { Death Valley Flow } \\
\text { System (Central } \\
\text { Region) }\end{array}$ & $\begin{array}{l}\text { Indian Springs Valley \#161 } \\
\text { (Part of DNWR and Nellis } \\
\text { Air Force Base) }\end{array}$ & 500 & 1,390 \\
\hline
\end{tabular}


Figure 7. Over-appropriated basins within Desert National Wildlife Refuge

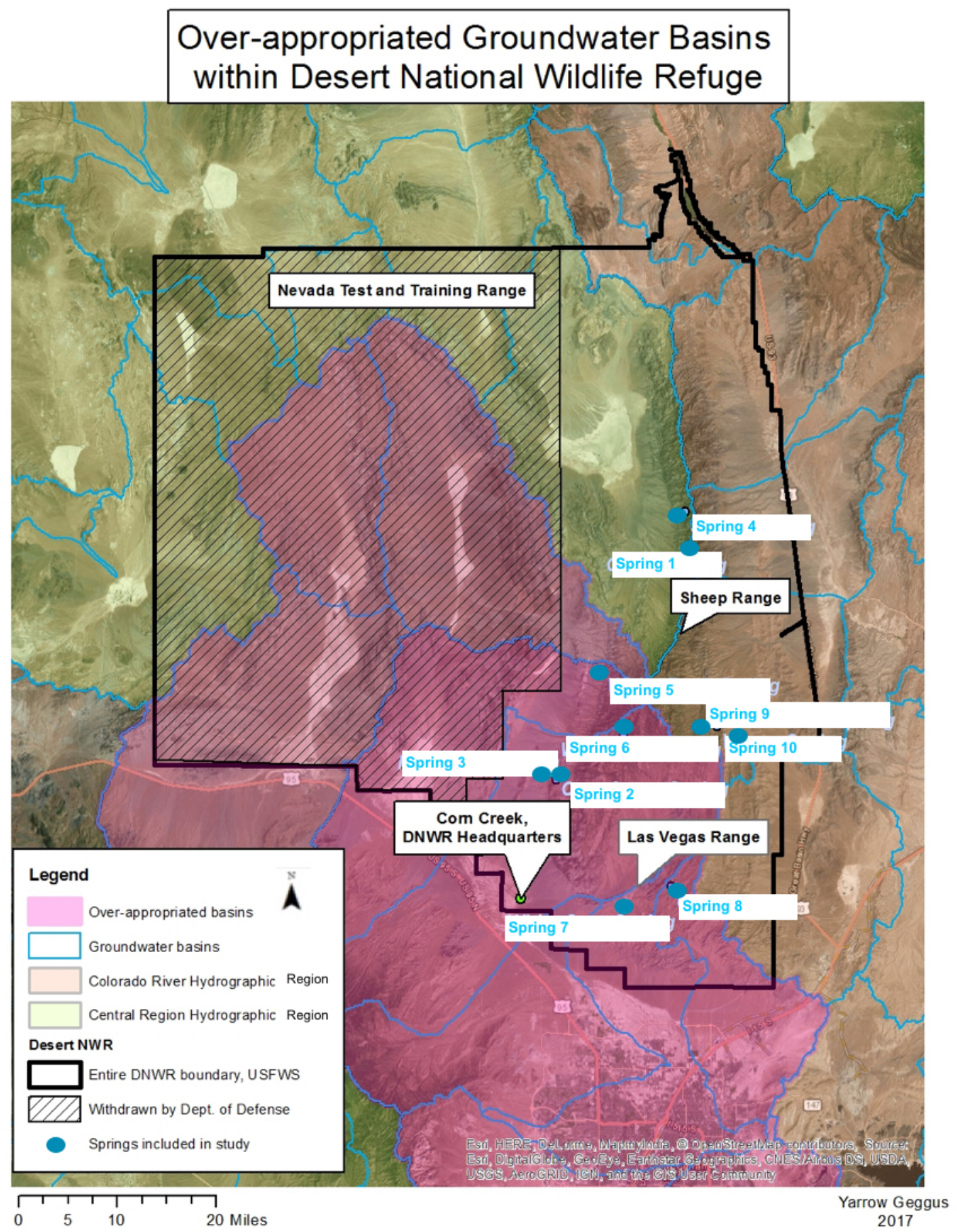




\section{Chapter 3. RESULTS}

The following three-part chapter consists of a chronological inquiry into the human-spring relationships over time. I illustrate that Indigenous and settler societies of the Southern Great Basin/Mojave Desert have distinct, dynamic relationships with spring-fed habitats. I examine the intersection of climatic, socio-cultural, and political-economic drivers culminating in differing lifeways, practices, and perspectives of managing these habitats (Wendel 2012; Spoon 2013). I argue that the changes in scale and intensity of human influence within the springs landscape can be classified across three broad "eras" (Table 3) which encompass human relationships with upland (mountain) springs from 1) Nuwu/Nuwuvi Era of activity before European contact ( 11,500 BCE- 1850 CE), 2) the Euro-American settler period ( 1850-1936), and lastly, the current period of 3) federal management as a U.S. Fish and Wildlife Refuge (1936-present). For the purpose of this analysis, I generalize each time period according to the dominant relationships; however, they are not mutually exclusive and each regime overlaps and layers upon the preceding one.

Among the lines of evidence informing this historical ecology are records of spring use and management, field surveys of ecological condition and disturbance, plant species richness surveys, archaeology surveys, and the social constructs of nature examined through the lens of cultural anthropology and environmental history. Of the many factors influencing spring ecological change within each era, I address the geoclimatic backdrop (the "where/when"); the 
human-mediated drivers" including worldview, social constructions of nature, political and economic drivers (the "why); the spring use and management practices (the "how"); and the inferred spring ecological conditions and anthropogenic change they produce (the "what?”).

Looking through the lens of water provides evidence of the particular ideological motivations, institutional policies, and encounters that drove spring histories and which, in many instances, continue to underpin contemporary situations (Berry et al. 2017). I argue that interpreting these factors via multiple methods and lines of evidence contributes to a more multidimensional understanding of springs and their relationship to humans over time.

Archaeology provides a glimpse into the history of occupation and resource use on the Refuge across millennia (Roberts et al. 2007; Lodge 2016). Although only a small portion of the DNWR landscape has been surveyed for archaeological resources, I found approximately 450 records of pre-contact sites and several historic sites within the Refuge (NVCRIS, accessed April 2017). Through a combination of field surveys and research into existing archaeological records, I found 98 archaeological sites or isolates and documented 14 previously unrecorded sites, including lithic scatters, roasting pits, and pre-contact and historic pictographs. I found significantly more records of archaeological material located within o-0.5 miles of each spring than 0.6-1.5 miles ( $\mathrm{p}<0.05$; two tailed $\mathrm{t}-$ test assuming unequal variance.) On average, I found records of 6.1 archaeological sites or isolated artifacts/features within 0.5 miles of each spring, 
and only 1.1 record between 0.5-1.5 miles of each spring. Removing Spring 9 from the sample results in an even greater significance $(\mathrm{p}<0.001)$, since it is one of the only areas that has been extensively surveyed before. This material analysis contributes a long-term perspective to larger issues of water use in arid lands, Indigenous and settler ecologies, and helps form a present baseline for springs that is cognizant of cultural history.

The traditional ecological knowledge highlighted in contemporary ethnographies with tribal members offers an alternative, culturally-grounded perspective on the crisis of groundwater depletion as a problem of human relational imbalance and neglect of springs and environment. This supports a case for greater Nuwu/Nuwuvi interaction with the land and springs in order to restore balance across the landscape. I argue that coinciding global, anthropogenic climate changes likely magnified the impact of regional socialenvironmental disruption and local manipulation of springs following EuroAmerican settlement. Settler-colonial concepts of humans as separate from nature and a utilitarian value of springs underscore the systematic development of springs and legally mandated appropriation for beneficial use (Welden 2003). These practices created lasting, extant changes and degradation to the ecological form and functioning of these groundwater dependent ecosystems. My findings support that significant ecological disturbance occurred following Euro-American settlement and development of springs, and that springs remain in an impaired state. 
In addition to providing a more comprehensive understanding of springs over time, this work reveals many gaps needing further research. The gaps include the detailed study of the springs' ecological characteristics and their natural range of variability within the extreme limits of different climatic and anthropogenic regimes (Swetnam et al. 1999). Additionally, more research about the Settler impact upon the springs and in comparison to other water sources, both across the American West and globally, would elucidate this important segment of their historical ecology. Finally, potential spring restoration projects can be defined with further research, consultation and leadership from tribes, and experimentation and Nuwu/Nuwuvi-USFWS collaborations.

\subsection{Nuwu/Nuwuvi pre-Contact Era, 11,500 BCE-1850 CE}

This chapter discusses evidence from the archaeological and ethnographic record for a seasonally migratory, Nuwu/Nuwuvi way of life that revolved around springs, the main sources of water across the arid territory. I argue that the Nuwu/Nuwuvi kin-centric, mutualistic relationship to nature supported an ethic of moderated use and small-scale disturbance through a body of practices spanning physical and spiritual care. This may have fostered diverse and resilient spring systems. This lens portrays the desert landscape (mistakenly deemed by some settlers as a void), as an animated, culturally imbued homeland dotted with spirited springs that anchor the seasonal gathering places for pine nut, agave, 
bighorn sheep, and other important plant and animal kin, and are the landmarks of Nuwu/Nuwuvi songs and stories transmitting cultural and ecological knowledge across generations. This research provides a look into how Nuwu/Nuwuvi likely adapted to drought times by respecting and rationing use of springs. While evidence of spring species compositions from pre-Contact times is lacking at this time, other studies from the Southwest indicate that Indigenous practices generated more robust riparian biodiversity (Nabhan 2008). It also reemphasizes Nuwu/Nuwuvi belonging to the springs landscape and the inextricable link forged between them and springs over the last 11,00o years of documented human presence. The traditional ecological knowledge highlighted in contemporary ethnographies with tribal members offers an alternative, culturally-grounded perspective on the crisis of groundwater depletion as a problem of human relational imbalance and neglect of springs and environment. This supports a case for greater Nuwu/Nuwuvi interaction with the land and springs in order to restore balance across the landscape.

\section{Nuwu/Nuwuvi Background}

Nuwu/Nuwuvi (Southern Paiute) are a Numic speaking group whose ancestral lands within the southern Great Basin/Mojave Desert span parts of present-day Nevada, Utah, California, and Arizona, where they have lived since time immemorial. Oral history describes Nuvagantu (Mount Charleston, located 
in the Spring Mountains) as their creation place, which is located 20 miles from the Desert NWR across the Las Vegas Valley. Nuwu/Nuwuvi tradition states that they occupied this landscape since the waters receded from Nuvagantu and Coyote distributed the seven Nuwu/Nuwuvi tribes upon the landscape (Spoon and Arnold 2012). The earliest Indigenous archaeological evidence in this area dates back to over 11,00o years ago (Roberts and Ahlstrom 2012). I draw from contemporary (Spoon and Arnold 2012; Deur and Confer 2012; Wendel 2014; Lefler 2014) and contact-era ethnographies for data about Nuwu/Nuwuvi relationship to springs (e.g. Kelly and Fowler 1986; Kelly 1971; Stewart 1942; Fowler 2012a. 2012b; Fowler 2002; Fowler and Fowler 1990). I assume that some of this Indigenous Ecological Knowledge (IEK) is cumulative in nature (Berkes et. al. 2000), but acknowledge that it cannot encompass the variation of Nuwu/Nuwuvi ecological knowledge and practices that occurred across millennia of adaptive existence within this landscape.

Nuwu/Nuwuvi, Springs and Subsistence Lifeways

Prior to European arrival, Nuwu/Nuwuvi lived highly mobile subsistence lifeways centered around the water sources of springs. While maintaining semipermanent agricultural settlements around the constant water sources of larger, lowland springs of their territories, Nuwu/Nuwuvi utilized a constellation of seasonal plant and animal resource sites located between 2,oooft and 8,oooft. Traditional migrations included annual rounds between high-elevation piñon 
groves in the fall, intermediate elevation agave gathering sites in the spring and summer, and lowland riparian willow and mesquite patches in the summer. Anthropologist Isabel Kelly, who conducted the most extensive primary ethnographic documentation of Nuwu/Nuwuvi lifeways during the early $20^{\text {th }}$ century, recorded that family groups and bands maintained claims to the particular groves and patches they seasonally returned to. Isabel Kelly reports that family groups inherited springs that they camped at in rotation (1971). Several sources note that resource propriety was flexible, however, allowing visits from neighboring groups, especially at productive resource sites at the margins of territories (Kelly and Fowler 1986: 380; Stewart 1942). This cooperative political ethic, especially documented between Nuwu/Nuwuvi and neighboring Newe (Western Shoshone) tribes, as well as with the numerous other tribes along the Colorado River, helped to mitigate the impact of potential lean yields in parts of one's territory and allowed for overabundant resources to be distributed during mast years. At Ash Meadows, a cluster of lowland springs and major regional permanent water source located 70 miles from Corn Creek DNWR, this formed the basis of certain Nuwu/Nuwuvi and Newe social integration and mixed occupation of springs (Kelly and Fowler 1986: 380; Kelly 1971; Stewart 1942). This represents a snap-shot in time and Nuwu/Nuwuvi systems of proprietorship were likely complex and changed over time. This flexible system of resource use and stewardship described in the ethnography reportedly clashed with EuroAmerican concepts of land ownership, and posed a challenge to the efforts of 
settlers and anthropologists to delimit territorial claims and groups (Deur and Confer 2012; Steward 1938

Throughout time, Nuwu/Nuwuvi interacted with springs from a kincentric worldview that grounded in an ethic of respect, reciprocity, and maintaining balance. Organized into small bands or family groups that occupied and shared partially overlapping territories, the highly mobile, subsistence-based Nuwu/Nuwuvi economy and social structure likely entailed ecological disturbances that were small in scale, temporary, and possibly beneficial to biodiversity. The biogeography of the region-- a broad elevation gradient creating habitat variation, along with the absence of surface water-- made upland springs particularly important centers of resource procurement and social activity. Ethnographic accounts and archaeological records indicate that Nuwu/Nuwuvi utilized the more minor, upland springs during seasonal migrations and while camping to gather and process seasonal foods, notably pine nuts, and agave. Springs provided Nuwu/Nuwuvi with drinking water and created the habitat for a number of plant and animal species resources they depended upon for survival in the mountains. To facilitate the collection of drinking water at smaller springs and seeps, Indigenous peoples created hand-dug pools or wells at the spring source, also known as qanat (Sada and Pohlmann 2002; Fowler 2012; Spoon et al. 2013). Nuwu/Nuwuvi set up camps in proximity to springs but at a distance from the source, presumably to respect and minimize impact on the spring. 
Overtime, natural processes and subsequent developments by settlers erased direct evidence of these pre-Contact spring alterations and use (NVSHPO 2016).

Harvest events continue to serve as important social occasions for large groups, particularly during the processing of agaves and yucca, the first foods to become available in the spring, as well as the gathering of pine nuts in the fall (Lodge 2016; Fowler 2012a and 2012b; Spoon and Arnold 2012). Agave (Agave utahensis) was a staple second only to pine nuts, located at intermediate to lower elevations, and closer to winter village sites. Some archaeologists even suggest that agave abundance in the environment is a predictor of archaeological resources such as roasting pits, and may be a good predictor of human occupation generally due to their high level of cultural significance among the Southern Paiute and neighboring tribes (e.g. Shutler and Shutler 1962, in Deur and Confer 2012). 
Image 3. Large roasting pit at mouth of Spring 4 canyon, in an agave abundant area

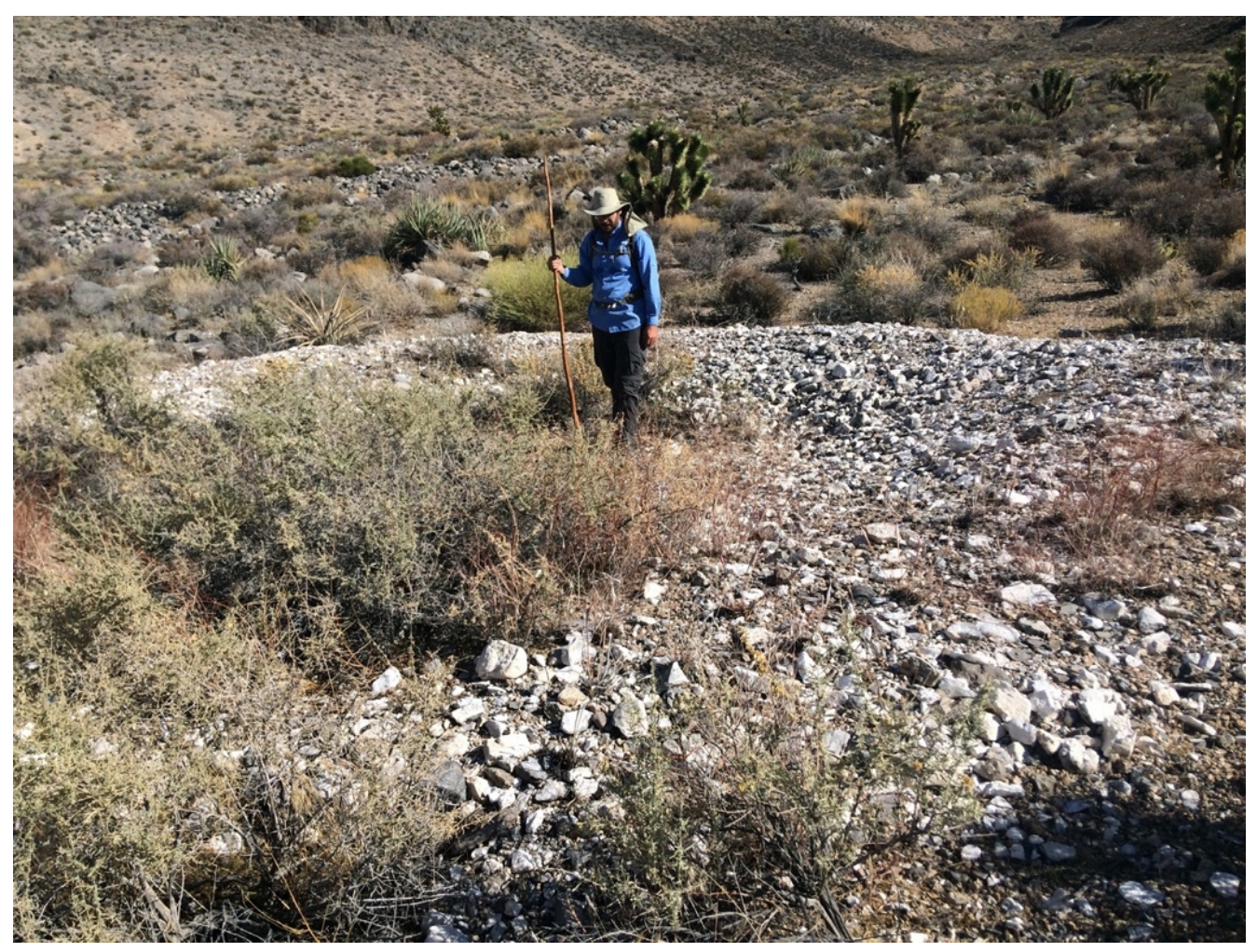

Nuwu/Nuwuvi and Spring Disturbance

Studies show that that pre-Contact manipulation of spring environments by Indigenous peoples creates positive effects on biodiversity by increasing heterogeneity through disturbance (Alcorn 1981; Nabhan 2008; Maffi and Woodley 2010; Gadgil et al. 1993). While I did not locate information specific to pre-Contact Era plant tending at smaller, upland springs and seeps in the Sheep and Las Vegas Range, I did gather from the literature that the ancient, widespread practices Nuwu/Nuwuvi used around other springs engendered lowlevels of disturbance that favor a greater variety of habitats and conditions and 
more diverse ecosystems. Practices such as regular burning, mosaic gardening, irrigating, and transplanting (Spoon 2012b; Spoon et al 2015; Fowler 2012b) encouraged the growth of edible, medicinal, and other culturally important plants (Fowler and Fowler 1990; Ma and Woodley 2010). Watercress (Nasturtium officionale) is one such aquatic food plant that Nuwu/Nuwuvi managed and transplanted from one spring to another (Spoon et al. 2013). Common springs plants such as sedges, rushes, and cattails are popular materials for basketry and other traditional crafts. Willow, mesquite, and cottonwood are also of great material importance for crafts, structures, and firewood and may grow in the vicinity of springs where the water table is consistently high enough (Abella 2014; Deur and Confer 2012).

Ethnographic sources describe agricultural practices including irrigation, transplanting, and patch burning around larger, perennial, lowland springs such as at Corn Creek and nearby Ash Meadows (Fowler 2012b; Spoon et al. 2012c). Nuwu/Nuwuvi grew several types of squash, beans, and corn in addition to gathering numerous wild plants. Gardens were generally small and cultivated by both men and women, with elders likely staying behind during seasonal migratory harvests. People preferred to plant close to a spring brook in damp soil, but if they could not, they directed water to the crops. Planting was done with a pointed digging stick also used for weeding. Crops were stored in pots (corn), brush structures (strips of dried squash) or buckskin bags or pots (beans) (Steward 1938; Fowler 2012b). Nuwuvi returned to spring camps seasonally; it is 
possible that they tended the surrounding vegetation as part of spring management and encouraged the growth of plants they needed, such as through transplanting and periodic burning. Subsurface soil testing and other methods, such as pollen or pack rat midden analysis, could yield information about potential anthropogenic management and vegetation assemblages around springs (Stevens and Meretsky 2008; Egan and Howell 2001, Madsen et al. 2001).

\section{Pre-Contact Archaeology and Springs}

Nuwu/Nuwuvi continue to thrive in their ancestral homeland. In addition to rich, contemporary ethnographies and historical ethnographies, the archaeological record contributes physical traces of the activities that occurred around springs alongside spring management practices before contact (see Spoon et al. 2012a; Spoon et al.2012c; Fowler 2012b; Fowler 2002; Fowler and Fowler 1990). The total 98 archaeological sites and features recorded substantiates the cultural significance of springs to both Indigenous and Settler communities. The 60 Indigenous pre-Contact artifacts and features recorded (Table 8) fall in fall into seven primary categories, listed in Table 9. 
Table 8. Summary of springs archaeology

\begin{tabular}{|c|c|c|c|c|c|c|c|c|c|}
\hline & \begin{tabular}{|l|} 
Total \\
sites
\end{tabular} & $\begin{array}{l}\text { Pre- } \\
\text { Contact } \\
\text { sites } \\
\end{array}$ & $\begin{array}{l}\text { Historical } \\
\text { sites }\end{array}$ & $\begin{array}{l}\text { Mean } \\
\text { pre-Contact } \\
\text { sites/spring }\end{array}$ & $\begin{array}{l}\text { Mean } \\
\text { historical } \\
\text { sites/spring }\end{array}$ & $\begin{array}{l}\text { New pre- } \\
\text { Contact } \\
\text { sites } \\
\text { recorded } \\
\end{array}$ & $\begin{array}{l}\text { New } \\
\text { historical } \\
\text { sites } \\
\text { recorded } \\
\end{array}$ & $\begin{array}{l}\text { \# sites } \\
\text { within } \\
\text { o.5mile } \\
\end{array}$ & $\begin{array}{l}\text { \# sites } \\
\text { within } 0.5- \\
\text { 1.5mile }\end{array}$ \\
\hline All & 78 & 54 & 25 & 5.4 & 2.5 & 14 & 3 & $\begin{array}{l}\text { mean }=5.8 \\
\text { st.dev.3.84 }\end{array}$ & $\begin{array}{l}\text { mean }=2 \\
\text { st.dev. } 2.2\end{array}$ \\
\hline $\begin{array}{l}\text { Sheep } \\
\text { Range }\end{array}$ & 36 & 25 & 12 & 4.17 & 2 & 7 & 1 & $\begin{array}{l}\text { mean=3.17 } \\
\text { st.dev.1.22 }\end{array}$ & $\begin{array}{l}\text { mean=2.83 } \\
\text { st.dev.3.11 }\end{array}$ \\
\hline $\begin{array}{l}\text { Las Vegas } \\
\text { Range }\end{array}$ & 42 & 29 & 13 & 7.25 & 3.25 & 7 & 2 & $\begin{array}{l}\text { mean }=9.7 \\
\text { st. dev.7.63 }\end{array}$ & $\begin{array}{l}\text { mean=.75 } \\
\text { st.dev.0.75 }\end{array}$ \\
\hline Spring 1 & 14 & 13 & 1 & - & - & 1 & $\mathrm{O}$ & 3 & 11 \\
\hline Spring 2 & 5 & 3 & 3 & - & - & 1 & 1 & 5 & $\mathrm{O}$ \\
\hline Spring 3 & 4 & 3 & 2 & - & - & 2 & 0 & 2 & 2 \\
\hline Spring 4 & 2 & 1 & 1 & - & - & 1 & $\mathrm{O}$ & 2 & $\mathrm{O}$ \\
\hline Spring 5 & 6 & 3 & 2 & - & - & 0 & 0 & 2 & 4 \\
\hline Spring 6 & 5 & 2 & 3 & - & - & 2 & $\mathrm{O}$ & 5 & $\mathrm{O}$ \\
\hline Spring 7 & 4 & $\mathrm{O}$ & 4 & - & - & 0 & 2 & 4 & $\mathrm{O}$ \\
\hline Spring 8 & 5 & 3 & 2 & - & - & 3 & 0 & 5 & O \\
\hline Spring 9* & $26 *$ & $22^{*}$ & $4^{*}$ & - & - & $2^{*}$ & $\mathrm{O}^{*}$ & $25^{*}$ & $1^{*}$ \\
\hline Spring 10 & 7 & 4 & 3 & - & - & 2 & $\mathrm{O}$ & 5 & 2 \\
\hline
\end{tabular}

*Due to inconsistencies in existing records found in the NVCRIS database, these numbers represent minimums for Spring 9; total records of archeological sites and isolates within 1.5 miles of Spring 9 may number up to 49. 
Table 9. Presence/absence of types of pre-Contact artifact and features at each spring (' $X$ ' designates one or more records).

\begin{tabular}{|c|c|c|c|c|c|c|c|c|c|c|c|c|c|}
\hline \multirow{2}{*}{$\begin{array}{l}\text { Pre-Contact } \\
\text { artifact type }\end{array}$} & \multirow{2}{*}{\begin{tabular}{|l|} 
All \\
springs \\
in \\
study
\end{tabular}} & \multirow{2}{*}{$\begin{array}{l}\text { Sheep } \\
\text { Range }\end{array}$} & \multirow{2}{*}{$\begin{array}{l}\text { Las } \\
\text { Vegas } \\
\text { Range }\end{array}$} & \multicolumn{10}{|c|}{ Spring } \\
\hline & & & & & 2 & 3 & 4 & 5 & 6 & 7 & 8 & 9 & 10 \\
\hline \begin{tabular}{|l|} 
Total \\
number of \\
artifacts \\
represented \\
\end{tabular} & 7 & 8 & 6 & 1 & 4 & 3 & 1 & 5 & 2 & 0 & 3 & 4 & 3 \\
\hline $\begin{array}{l}\text { Lithic } \\
\text { scatters }\end{array}$ & & 3 & 4 & - & $\mathrm{X}$ & $\mathrm{X}$ & - & $\mathrm{X}$ & - & - & $X$ & $\mathrm{X}$ & $X$ \\
\hline $\begin{array}{l}\text { Roasting } \\
\text { pits }\end{array}$ & & 6 & 3 & $\mathrm{X}$ & $\mathrm{X}$ & X & X & $\mathrm{X}$ & X & - & X & X & $X$ \\
\hline $\begin{array}{l}\text { Petroglyph/ } \\
\text { pictographs }\end{array}$ & & 2 & 0 & - & $\mathrm{X}$ & - & - & X & - & & - & - & - \\
\hline $\begin{array}{l}\text { Dugouts/ } \\
\text { Rock } \\
\text { shelters }\end{array}$ & & 2 & 2 & - & $\mathrm{X}$ & - & - & - & $\mathrm{X}$ & - & - & $\mathrm{X}$ & $\mathrm{X}$ \\
\hline \begin{tabular}{|l|} 
Groundstone \\
scatter
\end{tabular} & & 1 & 1 & - & - & - & - & $\mathrm{X}$ & - & - & - & $\mathrm{X}$ & - \\
\hline Ceramics & & 1 & 0 & - & - & - & - & $\mathrm{X}$ & - & - & - & - & - \\
\hline \begin{tabular}{|l} 
Other (rock \\
formation, \\
hunting \\
blind, \\
heating \\
element) \\
\end{tabular} & & 0 & 1 & - & - & $\mathrm{X}$ & - & - & - & - & $\mathrm{X}$ & - & - \\
\hline
\end{tabular}


Roasting pits-- the most represented type of feature-- point to gathering and processing of food resources-- most notably agave and pine nuts. Nuwu/Nuwuvi camped near springs, which provided drinking water while they processed seasonal foods. According to Lodge (2016), there are over 200 roasting pits in the Sheep Range. The abundance of roasting pits throughout the Sheep Range may be related to the intensification of land use and resources by Indigenous peoples between 2,000 and 4,000 years ago (Lodge 2016). Lithics are also commonly found near springs. Lithic scatters represent tool processing activities, and projectile points indicate people hunted sheep, deer, and other mammals dependent on the springs. According to the interview with the Desert NWR Archaeologist, rock-shelters provided protection from the elements and likely had spiritual/religious use (2016b). Pictographs and petroglyphs thought to have spiritual connotations may be associated with nearby springs considered places of power (Spoon et al. 2012b), and/or indicated directions to water (Spoon et al. 2011). Ceramic ware and surface hearths (different from roasting pits) are the least-commonly documented pre-Contact artifact type, noted at only Spring 5 and Spring 8, respectively. The abundant pre-Contact artifacts and features provide physical evidence of their centrality to Indigenous lifeways and indicate a range of activities occurred around them.

Archaeology provides one line of evidence to elucidate the roles of natural and anthropogenic disturbance in spring ecosystems (Kodrick-Brown and Brown 2007). Indigenous use of springs stretches back over 11,000 years in North America, and far longer in Europe, Africa, Asia, and Australia (Haynes 2008). 
Consequently, springs also emerge as important paleontological and archeological sites for understanding landform, human, and cultural evolution (Sinclair et al. 2018). Pathways for further research could explore what paleoecological data, including analyses of sediments, roasting pits, and packrat middens, could be gleaned to learn more about this early period in the humanspring history (Stevens and Meretsky 2008). Any alterations made to springs in pre-Contact times are no longer overtly visible, although above-ground archaeological survey amply supports the living memory of seasonal use by Nuwu/Nuwuvi when moving between upland and lowland resource areas across the territory. With the full consent of tribal representatives, testing for pollen, charcoal, and below ground archaeology may reveal more nuanced information such as historical vegetation assemblages and how Nuwu/Nuwuvi managed and impacted spring ecology.

Nuwu/Nuwuvi Traditional Ecological Knowledge and Management of Springs

Nuwuvi hydrological knowledge and relationship to springs developed over millennia and represents an integral part of the Sheep and Las Vegas Mountain historical ecology. The Creator charged Nuwu/Nuwuvi with a responsibility for living in balance with the land through respectful partnership with all elements of the earth (Spoon et al. 2013). Nuwu/Nuwuvi view water as a sentient entity that requires human interaction in order to remain healthy. Many springs are places of healing, ceremony, and the home of spiritual beings (Spoon 
et al. 2012c). According to Wendel (2012), Nuwu/Nuwuvi indicators of spring health include consistent, freely flowing water, the presence of riparian vegetation, and regular use by wildlife. As part of their stewardship practices, $\mathrm{Nuwu/Nuwuvi} \mathrm{manage} \mathrm{the} \mathrm{vegetation} \mathrm{growth} \mathrm{around} \mathrm{springs} \mathrm{to} \mathrm{improve} \mathrm{access}$ not only for themselves but for the many animals that also depend on and "watch over" springs (Spoon et al. 2012c; Spoon et al. 2013:63). Nuwu/Nuwuvi traditionally maintain spring health by clearing debris from springs and paying respect through songs, prayers, and the observance of taboos. Certain springs and water places feature in Nuwu/Nuwuvi ceremonial Salt Songs, which guide one on a spiritual journey along ancestral trails through the territory and describe sacred places along the way (Spoon et al. 2013). Water spirits inhabit springs and require respectful interaction. This includes taboos against loud noises and disturbing the water. Nuwu/Nuwuvi believe that when the water is disturbed, it speaks to other resources both above and below ground, upstream and downstream-as they consider all the water connected and integral to the health of the land. Disturbing or neglecting a spring can cause the water to temporarily retreat underground or permanently disappear. Therefore, it is vital to recognize these connections and not cause any disturbance to the water sources in the mountain or other areas (Wendel 2012; Spoon et al. 2013).

A Pahrump Paiute elder illustrates the cultural salience of these sources of water for desert dwellers, stating: "it was so important that each spring-- even the smallest one, down to the minute ones-- had a name" (Spoon et al. 2012c). Of the 230 place names recorded by anthropologist Isabel Kelly (1933) in the Las Vegas- 
Pahrump Nuwu/Nuwuvi tribal territory, I counted that 93 were names of springs, comprising the most represented place-type. The naming of all springs speaks to the intimate relationship people had with them, where springs also "know you". The names remembered and recorded provide descriptive historical information about spring morphology, setting, and vegetation throughout the territory, with translations such as: Purple Willow Small Water; Sand Boils Water; Summit Water; and Willows Standing in a Line Water, which designates a spring brook (Fowler 2002; Sapir 1931). The ethnographies I consulted contained the Nuwu/Nuwuvi names (but not translated meaning) of two of the ten springs in my study: Spring 9 and Spring 10, both of which are located within prominent pine nut gathering areas.

To summarize, Nuwu/Nuwuvi relationships with springs are based upon a social construction of nature that springs, and all parts of the natural world, are sentient and related. As part of this kincentric worldview (Salmon 2001; Kimmerer 2014), Nuwu/Nuwuvi are part of an extended ecological family that shares ancestry and origins, where all the natural elements of an ecosystem are respected and their mutual roles recognized as essential for their health or balance, and survival. Due to this non-dual conception of humans and nature, the concept of human ownership over land and its resources is foreign (Spoon et al. 2013). Rather, families traditionally used and cared for certain springs and territories that they belonged to, and granted this permission to other groups at territorial boundaries and during times of need. Nuwu/Nuwuvi subsistence lifeways in the pre-Contact Era extended from this ethic of care and respect by 
only taking what they needed for subsistence, leaving enough for other species and keeping the land in balance. As a result of improper spirituality and improper behavior with the earth, spring spirits could become angered and spring water would disappear underground.

Nuwuvi knowledge of springs echoes cross-cultural Indigenous views that water is sacred. Nuwu/Nuwuvi use spring water in ceremony as a purifier and source of power, as well as for plant and spiritual medicine (Spoon et al. 2012c). Loftin (1991) describes that to the Hopi of northeast Arizona, water is the essence of the sacred, and that shortages are the consequence of improper spirituality, which shows up in ignorant or greedy interactions with the earth mother. In an ethnographic study of First Nations' perspective on water, Blackstock (2001) elders describe that water is the primary substance within the interconnected web of life; it is the center of the web, rather than being just one component. Nuwu/Nuwuvi, along with numerous Indigenous knowledge traditions, understand that all waters are interconnected and springs are considered to be portals or axes through which great spiritual power travels to the rest of the landscape and other worlds (Spoon et. al 2013; Stoffle 2002; Chief et al. 2016; Eliade 1958). The Western scientific concept of the Water Cycle does, at its core, also proffer that all water is interconnected, as groundwater circulates endlessly through phases of precipitation as rain or snow, infiltration into aquifers, upwelling, and evaporation/transpiration. However, in comparison to Nuwu/Nuwuvi knowledge, settler attitudes and policies driven by market 
capitalism exhibit a compartmentalized, utilitarian, and inanimate view of water (Johntson 2003).

Based upon an assemblage of data sourced from contemporary and $20^{\text {th }}$ century ethnographies, archaeological survey, and the literature, I argue that Nuwu/Nuwuvi embodied a kin-centric, mutualistic relationship to springs; this supported an ethic of moderated use and small-scale disturbance through practices spanning physical and spiritual care, and may have fostered diverse and resilient spring systems. In the next section, I outline the changes that occured to and around spring systems following Euro-American settlement in the Las Vegas Valley around 1850. 


\subsection{Euro-American Settler Era, 1850-1936}

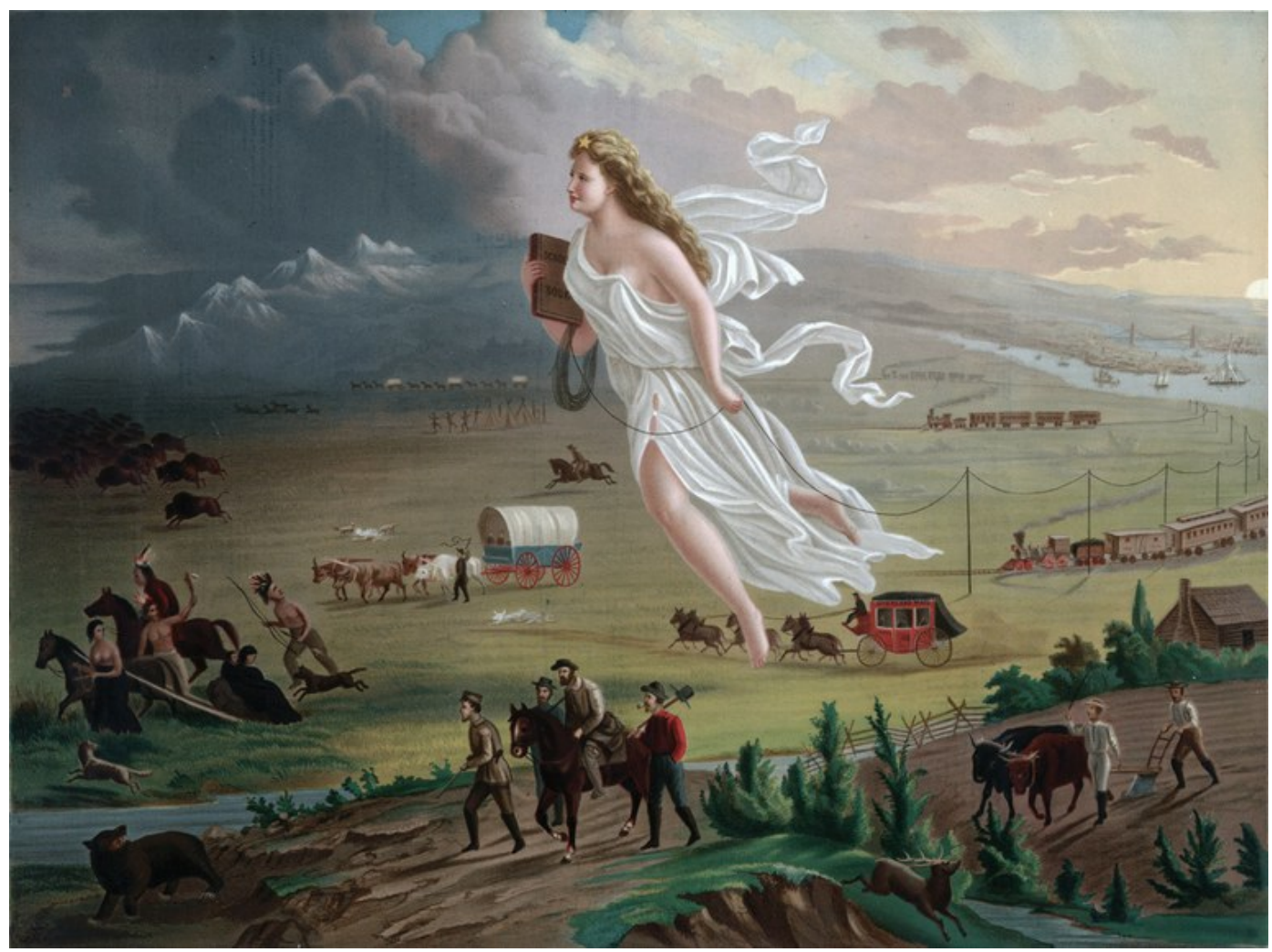

Image 4. American Progress, John Gast, 1872.

In the following section, I argue that settler-colonial concepts of humans as separate from nature and a utilitarian value of springs led to the systematic development of springs via both informal/rudimentary means and legally mandated water policy. These practices created lasting, extant changes and degradation to the ecological form and functioning of these groundwater dependent ecosystems. I argue that coinciding global, anthropogenic climate changes likely magnified the impact of regional social-environmental disruption 
and local manipulation of springs following Euro-American settlement (Morris \& Rowe 2014; Miller and Wigand 1994; Koch et al. 2019).

\section{Euro-American Settler Era Background}

Spanish missionaries were among the first colonials to travel through Nuwu/Nuwuvi territory in 1776 via the Old Spanish Trail from New Mexico to the San Bernardino mission in California. The valley between the Spring Mountains and Sheep Mountains was then green with spring-fed mesquite groves and grasslands, earning the name Las Vegas for its meadows. Eurasian diseases and slave raids preceded colonial arrival and severely impacted Nuwu/Nuwuvi social structure even prior to direct contact with Europeans (Roberts et al. 2007). In 1848, the present day Refuge lands were among those ceded to the US after the Mexican-American War. Coinciding with the California Gold Rush, an influx of mining prospectors and Mormon missionaries arrived via Mormon Well Road to prospect and settle the Las Vegas Valley. The immigrants seized control of Nuwu/Nuwuvi water sources, gathering sites, and hunting grounds, launching sporadic attacks to force Nuwu/Nuwuvi from their spring encampments and gardens. The brief presence of Mormon missions in Las Vegas and Moapa in 1854-1867 sought to reorganize not only their worldview but also to divide and conquer intractable social and political bonds among Nuwu/Nuwuvi groups across their territory. The violence and pressure upon Nuwu/Nuwuvi resources brought retaliation, followed by military intervention and the forced relocation of Indigenous communities to reservations (Deur and Confer 2012). While 
Nuwu/Nuwuvi remained in the landscape, settler colonial occupation displaced them from the springs and resource sites that were the cornerstone of their culture and lifeways (Roberts et al. 2007; Fowler 2012). I argue that this displacement and transformation of human interactions with springs entailed profound changes to spring use, management, and ecological condition via ideological, political-economic (legislative), and climatic forces. This justifies differentiation from the primarily-Indigenous, pre-contact regime to the Settlerdominant historical ecological Era, even though the shift in regime did not entirely pre-clude Nuwu/Nuwuvi use and influence of springs.

\section{Manifest Destiny}

Manifest Destiny played a central role in Euro-American conquests and Westward expansion into Nuwu/Nuwuvi homelands. This ideology alleged that the continent was fated by God to be conquered, tamed, Christianized, and capitalized upon by the newly independent American nation. US leaders articulated this political strategy to justify tenuous territorial expansions during a period of significant population growth and conflict with Mexican and European powers in North America (Stephanson 1996). This expression of the expansionist, settler-colonial religious- political-economic system arises from the ontological duality that Euro-American are separate from and superior to nature (Ingerson 1994). Used to place humans in a role of power-over a knowable and measurable nature, "natural resources" are compartmentalized, controlled, and 
exploited for material gain. Used to legitimize the takeover and transformation of Nuwu/Nuwuvi lands, these were also part of the policy programs intended to re-

shape Indigenous peoples into manageable and productive subjects. The nexus of settler ideologies of "civilization and "improvement" and the deployment of water law has been at the core of settler colonialism and continues in postcolonial forms (Boelens et al. 2006).

\section{Water Rights Doctrine of Prior Appropriation}

Led by the myth of Manifest Destiny, a Christian ideology of dominion over nature, and a drive for economic expansion, legislation encouraged and regulated the "improvement" of land with irrigation and other "productive" uses of water through homesteading acts and water rights policy. The state-based water rights doctrine of Prior Appropriation enacted in 1908 played a highly influential role in the postcolonial historical ecology of the springs landscape. Known as "first in time, first in right", water belongs to the first user who appropriates it for beneficial use, and senior water rights are guaranteed even as new uses for water are allocated. Adopted throughout the Western states, the law evolved to promote mining, settlement, and development in the West by diverting water from an above ground or below ground source and applying it to (sometimes distant) land. This entailed the physical control of water through measurable diversion from a source, and its full application to a socially deemed "beneficial" use according to the policy. In addition to domestic use for their 
homesteads, missions, and farms, settlers then (and now) intensified spring exploitation for activities that generate economic benefit, such as livestock watering, mining prospects, agricultural irrigation, "without waste". With the shortsighted goal of diverting all available water for measurable consumption, users must continually demonstrate the full utilization of allocated water or else forfeit the rights (Cech 2005; USFS et al. 1998).

The water rights law appears as a focal point in descriptions of arid spring ecosystems during the early $20^{\text {th }}$ century (USFWS Archives) and influenced the perception and relationships to springs by encouraging settler communities to develop and extract from seemingly limitless aquifers in a free-for-all manner (Pavelko et al. 1991). Developed in ignorance of the more-than-economic value of spring systems, State and Federal water rights laws continue to uphold the yardstick of "productive" management approaches to groundwater over nonmaterial, cultural, or intrinsic purposes (Welden 2003). This doctrine is a cornerstone of human-environmental dynamics in the Western U.S. (and, some would argue, it's headstone too). It upholds diversionary, utilitarian, consumptive uses of springs-a paradigm that is conceptually at odds with Nuwu/Nuwuvi beliefs and customs, whose tradition states that springs are sentient and requiring human interaction to remain healthy (Bryan 2017; Spoon et al. 2012c). State-sanctioned appropriation of water overruled generations of Nuwu/Nuwuvi -spring relationships and nullified the existing indigenous kinship-based systems of spring occupation by family groups (Fowler 2012; Spoon et al. 2012). This left starvation and destitution in its wake, forcing Nuwu/Nuwuvi to the fringes of 
their territories and many to work for settler ranches. Although the Tribal Reserved Rights Doctrine (or Winters Doctrine) set aside federally reserved water rights for Native American reservations (Bryan 2017), the Las Vegas Paiute Reservation (est. 1986) received only a fraction of their claim to adjudicated water rights through federal court (Kropf 1999).

In contrast to the Riparian Doctrine of water rights largely applied in the Eastern states, Prior Appropriation separates water rights from land holding, meaning that distant claims to water-both spatially and far back in time-can effectively dry up "downstream” supply. This policy has proven flawed for its inability to account for temporally and spatially variable exchange fluxes between groundwater and surface waters, which have significant impact on the water balance and recharge to basins (Welden 2003). As the city of Las Vegas developed and expanded, many springs fed by the Las Vegas Valley aquifer that underlies the Refuge dried up (Pavelko et al. 1991; Hulse 2009). Most watersheds in Nevada and the Refuge rapidly became appropriated at or above an estimated, fixed maximum perennial yield-meaning above and below ground water systems are over-drafted on a yearly basis. This practice is common throughout the West, with the over-allotment of the Colorado River (which no longer reaches Mexico) serving as one of the more visible examples. I expound upon groundwater extraction and possible threat to the Refuge springs in the Discussion chapter.

Settlement and Ranching around Springs 
While their difficulty of access and relatively small yields made most Refuge springs unsuitable for extensive domestic or agricultural use, they were broadly developed for livestock and cattle grazing. Between 1885 and 1936, private rights holders appropriated and developed eight of the 10 springs in this study (and 16 out of 34 on the Refuge), leaving only the most inaccessible springs and seeps untapped. USFWS archival records of water rights documentation, photographs, and in-situ archaeological evidence help reconstruct settlers' intentions and processes of improving springs for livestock watering. Spring 6 and Spring 5 were also utilized for "domestic use", as bases for hunting and trapping, and for bootlegging of liquor during Prohibition, as indicated by the remains of alcohol stills found during previous archaeological surveys (NVCRIS n.d). Mining test holes located near two springs are evidence of mineral prospecting activities, though I found no evidence to indicate the spring sources were used directly in mining on the Refuge (see Appendix G for priority appropriation of water rights for the ten springs included in this survey presented in chronological order).

I summarize archaeological evidence of historical activity (i.e. estimated to be more than fifty years old) near springs based on research within the NVCRIS database (NV SHPO 2017), USFWS files, and ten pedestrian surveys conducted in October 2016 (Table 8; Table 10). These included two historical sites nominated to the NRHP: the juniper post corral at Spring 9 and the cabin at Spring 6. I expound upon archaeological evidence for Settler Era activity in Table 11. Each spring featured physical or documented evidence of historical developments for 
livestock and/or later, wildlife. I generally recorded fewer occurrences of historic archaeology than pre-Contact archaeology. The median historical sites/evidence recorded at each spring numbered two, versus three for pre-Contact sites.

Image 5. Cabin built in 189os near Spring 6, 1975 (USFWS Archives).

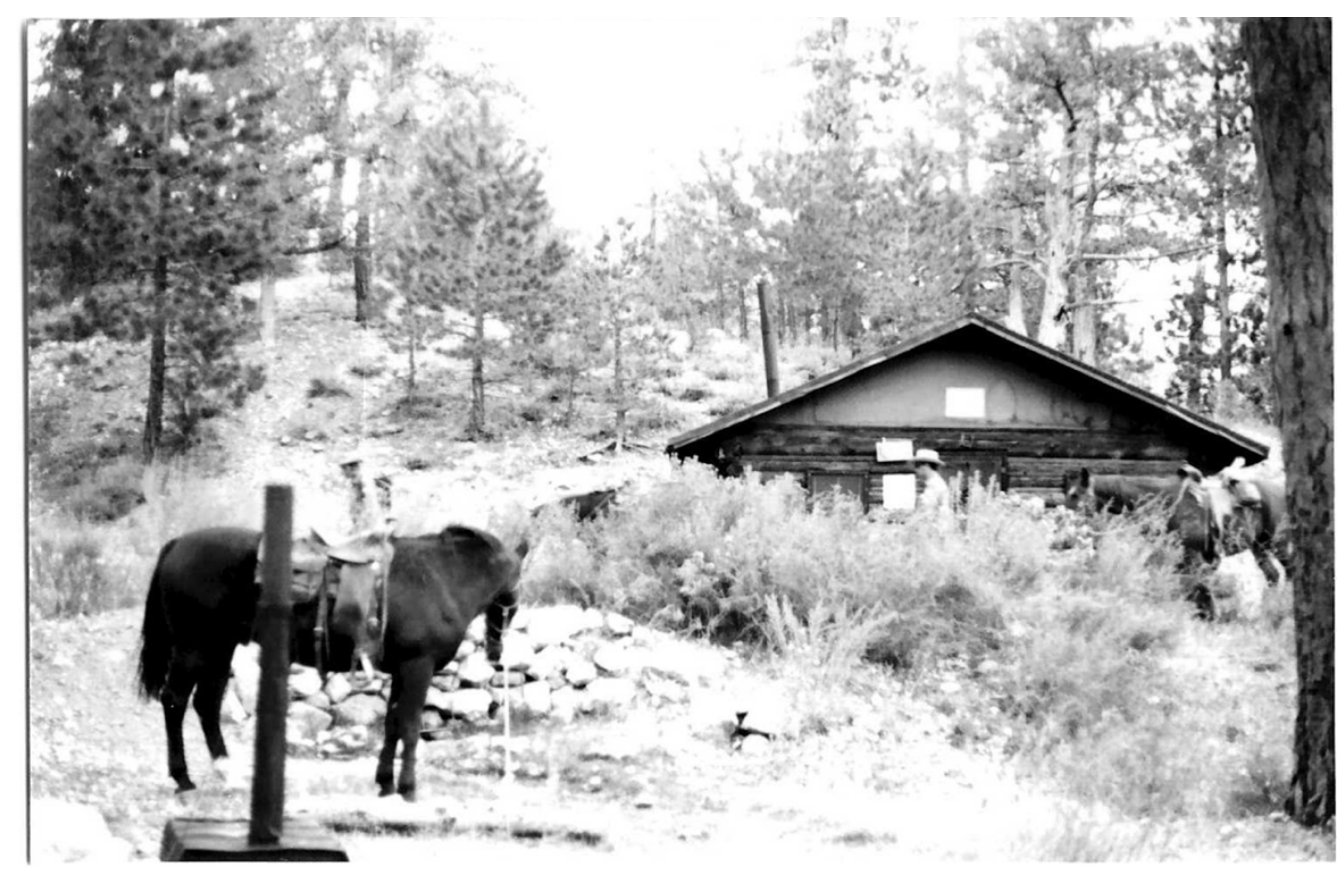


Table 1O. Presence/Absence of historical artifact types recorded at each spring ( $X$ designates one or more records)

\begin{tabular}{|c|c|c|c|c|c|c|c|c|c|c|c|c|c|}
\hline $\begin{array}{l}\text { Historic artifact } \\
\text { type }\end{array}$ & \begin{tabular}{|l} 
All \\
springs \\
in \\
study
\end{tabular} & $\begin{array}{l}\text { Sheep } \\
\text { Range } \\
\text { springs }\end{array}$ & \begin{tabular}{|l} 
Las \\
Vegas \\
Range \\
springs
\end{tabular} & $\begin{array}{l}\text { Spring } \\
1\end{array}$ & \begin{tabular}{|l|} 
Spring \\
2
\end{tabular} & \begin{tabular}{|l|} 
Spring \\
3
\end{tabular} & \begin{tabular}{|l|} 
Spring \\
4
\end{tabular} & \begin{tabular}{|l} 
Spring \\
5
\end{tabular} & $\begin{array}{l}\text { Spring } \\
6\end{array}$ & $\begin{array}{l}\text { Spring } \\
7\end{array}$ & $\begin{array}{l}\text { Spring } \\
8\end{array}$ & \begin{tabular}{|l|} 
Spring \\
9
\end{tabular} & $\begin{array}{l}\text { Spring } \\
10\end{array}$ \\
\hline $\begin{array}{l}\text { Total } \\
\text { number of artifacts } \\
\text { represented }\end{array}$ & 8 & 7 & 6 & 2 & 5 & 2 & 2 & 5 & 4 & 3 & 2 & 4 & 4 \\
\hline Cabin & & 2 & 0 & - & - & - & - & $\mathrm{X}$ & $\mathrm{X}$ & - & - & - & - \\
\hline Corral/fencing & & 3 & 2 & - & $\mathrm{X}$ & - & - & $\mathrm{X}$ & $\mathrm{X}$ & $\mathrm{X}$ & - & $\mathrm{X}$ & - \\
\hline $\begin{array}{l}\text { Refuse } \\
\text { scatter (e.g. food } \\
\text { cans, tobacco tins, } \\
\text { glass bottles, } \\
\text { vehicle remnants) }\end{array}$ & & 6 & 4 & $\mathrm{X}$ & $\mathrm{X}$ & - & $\mathrm{X}$ & $\mathrm{X}$ & $\mathrm{X}$ & - & - & $\mathrm{X}$ & $\mathrm{X}$ \\
\hline Ceramic ware & & 1 & 1 & - & - & - & - & - & - & - & - & - & $\mathrm{X}$ \\
\hline \begin{tabular}{|l|} 
Pictographs \\
/Petroglyphs
\end{tabular} & & 2 & 0 & - & $\mathrm{X}$ & - & - & - & - & - & - & - & - \\
\hline \begin{tabular}{|l} 
Water \\
developments
\end{tabular} & & 6 & 4 & $\mathrm{X}$ & $\mathrm{X}$ & $\mathrm{X}$ & $\mathrm{X}$ & $\mathrm{X}$ & $\mathrm{X}$ & $\mathrm{X}$ & $\mathrm{X}$ & $\mathrm{X}$ & $\mathrm{X}$ \\
\hline $\begin{array}{l}\text { Mining pits/bore } \\
\text { holes }\end{array}$ & & \begin{tabular}{|l}
1 \\
\end{tabular} & 2 & - & - & - & - & $\mathrm{X}$ & - & - & $\mathrm{X}$ & - & $\mathrm{X}$ \\
\hline $\begin{array}{l}\text { Other (rock } \\
\text { formation, hunting } \\
\text { blind, heating } \\
\text { element) } \\
\end{array}$ & & & 1 & - & $\mathrm{X}$ & $\mathrm{X}$ & - & - & - & $\mathrm{X}$ & & $\mathrm{X}$ & - \\
\hline
\end{tabular}


Table 11. Settler activities near springs and associated archaeological sites

\begin{tabular}{|c|c|c|}
\hline Settler Activity & Artifact/ Features & Location \\
\hline \multirow[t]{2}{*}{ Ranching/Grazing } & Corral; fencing & Spring 6, Spring 7, Spring 5, Spring 9 \\
\hline & $\begin{array}{l}\text { Spring developments } \\
\text { (eg. Piping, cast iron bathtubs, } \\
\text { drinking troughs, storage tanks, } \\
\text { springbox, fencing, shovels) }\end{array}$ & All Springs \\
\hline \multirow[t]{6}{*}{$\begin{array}{l}\text { Domestic; } \\
\text { Hunting, Recreation, } \\
\text { and Bootlegging }\end{array}$} & Cabin & $\begin{array}{l}\text { Spring 6; Spring } 5 \\
\text { The cabin which still stands at Spring } \\
6 \text { is the other historic site nominated } \\
\text { to the NRHP. Built by settlers } \\
\text { between } 1880-1920 \text {, it served as a } \\
\text { base for hunting and trapping } \\
\text { activities prior to the Refuge } \\
\text { establishment. During the } \\
\text { Prohibition Era, the cabin was also } \\
\text { the site of bootlegging activity, as was } \\
\text { the makeshift cabin at Spring } 5 \text {, } \\
\text { where archaeological surveys noted } \\
\text { remnants of a still (USFWS archives; } \\
\text { NVCRIS). The cabins were later used } \\
\text { by USFWS game wardens for } \\
\text { trapping and other wildlife habitat } \\
\text { management activities according to } \\
\text { early USFWS accounts (USFWS } \\
\text { 1939). Today, the cabin is used for } \\
\text { overnight shelter by hikers who enjoy } \\
\text { the drinking water from the spring. }\end{array}$ \\
\hline & $\begin{array}{l}\text { Refuse scatter e.g. food cans, } \\
\text { tobacco tins, glass bottles, vehicle } \\
\text { remnants }\end{array}$ & All springs \\
\hline & Ceramic & Spring 10, Spring 2 \\
\hline & Spring developments & All Springs \\
\hline & Euro-American Pictographs & Spring 2 \\
\hline & Euro-American hunting blinds & Spring 2, Spring 3, Spring 10 \\
\hline Mining/Prospecting & Prospecting pit, bore holes & Spring 5; Spring 8 \\
\hline
\end{tabular}




\section{Settler Management of Springs}

Euro-American settlers defined the value or health of a spring by its utilitarian and economic potential. Notes made in archival records use the descriptor "good water" to denote a spring with abundant, year-long flow, which provided reliable water for use by cattle and livestock, domestic use, and drinking water when traveling through the area. Further, the higher water table found around some springs was favorable to supporting good forage for cattle.

Spring improvements for livestock affected the ecology of springs due to the diversion of water, trampling of the spring source, overgrazing, and spread of invasive species (Fleischman et al. 2006; Abele 2011), all of which posed a threat to spring biota. By placing a spring box over the water source and piping most or all of the water off the site into livestock tanks, the flow and structure of the spring was lost, and often no exposed water remained on the surface (Fleischman et al. 2006; Sada and Vineyard 2002; Brussard et al. 2015). Although some of the riparian vegetation may be retained with such practices, the reduction of riparian areas in Great Basin springs is shown to have entailed the loss of invertebrates and endemic species, such as springsnails (e.g. Pyrgulopsis spp.)(Patten et al. 2008). The trampling and overgrazing of surrounding shrub and herbaceous cover further impacts spring ecosystems, for instance affecting nutrient cycling and water temperature (Sada et al. 2005), also modifying many bird and small mammal communities (Sada and Vineyard 2002). A structurally diverse flora in riparian communities that has not been grazed supports a broad assemblage of wildlife species. Lastly, it is possible that the on-site excavations and construction 
works to develop springs may have disturbed archaeological materials (see Image 6 below), as described in surveys of Spring 5 (USFWS Archives).

Image 6. Older trough and bathtub contain Spring 5. Historically used by livestock, hunters, and bootleggers, agave is abundant in this area and archaeologists noted the tubs may have been placed within the remains of a pre-Contact roasting pit.

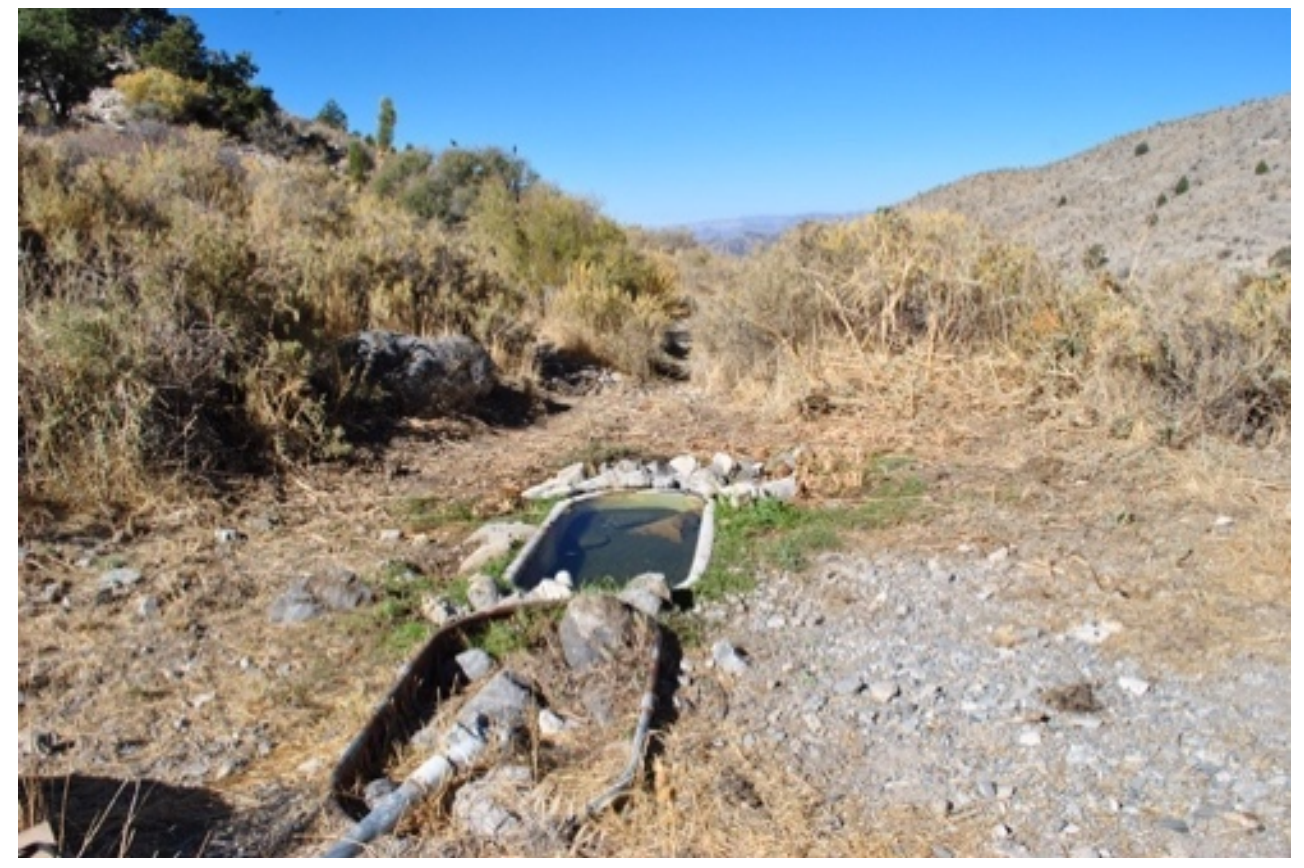

Case Study: Spring 9

To illustrate examples of settler-spring ecology, I focus on Spring 9. Historically, it is the most intensively utilized of the upland springs on the Refuge among Nuwu/Nuwuvi, settler, and federal land managers alike thanks to its combination of abundant water, accessibility, and favorable setting for pine nuts, grazing, and bighorn sheep at the foothills of the Las Vegas Range. It was 
nominated to the National Register of Historic Places for its pre-Contact archaeological sites and long history of Indigenous use as a preferred pine nut harvesting camp (Nevada SHPO, n.d.). I recorded two lithic sites in the area of Spring 9 possibly related to campsites recorded in previous surveys.

Mormon immigrants to the Las Vegas Valley stopped at this spring along the well-traveled Mormon Well Road (Knack 2001), and likely manipulated them decades before the existence of water rights appropriation records. The USFWS spring archives show that in 1896, four ranchers initially appropriated Spring 9 along with Spring 10. A pair of ranchers acquired the rights to both springs in 1909 and grazed cattle here until the 1960s, perhaps moving livestock between them to fresh forage across what was then federal Bureau of Land Management lands. The juniper post corral at Spring 9 dates from the late 1890 . It stands as a testament to the hundreds of cattle once pastured there and the substantial spring flows that supported their numbers for over six decades (USFWS archives). Remnants of multiple troughs suggest there may have at one time been multiple seeps. USFWS narrative reports from 1945 and 1956 note that the abundant grass around the Spring 9 made the spring an attractive and contested location for grazing. In the first decades of Refuge establishment, the USFWS had not yet acquired the water rights to this spring from the private ranchers. The Refuge manager who wrote the Annual Narrative Report bemoaned that the source could be developed to good advantage for wildlife if it were Service owned, but that "any improvement at this point, however, might encourage bringing more livestock into the locality which would be detrimental to the game 
management program" (USFWS archives, 1956). This highlights the complexity and conflict surrounding springs during this time of concurrent land uses for wildlife conservation and cattle grazing in the early decades of the Refuge. Indeed, annual narrative reports between 1938 and 1968 also indicate overgrazing in the area of Spring 9 springs, an indirect ecological impact of spring development (USFWS archives). During botanical surveys, I recorded an abundance of cheatgrass (Bromus tectorum) and red brome (Bromus rubens), two invasive introduced graminoids that became widely established as a result of grazing on the Refuge during the Settler era (Interview with Refuge Manager, 2016). The history of development and negative impacts on spring structure and surrounding vegetation at Spring 9 encompasses many similar findings across the other springs in my study. It also echoes other research from the Great Basin (e.g. Brussard et al. 2015) that demonstrates the effect of livestock on riparian habitats is often so severe that those habitats no longer represent native vegetation, and faunal communities are reduced to widespread, ecological generalists that are adapted to such highly disturbed conditions.

\section{Anthropogenic Climate Change Magnified Settler Disturbance}

Zooming out to the changing climatic conditions provides insight into the underlying context and resulting consequences of colonization and settlement for the springs. Using recent climate analysis (Koch et al. 2019), I argue that colonization impacted springs more than 200 years prior to the physical arrival of 
settlers. Considering the strong link between rates of spring discharge and precipitation pattern, I argue that coinciding climate change only magnified the social, cultural and ecological disruption of Nuwu/Nuwuvi-spring relationships following Euro-American settlement in the age of Manifest Destiny.

The Little Ice Age (1300-1850), an anomalously cool and wet period worldwide and in the Southern Great Basin, occurred during the current interglacial warming trend of the interglacial Holocene Epoch (11,700 BPpresent). It is notable as the earliest climate variation to be precipitated by human causes: the colonization of the Americas. Little Ice Age (1300-1850). European contact claimed the lives of 55 million Indigenous peoples between 1492 and 1600, through disease, conquest, and social collapse. Called the Great Dying, this large-scale depopulation caused the abandonment and secondary succession (reforestation) of 56 million hectares (135 million acres, roughly the size of France) of formerly tended land across the Americas. Recent research from Koch et al. (2019) linked this land use change to the rapid reuptake of 3.5 ppm of atmospheric $\mathrm{CO} 2$ and decrease in average temperatures globally by 1-3 Fahrenheit. Based upon Miller and Wigand's (1994) climatologic analyses of spring mounds and pollen in packrat middens in Southern Nevada, I found that this period corresponds to higher rates of precipitation and increased volumes of springtime snowmelt in Nuwu/Nuwuvi homelands and indicates that local and regional springs systems had relatively higher of recharge and increased surface flow for nearly 500 years. 
Around 1850, the climate resumed the broader warming and drying trend that continues today (MacDonald 2010), and spring water became only more critical and limited to local inhabitants. Colonial violence interrupted many of the ancient adaptations between springs and Nuwu/Nuwuvi, disconnecting ancestral systems of hydrological knowledge and spring tending, along with the ecological balance of spring ecosystems. I suggest that these impacts of colonization were only magnified by coinciding drought. Ecologically speaking, the decreased precipitation and higher temperatures following the Little Ice Age may have aggravated settler impacts on spring ecology by slowing vegetation regrowth after spring development or facilitating the establishment of generalist invasive species (Sada 2002, Seager et al. 2007; Brussard et al. 2015). Through their resilience, springs nonetheless remain an epicenter of Nuwu/Nuwuvi knowledge and spiritual and ecological balance (Spoon et al. 2013). How Nuwu/Nuwuvi made meaning of the climatic shift that coincided with Euro-American settlement should be explored in further research.

In conclusion, Euro-American settlement impacted springs not only through the regional social-environmental disruption and local manipulation of springs, but also indirectly via global climate changes impacting the springs landscape (Morris \& Rowe 2014; Miller and Wigand 1994; Koch et al. 2019). Zooming out to the global scale reminds us that human land management practices had global impacts on the Earth system centuries prior to the Industrial Revolution. This places $1610 \mathrm{CE}$ as the start of the Anthropocene (Koch et al. 2019), the current geological age which defines human activity as a major driver 
of climate and environmental change (Lewis \& Maslin 2015; Waters et al. 2016). Although abstract, it is a notable turning point in the springs' historical ecology. A historical ecology lens reveals that as springs continue to be affected by global anthropogenic climate change and settler-led management regimes on Indigenous lands, it is necessary to address the large scale origins of local environmental issues. At the same time, adaptive solutions require asserting place-based, Nuwu/Nuwuvi knowledge and agency in the response (Escobar 2001; Berry et al. 2017; Purcell 1998; Krause and Strang 2016; Loftus and Lumsden 2008, Jackson 2006). In their analysis linking biocultural survival and threatened water resources, Johnston and Fiske (2014) affirm that long-term stability in the hydrosphere requires the integration of social, cultural, and

environmental concerns across local, regional, and global systems that direct the use of the world's water. While spring developments remained quite the same from the Settler Era into the early USFWS Era, the next section outlines how springs management changed in the last $80+$ years under USFWS administration and the opportunities there-in for adaptive management, and describes current spring condition.

\subsection{U.S. Fish and Wildlife Refuge Era: 1936-today}

In this chapter, I illustrate that the current governance systems construe springs as measurable, confineable resources, as evidenced by their federal and state regulation, quantification of flow, and systematic development and 
maintenance to maximize and collect groundwater. The interviews I conducted (see questionnaire in Appendix A) provided a wealth of data about how springs have been historically developed and maintained by USFWS, and their purpose and limitations. My interviewees spanned 50+ years of first-hand experience as Managers of the Refuge, which provided insight into how springs management has changed both within the Refuge period as well as compared to the previous Eras. Interviewees' perceptions of springs ecological health as based on flow, the structure of maintenance and monitoring over time, and the threats springs face provided the scaffold for organizing the results and discussion that follow.

Based on interviews, the agency primarily values the upland springs to manage the Desert Bighorn Sheep, a charismatic species beloved by biologists, Euro-American-descendant hunters and outdoor recreationists, and Nuwu/Nuwuvi alike. Despite being in a protected area now managed as de-facto wilderness, extensive disturbance continues due to spring developments. Existing collaboration with tribes offers a possible avenue to integrate Indigenous perspectives into an adaptive, participatory future management.

\section{Federal Land Designation}

In 1936, U.S. President Franklin D. Roosevelt established the Desert Game Range via Executive Order 7373 for the conservation of Desert Bighorn sheep. Originally 2.25 million acres and under the joint direction of the Service and Bureau of Land Management (BLM), the administration, boundaries, and name of the Range incurred multiple changes over its 80 years of existence. At present, 
it totals 1.4 million acres with 654,000 acres under sole jurisdiction of the USFWS. In 1940, the US Air Force withdrew 846,000 acres of the Refuge from public access for use as an aerial bombing and gunnery range, now the former site of nuclear testing. Now known as the Nevada Test and Training Range (NTTR), a Memorandum of Agreement grants the Department of Defense primary jurisdiction over low elevation areas while the USFWS retains primary jurisdiction of the mountain ranges, where sheep primarily reside (USFWS 2009). According to interview with the Refuge Wildlife Biologist, this governance framework greatly limits the USFWS access to maintain springs in the closed area, which may only be aerially assessed for the presence of water by helicopter during annual sheep surveys.

According to interviews with multiple Refuge staff, humans minimally impacted since under the federal management by USFWS. Thanks to its status as proposed Wilderness, the landscape remains nearly roadless and protected from local development and intensive recreation. Proposed Wilderness status is not formally ratified by Congress and vulnerable to repeal, but stands as a main obstacle to the current U.S. Air Force proposal to withdraw up to 301,507 acres from the Refuge. This comprises half of what remains of the public DNWR and includes access to multiple springs in this survey. A decision is expected in 2021 (Lachman, et al. 2016). 
Springs and Sheep Conservation

Since its administration as a USFWS Refuge, the primary anthropogenic relationship with springs revolves around maintaining them for Desert bighorn sheep, which require water within a three-mile radius throughout the dry summer season. In addition to natural spring water sources, agency staff and volunteers built 29 human-made rainwater catchments (known as guzzlers) across the six mountain ranges to supplement water and expand the habitat (USFWS 2013). Springs and guzzlers critically maximize viable habitat and support healthy populations, but literature review and interviews with staff showed that for complex reasons, it is unclear exactly to what extent the spring developments are beneficial to populations. In the interview, the former Refuge Manager attested that local game hunters are passionate defenders of the Desert Bighorn sheep, and have played an active role in spring and guzzler developments on the Refuge for over four decades.

\section{USFWS Spring Development}

Under USFWS management, the conservation of bighorn sheep populations entailed the strategic maximization of water resources on the Refuge, for which controlling rights to groundwater was key. In 1936, the creation of the Refuge federally reserved those springs not yet appropriated for Refuge use. In the three decades that followed, the USFWS also acquired rights to eleven springs originally appropriated to private individuals by the state. DNWR archives hold 
records of appropriation for 25 springs in the Sheep and Las Vegas Ranges (USFWS Archives).

The former Refuge manager reported that springs most commonly occur at the base of a hill or slope, identifiable by the presence of hydrophytic vegetation or wetlands, saturated soil, stream flows and wildlife. Locating the springs required an intuitive ability to follow topographic contours and locate the water. This aspect of springs ecological knowledge is likely shared among land managers, settlers, and Nuwu/Nuwuvi.

Based on pedestrian surveys and interviews with the Refuge Archaeologist, The spring infrastructure make up the bulk of limited archaeological evidence from the USFWS era noted near springs. USFWS staff developed and updated springs using simple tools and materials. In the preceding Settler Era, private water rights owners made developments to the most reliable and accessible springs which the USFWS maintained and updated as needed. The installation of a spring box can drastically change the pooling of spring water and the structure of the aquatic and/or riparian community that may have existed where water naturally pooled (Sada et al. 2005). Other modification types involve piping water from the springhead into a trough, or into a storage tank that feeds a trough or a drinker with a float valve. By acquiring the rights from private holders, the USFWS gained more control over their development and maintenance, though the outcomes of improvements remained hit-or-miss due to a number of factors (Interviews, 2016; USFWS Archives).-Over time, the agency upgraded some developments with more durable and easy-to-maintain materials 
(Image 8). In some cases, such as Spring 8, the spring water stored in a tank is augmented with rainwater collection aprons or collection dams (Image 9). Many springs exhibit layers of modifications and improvements made over the years. Due to incomplete records and the fact that piping infrastructure is largely concealed below ground or thick vegetation, the specifics of past and existing modifications remains unknown for certain springs. Old, disconnected drinkers and pipes remain scattered around many springs. Other archaeological signs of USFWS activity include blinds formerly used in sheep surveys. I observed an unidentified debris ostensibly ejected from an aircraft near Spring 4, evidence of US Air Force activities nearby. Springs in need of particular updates or maintenance are listed in Table 12.

Image 8. Wooden boards cover the source where water is piped around 3oft from source to bathtub drinkers (above) at Spring 3, Sheep Mountains.

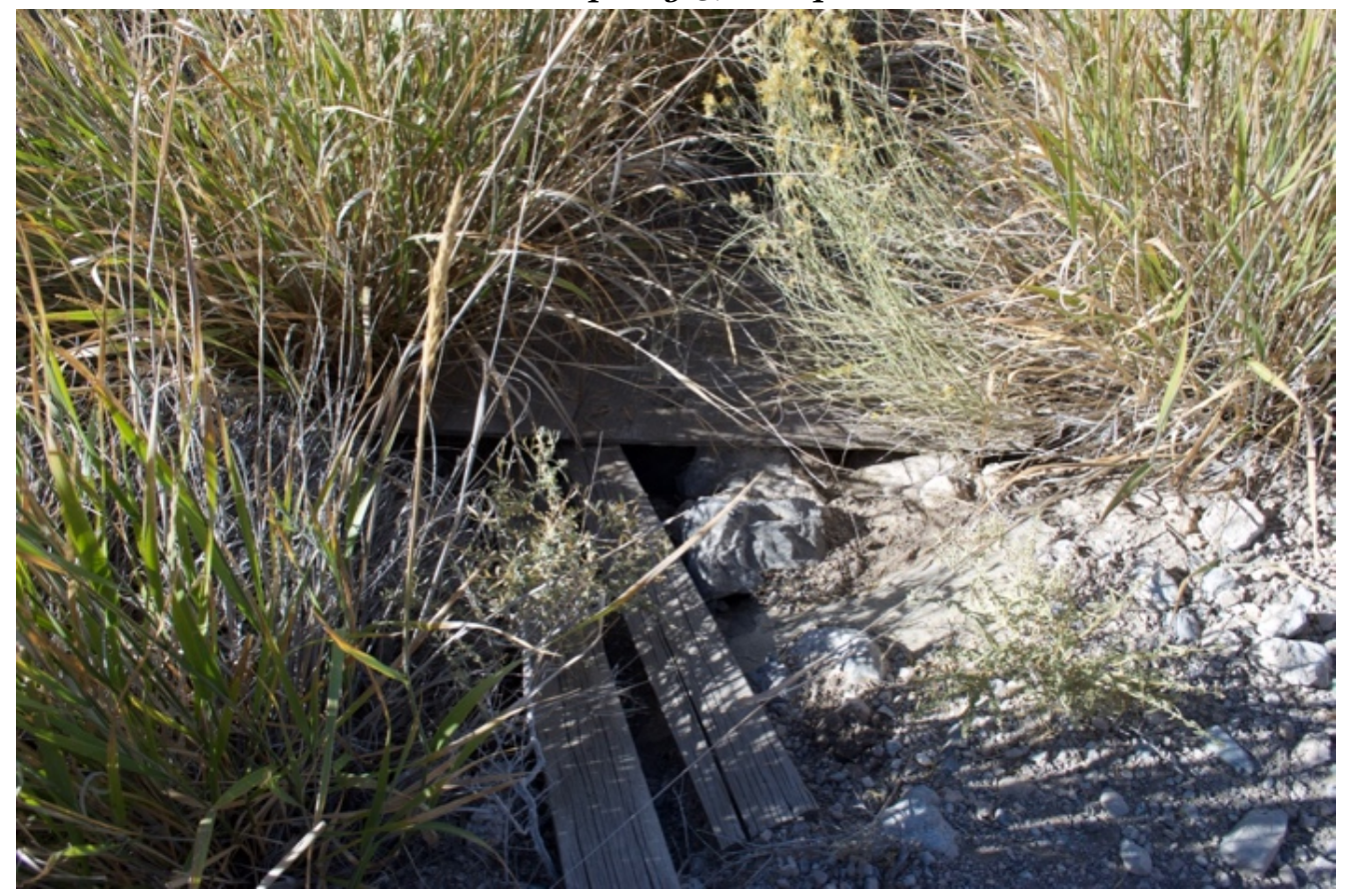


Image 9. Bathtub drinkers impound the diverted spring flow at Spring 3, Sheep Range

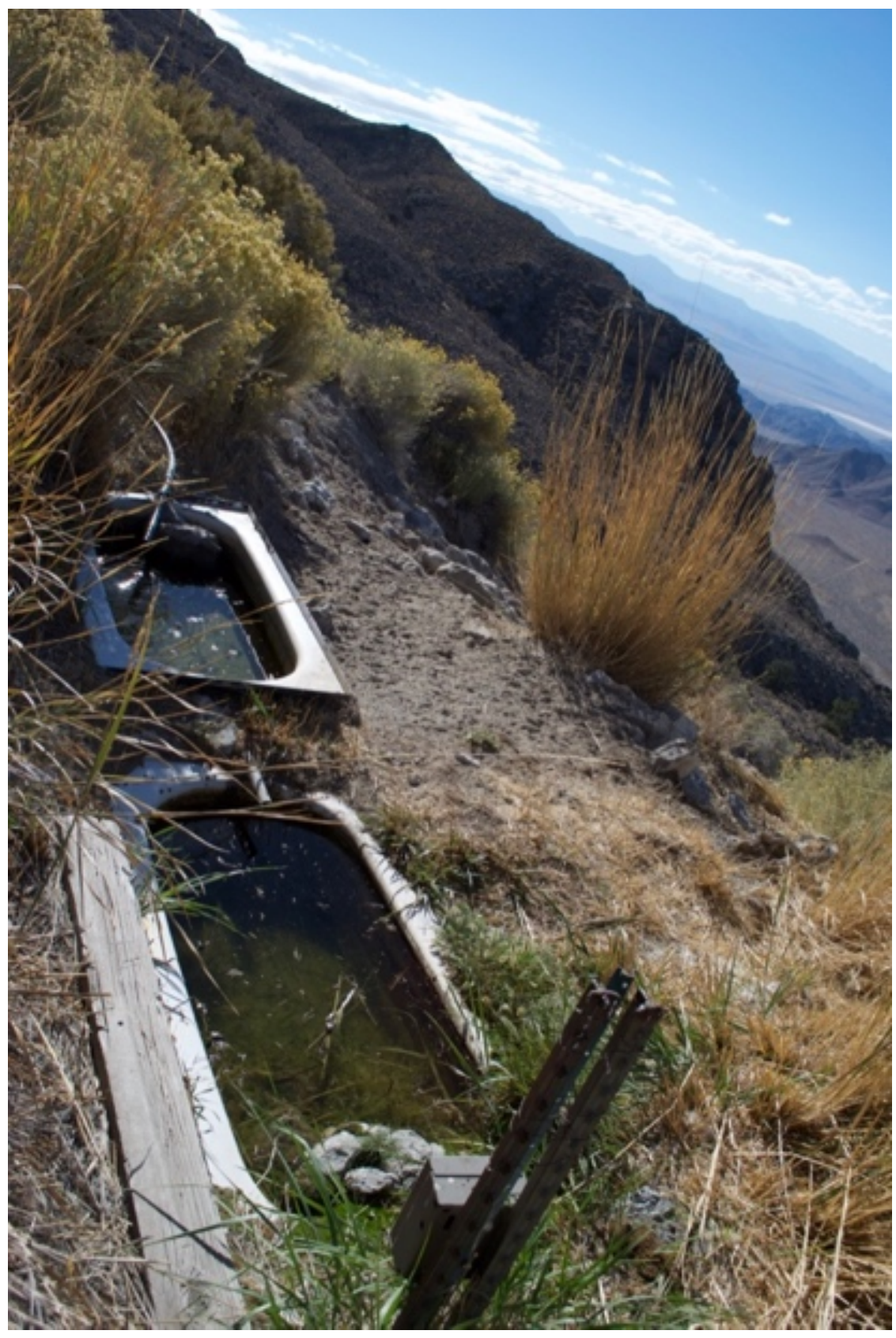


Image 1o. Tanks at Spring 8 store both spring water and rain water which are dispensed through two drinkers.

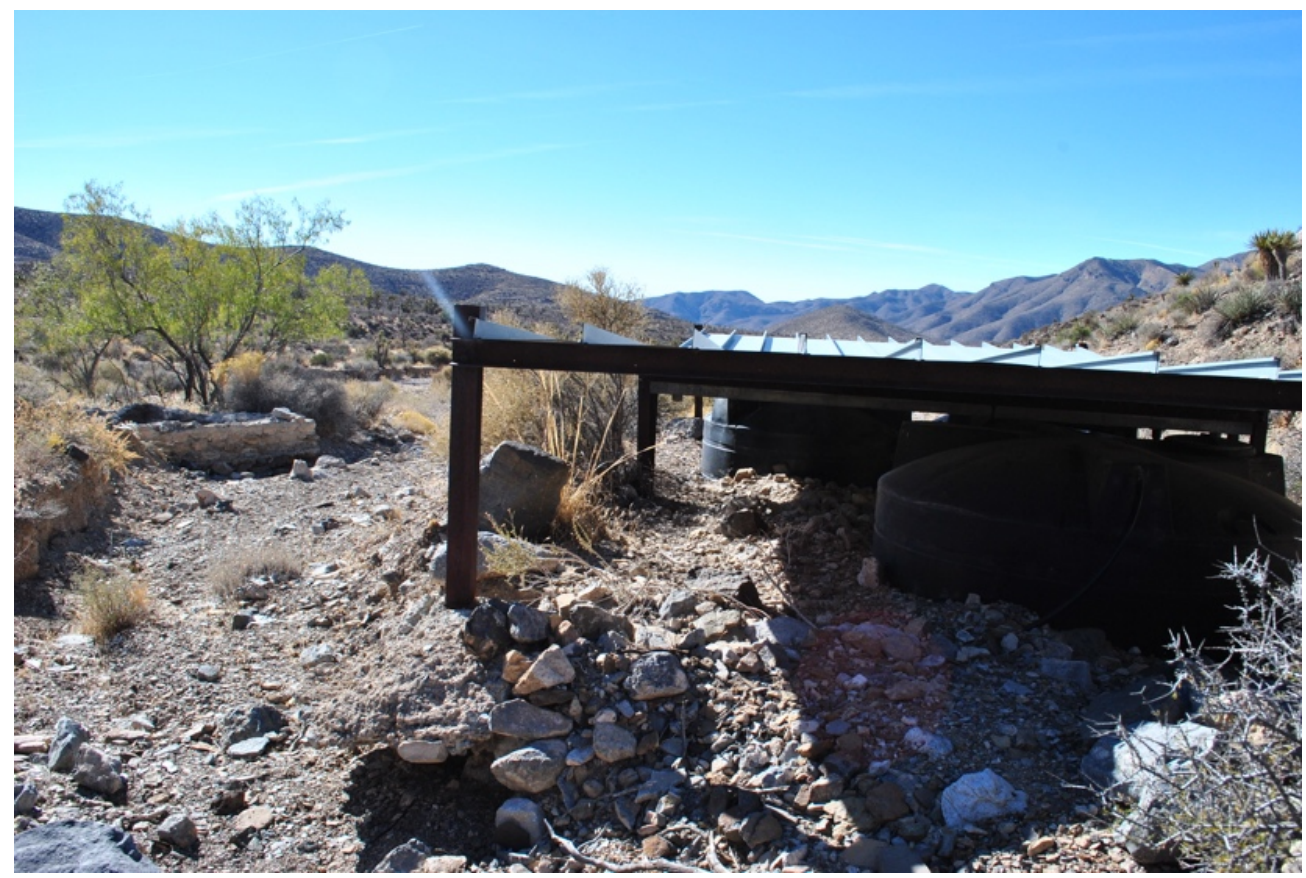

Table 12. Sample of Refuge springs that need work to improve their health and function (USFWS 2013).

\begin{tabular}{|l|l|}
\hline Spring & $\begin{array}{l}\text { Issues and improvements } \\
\text { needed }\end{array}$ \\
\hline Spring 8 & $\begin{array}{l}\text { Low flow, needs development } \\
\text { update. }\end{array}$ \\
\hline Spring 9 & $\begin{array}{l}\text { Caving in, needs development } \\
\text { update; remove old works }\end{array}$ \\
\hline Spring 5 & $\begin{array}{l}\text { Periodic removal of invasive } \\
\text { species; cutting cattails and } \\
\text { cocklebur; needs shade vegetation } \\
\text { to keep out cattails; needs periodic } \\
\text { snaking, horehound infestation at } \\
\text { site needs to be removed. }\end{array}$ \\
\hline Spring 2 & $\begin{array}{l}\text { Requires unclogging pipe from } \\
\text { headbox every few years. Good } \\
\text { bighorn water. }\end{array}$ \\
\hline Spring 3 & $\begin{array}{l}\text { Tub needs periodic vegetation } \\
\text { clearing water }\end{array}$ \\
\hline
\end{tabular}




\section{Spring Monitoring and Maintenance}

The interviews illustrate that monitoring and maintenance are the primary aspects of human-spring relationship under the USFWS spring management. These are carried out to track the health, use, and function of the spring developments via replicable metrics. Interviews with USFWS staff revealed that spring health from a wildlife management perspective revolves around having a maximum reliable flow, perennial availability of drinking water to wildlife, native vegetation for forage and habitat, and the absence of invasive species. Since 2014, the agency uses a standard inventory and monitoring protocol adapted from the level one Springs Survey Framework (Sada and Pohlmann 2002; Springs Stewardship Institute, n.d.). This entails collecting accurate geo-reference information, navigational directions, thorough photographic documentation, measuring flow, and noting invasive species, wildlife signs, and human impacts. Staff and researchers report that tracking spring condition, use, and function allows for historically grounded, efficient, and adaptive planning and management actions, and that such a systematic collection of data used to support long-term stewardship of springs (Sada and Pohlmann 2002).

According to the USFWS manager, the measurement of flow rates is a particularly important part of monitoring, done to ensure the volume of groundwater allotted in water rights is being fulfilled and utilized. I found that natural and anthropogenic factors impact spring flow rates on the Refuge, with variation occurring daily, seasonally, and across decades. Although springs exhibited significant temporal and spatial variability in flow, interviewees and 
Nuwu/Nuwuvi ethnographies noted that a drastic, sudden, or unseasonal decrease in flow volume and consistency was a common indicator of declining spring health across all eras. The literature illustrates the central role that consistent flow plays in ecological function and determining the intensity of disturbance (Lundquist and Cayan 2002, Lautz 2008, Gribovszki et al. 2010). The USFWS archives contain detailed, if incomplete chronological records of flow rates, as well as photographs, development and maintenance diaries, and wildlife usage at each spring.

In 2016, springs in the Las Vegas Range had significantly less volume than those in the Sheep Range. Interviewees explained that a successful spring modification resulted in an initial, temporary increase in flow, followed by a decline, which was evident in the decades of flow rate records. I measured during field surveys that the most reliable and high-flow spring in my sample (Spring 1, elev. $5,850 \mathrm{ft}$ ) measured $0.3 \mathrm{gal} / \mathrm{min}$, or $0.007 \mathrm{cfs}$. This constitutes $70 \%$ of its o.oo1cfs allotted by water rights documented in the archives. Of the six springs where flow measurements were possible, the next highest (and median) flow was o.003cfs (16oz/min), which represents $30 \%$ of allotted quantity. This is only a snapshot in time, but may signify that water developments are not effectively tapping flow, or/and lower water tables than in the past.

Due to the multitude of factors including springs modification and management practices, timing and quantity of precipitation, evapotranspiration, and uncertain hydrographic origin, it is difficult to pinpoint the cause and effect of spring flow variation over time. Furthering this research to consider spring 
variability at local and regional scales, and encompassing singular events, seasonal shifts, and geoclimatic eras into temporal analysis will present a layered understanding about individual springs within the landscape as whole. And raises important questions about the best way to manage these critical resources moving forward.

\section{Spring Vegetation in USFWS Era}

Healthy springs support patches of biodiverse vegetation and habitat that contribute to overall landscape biodiversity and resilience (Sada et al. 2005). According to Charlet.et al (2013), there are 731 known species of vascular plants from the public portion of the refuge. The results of my plant surveys are listed in Table 13. See Appendix D, for detailed discussion of non-native plants species around springs. Descriptive and statistical analysis of my spring botanical surveys indicated that species richness was generally lower at the spring head, with a mean of 2.55 taxa in each quadrat, compared to $10 \mathrm{~m}$ away, which had a mean of 3.57 taxa (two tailed paired ttest, $p$-value $=0.053$ ). While their difference was not quite statistically significant, these findings oppose normal trends for arid-land springs, where communities are typically more diverse at the source than surrounding uplands. My findings were consistent with Abella et. al's 2014 findings from a selection of DNWR springs that richness and cover were no greater, and sometimes lesser, closer to the source. Of the ten springs surveyed, Spring 2 was the most species-rich, with 19 total plant species recorded. The least species-rich spring was Spring 9, with a total of six species (Table 13). 
Wetland and riparian species, including plants, amphibians, and invertebrates around arid land springs require there to be water soaking the soil near the surface (Keleher and Rader 2008; Sada et al. 2005). Characteristic plants of Great Basin springs noted in this study (Patten et al. 2008) included wiregrass (Juncus mexicanus), noted at 80\% of high-elevation springs (Abella et al. 2014). Common reed (Phragmites australis) and cattails (Typha spp.) are others. The latter can be a nuisance for sheep management because they obscure the spring source and are periodically cleared to maintain open access to water. In line with Sinclair et al. (2018), I found that hillslope springs support more generalist species. I observed homogenous vegetation at most springheads in this sample, a trend also noted by land managers in the nearby Spring Mountains NWR (Spoon et al. 2013). This is a documented tendency for one species of riparian vegetation to take over in the absence of the small scale disturbance typical of pre-industrial societies (Merritt et al. 2010).

My findings similarly echo that while physical characteristics of spring types are generally associated with plant community structure and species distributions, springs ecosystems are highly individualistic and expanded inventory is needed to improve understanding of biodiversity for these little understood and changing systems (Sinclair et al. 2018). Interviewees reported this was likely due to the impoundment of ground water, trampling and predation by wildlife, and crowding from plants established at the source (e.g. rabbitbrush, Ericameria spp.). Ackerman et al. (2003) posits that plant diversity is lower than would be expected on the Refuge due to the absence of riparian 
vegetation because spring discharge is impounded in tanks, troughs, or drinkers. Wetland and riparian species, including plants, amphibians, and invertebrates around aridland springs require there to be water soaking the soil near the surface (Keleher and Rader 2008; Sada et al. 2005)

I recorded a total of eight distinct non-native species as part of the field surveys conducted in October 2016 (See Appendix C and D, pg. 169-175). Noxious weeds were not detected in the surveys and overall, infestation by non-natives was relatively minimal. Non-native species are a major challenge to aridland springs conservation, because they can crowd out native species, alter hydrology, local soil chemistry, and fire regimes, and reduce biodiversity. These findings contribute to tracking non-native species distributions at individual springs so that they may be kept in check. Analysis with linear regressions (Appendix D, pg. 170) indicated there was no relationship between elevation and species richness, nor, unlike trends observed in other Great Basin springs (Abele et al. 2013), between species richness and disturbance rating. This suggests that plant composition at Refuge springs is influenced by a number of other factors, such as aspect, slope, soil moisture and soil type, and the frequency and intensity of natural and anthropogenic sources of disturbance. More in-depth surveys measuring parameters such as structure, distribution, or cover of spring flora could yield more fine-grained information about how anthropogenic activities, spring developments, and setting influence spring flora within the DNWR landscape. 
Table 13. Plant species richness survey results: sample of ten Refuge springs

\begin{tabular}{|c|c|c|c|c|c|}
\hline $\begin{array}{l}\text { Spring or } \\
\text { Mountain } \\
\text { Range }\end{array}$ & $\begin{array}{l}\text { Species } \\
\text { richness (all) }\end{array}$ & $\begin{array}{l}\text { Native } \\
\text { species }\end{array}$ & $\begin{array}{l}\text { Non-native } \\
\text { species }\end{array}$ & $\begin{array}{l}\% \text { occurrence of } \\
\text { non-native } \\
\text { species in } 9 \\
\text { survey plots }\end{array}$ & $\begin{array}{l}\text { Total count of } \\
\text { vascular plants } \\
\text { observed during } \\
\text { survey }\end{array}$ \\
\hline Spring 1 & 13 & 10 & 3 & $67 \%$ & 40 \\
\hline Spring 2 & 19 & 16 & 3 & $78 \%$ & 36 \\
\hline Spring 3 & 9 & 7 & 2 & $44 \%$ & 22 \\
\hline Spring 4 & 9 & 5 & 4 & $89 \%$ & 23 \\
\hline Spring 5 & 10 & 6 & 4 & $100 \%$ & 23 \\
\hline Spring 6 & 14 & 13 & 1 & $11 \%$ & 35 \\
\hline Spring 7 & 8 & 6 & 2 & $44 \%$ & 18 \\
\hline Spring 8 & 15 & 13 & 2 & $22 \%$ & 23 \\
\hline Spring 9 & 6 & 4 & 2 & $22 \%$ & 13 \\
\hline Spring 10 & 18 & 16 & 2 & $44 \%$ & 30 \\
\hline $\begin{array}{l}\text { Sheep } \\
\text { Range } \\
\text { mean }\end{array}$ & $\begin{array}{l}12.33 \\
\text { (st.dev=3.8) }\end{array}$ & $\begin{array}{l}9.5 \\
\text { (st.dev=4.3) }\end{array}$ & $\begin{array}{l}2.83 \\
\text { (st.dev=1.6) }\end{array}$ & $67 \%$ & $\begin{array}{l}29.83 \\
\text { (st.dev=8.1) }\end{array}$ \\
\hline $\begin{array}{l}\text { Las Vegas } \\
\text { Range } \\
\text { mean }\end{array}$ & $\begin{array}{l}11.75 \\
\text { (st.dev=5.7) }\end{array}$ & $\begin{array}{l}9.75 \\
\text { (st.dev=5.7) }\end{array}$ & $\begin{array}{l}2 \\
\text { (st.dev }=0 \text { ) }\end{array}$ & $33 \%$ & 21 (st.dev=7.3) \\
\hline $\begin{array}{l}\text { All springs } \\
\text { mean }\end{array}$ & $\begin{array}{l}12.1 \\
\text { (st.dev=4.3) }\end{array}$ & $\begin{array}{l}9.6 \\
\text { (st.dev=4.5) }\end{array}$ & $\begin{array}{l}2.5 \\
\text { (st.dev=1) }\end{array}$ & $56 \%$ & $\begin{array}{l}26.3 \\
\text { (st.dev=8.6) }\end{array}$ \\
\hline
\end{tabular}


Summary of Spring Conditions and Disturbance under USFWS

Disturbance to springs during the USFWS era primarily stems from the alteration of spring habitats due to diversions and impoundment of spring water. Invasion from non-native species remains relatively minimal. No records are available about the condition of springs prior to their modification by development, and there are also no comparable, unmodified springs available to serve as reference. While the extent and persistence of impact to specific springs since settler contact is unknown, spring developments influenced the hydrology, vegetation, and habitat quality of springs (Charlet et al. 2013; Abella et al. 2014). Modifications at the spring head, the piping of water away from the source, and the impoundment of water typically reduce or eliminate surface flow and the subsurface seepage of water (Sada et al. 2001). These modifications exist in all springs surveyed. The post-development reduction of seepage and surface flow is considered severe in five of the springs, based on historical records indicating significantly different flow and discharge patterns, and the absence or decline of riparian vegetation. Possible reasons for this are: the efficient capture of spring discharge that might otherwise form a springbrook (e.g. Spring 6); blockage through botched development (e.g. Spring 9); the storing of water in tanks (e.g. Spring 8 and Spring 10), rather than letting it flow its natural course down a wash or open containment with allowed overflow, where it may support vegetation (e.g. Spring 1).

Anthropogenic disturbance to springs include the spring "improvement" works, which may destroy vegetation, compact soils, and reduce, or block off 
discharge by altering the structure of the bedrock. The relative paucity of riparian plant species present on the Refuge may be related to the extensive development of the springs (Ackerman et al. 2003). Reduction of surface flow and seepage also have broad negative impact on faunal species including amphibians and invertebrates (Bradford et al. 2015). Due to the lack of reference information prior to development, it is not possible to estimate what species have been lost or precisely how the ecosystem structure and processes would be today had they not been altered since contact. The relatively minimal infestation by exotic species, however, may also be a result of the reduction in surface flow from development. It is less than might be expected given that springs are typically resource rich and prone to invasion, and less severe compared to rates of invasion of other arid riparian systems, such as the widespread infestation of the SW by Tamarisk (Tamarix spp.)

Historical USFWS Management Practices and Nuwu/Nuwuvi Hydrological Knowledge

Notwithstanding the well-preserved archaeological record and physical landscape, Euro-American settlers and current federal land management displace Native practices and viewpoints from the dominant management regime on ancestral Nuwu/Nuwuvi lands. Following federal regulations in place (e.g. National Historic Preservation Act of 1966, National Environmental Policy Act of 1970, American Indian Religious Freedom Act of 1978, the Native American Graves Protection and Repatriation Act of 1990), the agency consults with 
Nuwu/Nuwuvi tribes about activities that may impact cultural resources and religious practices. Additionally, Desert NWR collaboration with the Nuwu/Nuwuvi Working Group includes consultation for spring restoration at Corn Creek and ethnographic research integrating Nuwu/Nuwuvi knowledge into Refuge stewardship plans and interpretative content for a number of visitor centers within the Desert NWR Refuge Complex (e.g. Spoon and Arnold 2012; Spoon et al. 2013). Through this span of time, Nuwu/Nuwuvi retained a rich body of knowledge about springs and hydrological management practices passed down generationally through oral traditions (Spoon et al. 2012a; Fowler 2012b; Wendel 2014). While Nuwu/Nuwuvi do not actively participate in springs management on public lands at this time, the traditional ecological knowledge they maintain today holds valuable insights into the practices that sustained the springs for thousands of years. Nuwu/Nuwuvi assert that water in these areas is unhealthy and needs to be in appropriate relationship to find balance (Wendel 2014; Spoon et al. 2015). As of 2020, plans for springs restoration combining Nuwu/Nuwuvi knowledge and Western approaches on DNWR are underway. I observed that while the agency protocols differ from traditional Nuwu/Nuwuvi knowledge of spring management, both groups converge around protecting Desert Bighorn sheep and ideals of limiting disturbance to springs and the surrounding environment. Agency consultants recognized that mechanically altering springs with piping, dredging, and bulldozing can have negative impacts on spring flow. Nuwu/Nuwuvi elders from the Las Vegas Paiute tribe (Wendel 2012) also indicate that when Euro-Americans tried to dig out a spring to 
increase the flow, it sometimes would stop flowing entirely. Nuwu/Nuwuvi explain that a spring can stop flowing because of improper/disrespectful use, lack of use, or because "it doesn't know you" (also in Spoon et al. 2013).

I found clear evidence for at least three cases of spring developments impeding rather than enhancing the flow of springs in the USFWS archival record alone. Interviews with USFWS staff indicate that interventions changed over time. Learning from unsuccessful developments and trial and error over eight decades, USFWS staff now aim to minimally manipulate springs when works are needed, and also strives to preserve natural conditions by making developments minimally obtrusive. Management leverages State and Federal legislation to protect wildlife habitat and also emphasizes relationship building including meaningful consultation with the Nuwu/Nuwuvi Working Group and local partnerships with conservation organizations and volunteers, such as the Fraternity of the Desert Bighorn. Interviews with Refuge staff indicated that thanks to a combination of local funding (eg. SNPLMA) and strong, established partnerships, there is potential and willingness to revise spring management practices and consider inclusive and experimental approaches to meet a wider range of cultural and ecological interests.

In conclusion, spring "management" in the current USFWS era refers to springs as resources that are used rationally, based on dominant knowledge of their role in wildlife habitat conservation. Rooted in Western dualistic ontology and positivism, this implies a separation between the knowing and the practices (Nadasdy 1999), in stark contrast to Nuwu/Nuwuvi-management which is an 
emergent, interactive relationship between sentient beings (Spoon et al. 2012c). In the USFWS era, springs management is practiced within the institutionalized, hierarchical, state sanctioned, framework of the federal agency (Lertzman 2009) and largely follows the flow of funding, wildlife biological science, and policy directives. Management leverages state and federal legislation to protect wildlife habitat and also emphasizes relationship building including meaningful consultation with the culturally affiliated tribes who form the Nuwuvi Working Group, and local partnerships with conservation organizations and volunteers, such as the Fraternity of the Desert Bighorn. Thanks to a combination of local funding (eg. SNPLMA) and strong, established partnerships, there is potential and willingness to revise spring management practices and consider inclusive

and experimental approaches to meet a wider range of cultural and ecological interests. In the section that follows, I synthesize the above findings from the USFWS era with the preceding Settler Era and Nuwu/Nuwuvi pre-Contact Era in my argument for the springs' historical ecology and its relevance to the political ecology of water.

\subsection{Synthesis of Historical Ecology Eras}

A look into the ecological history of the springs' landscape reveals significant changes in their form and function, and their culturally mediated role in human lives across three anthropogenic eras. I identified three major "eras" through which to trace the ecological history of springs over time and space: the 
Nuwu/Nuwuvi (pre-Contact) era, the era of Euro-American settlement, and the current era of USFWS management. These characterize distinct regimes of usage and management that resulted in documented or inferred impacts on the ecology of the springs in my sample. I link these regimes to socio-cultural, political, economic, and climatic factors exerting influence at various scales--- across the region, landscape, and/or localized to an individual spring. Table 14 recapitulates basic characteristics of the anthropogenic relationship to springs.

My findings support that significant ecological disturbance occurred following Euro-American settlement and development of springs, and that springs remain in an impaired state. This contributes current and historical data from small, hitherto unstudied upland springs to regional research on aridland springs, such as Sada and Lutz's (2016) longitudinal research revealing that 65\% Great Basin/Mojave Desert springs are moderately to severely disturbed.

The human- spring history of Desert National Wildlife Refuge varied across millennia. During pluvial periods, the Sheep and Las Vegas Mountains at the boundary of the Great Basin/Mojave Desert supported abundant spring-fed wetlands and streams. As a result of a naturally drying climate starting around $11,700 \mathrm{BP}$, the spring flow reduced significantly, and the wetlands and riparian species shrunk spatially around the source. In light of naturally occurring variation across the broader landscape, springs with perennial flow and minimal human intervention are exceptionally stable features that are controlled by geomorphic and climatic processes that have been relatively steady in the western US for the past several thousand years. 
Nuwu/Nuwuvi used and managed these springs at a localized scale limited to the ground surface. Historical and contemporary ethnographies from the last century indicate that Nuwu/Nuwuvi seasonal lifeways revolved around springs for subsistence across their Great Basin/Mojave Desert territory. Their relationships to these vital water sources hinged upon an adaptive knowledge system of stewardship and spiritual reverence, which entailed a moderated utilization of springwater and minimal, localized disturbance to springs. Evidence from Nuwu/Nuwuvi oral history, and examples from springs in comparable desert environments suggests that these small-scale disturbances, including the possible cultivation or tending of useful plants, would have contributed a network of resilient and biodiverse springs systems across millennia of climatic variation (eg. Alcorn 1981; Nabhan 2008; Maffi and Woodley 2010; Gadgil et al. 1993).

The springs landscape underwent a series of massive cultural shifts since the late $18^{\text {th }}$ century due to colonization, climate change, incorporation into the US nation and market economy, rapid urban and suburban growth, military presence and nuclear testing, and federal management under the Bureau of Land Management and most recently as a USFW Refuge. Each of these cultural, political, and climatological influences shaped human- springs dynamics and left their mark on the landscape. Patterns of land use and spring management shifted in response to regional economic and political drivers (mining, ranching, urban development and gambling, public lands conservation), changes in technology (the arrival of the railroad, electricity-driven groundwater pumping, horses, then 
helicopter use to develop inaccessible springs), and variations in climate (dry or wet periods, drought).

The Westward expansion justified by Manifest Destiny spurred the sociopolitical-economic transformation of the continent. Using violent, subversive attacks, Euro-American settlers displaced Nuwu/Nuwuvi communities from their lands and springs and drastically disrupted traditional lifeways and spring management. Settlers developed springs to survive within an extractive and consumptive framework mandated by the state-regulated Doctrine of Prior Appropriation to support their settlements and economic profit. This SettlerColonial tool continues to dispossess Indigenous peoples from water in their territories, as demonstrated by Andrew Curely's analysis of water settlements with Indigenous Nations in the Western US (2019). Even under the Winters Doctrine, meant to guarantee a measured quantity of water for Reservation communities (Bryan 2017), the Las Vegas Paiute Reservation (est. 1986) received only a fraction of their claim to adjudicated water rights through federal court (Kropf 1999). The intensive use of fragile ecosystems for livestock, and today, to maximize available water to Desert Bighorn sheep, entailed drastic modifications made to their form, function, and the aquatic and/or riparian biota they could otherwise support (Sada et al. 2005). This development and intensive use also counter Nuwu/Nuwuvi knowledge and practices, although some practices and ideals converge despite divergent epistemologies (Wendel 2012). Despite the extensive disturbance to springs documented across the region, studies suggest that restoration of some historical spring forms and functions are possible. 
Relational analyses of water, write Orlove and Caton (2010), reveal the intricacies of governance and politics in a context where water studies are habitually reduce water to an economic resource. It is urgent to challenge this common reduction of water, given the disastrous effects of current managerial regimes on bio-cultural health worldwide (Johnston 2013).

This study nests within a broader conversation about the political ecology of water: a critical lens on water crises examines the political dimensions of groundwater management narratives and their material and discursive effects (Demeritt 1994). As Clifford Geertz (1972) showed that water and irrigation traditions reveal the cultural and political dynamics of peoples with that of water, this Great Basin/Mojave Desert case study aims to make visible the social and material processes making up the "infrastructure" of springs management over time in a (for now) protected area (Krause and Strang 2016). While the literal spring development infrastructure from the Settler will remain long into the future, the springs lack structural traces of manipulation by Nuwu/Nuwuvi; yet, the substantial record of roasting pits and lithics-studded campsites illustrates how their lifeways developed to revolve around the springs with only small-scale disturbance.

By tracing the springs landscapes' historical ecology through something as essential as water, Berry et al. (2017) writes that we have the potential to reveal details about settler colonialism and Indigenous resistance, re-appropriation, and restoration that are not often evident in other histories. This study prompts questions about how the Indigenous sacredness of water can be protected within 
the dominant frameworks of Federal and State water laws (Bryan 2017) and joins a burgeoning international movement to integrate IEK in water planning and management (e.g., Jackson et al 2012, in Australia).

The following section presents selected results of this study most relevant to guiding next steps of springs management and restoration on the Refuge via a disturbance index, followed by the next chapter discussing threats to springs, applications, the unique contributions of this study, and finally, recommendations. 
Table 14. Characteristics of the anthropogenic relationship to springs

\begin{tabular}{|c|c|c|c|}
\hline \begin{tabular}{|l|} 
Human \\
relationship \\
to springs
\end{tabular} & \begin{tabular}{|l|} 
Nuwu/Nuwuvi \\
11, ooo BCE 1850 CE \\
(Spoon et al. 2015; Wendel \\
2014; Roberts and \\
Ahlstrom 2012) \\
\end{tabular} & \begin{tabular}{|l|} 
Settler $~ 1850-1936$ \\
(USWFS Archives, \\
NVSHPO n.d., Welden \\
2oo3., and others)
\end{tabular} & $\begin{array}{l}\text { USFWS 1936- } \\
\text { Present } \\
\text { (sourced from } \\
\text { USFWS archives; } \\
\text { interviews) }\end{array}$ \\
\hline $\begin{array}{l}\text { Cosmology/ } \\
\text { Spiritual } \\
\text { framework }\end{array}$ & 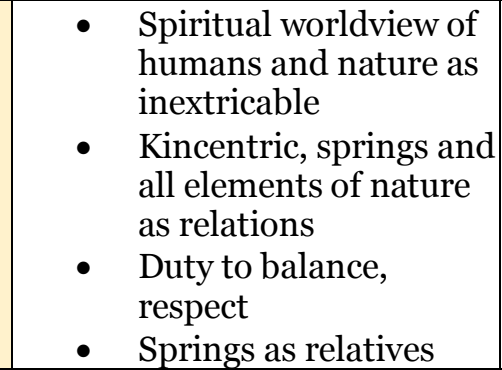 & $\begin{array}{ll} & \text { Christian } \\
\text { separation from } \\
\text { nature and duty } \\
\text { to exercise } \\
\text { dominion over } \\
\text { nature } \\
\text { - Springs as } \\
\text { Resources }\end{array}$ & $\begin{array}{ll}- & \text { Separation } \\
\text { from nature } \\
\text { - } & \text { Human agency } \\
\text { to protect and } \\
\text { manage wildlife } \\
\text { habitat } \\
\text { - } & \text { Springs as } \\
\text { Resources }\end{array}$ \\
\hline $\begin{array}{l}\text { System of } \\
\text { interaction }\end{array}$ & \begin{tabular}{ll|} 
- & Reciprocal, based in \\
supporting mutual \\
survival of humans and \\
springs
\end{tabular} & $\begin{array}{ll}\text { - } & \text { Consumptive and } \\
\text { extractive }\end{array}$ & - Consumptive \\
\hline \begin{tabular}{|l|} 
Political- \\
Economic \\
System \\
Property \\
Rights/ \\
Governance \\
System.
\end{tabular} & $\begin{array}{ll}\text { - } & \text { Subsistence; take what } \\
\text { you need, leave enough } \\
\text { for other life } \\
\text { - } \quad \text { Band-based occupation } \\
\text { and stewardship of } \\
\text { territory; flexible } \\
\text { shared use in } \\
\text { overlapping areas. } \\
\text { - } \\
\text { Maximizing survival }\end{array}$ & $\begin{array}{ll}\text { - } & \text { Market capitalist; } \\
\text { maximize } \\
\text { economic } \\
\text { potential of } \\
\text { springs } \\
\text { - } \\
\text { Private } \\
\text { ownership of } \\
\text { land } \\
\text { - } \\
\text { State-sanctioned } \\
\text { right to use water } \\
\text { - Maximizing } \\
\text { private } \\
\text { ownership, profit, } \\
\text { and political } \\
\text { control }\end{array}$ & $\begin{array}{l}\text { Federation; } \\
\text { ownership of } \\
\text { land held by the } \\
\text { government for } \\
\text { the public } \\
\text { Federally- } \\
\text { sanctioned } \\
\text { right to use } \\
\text { water } \\
\text { Maximizing } \\
\text { sheep } \\
\text { populations for } \\
\text { intrinsic } \\
\text { conservation } \\
\text { value and for } \\
\text { the public }\end{array}$ \\
\hline Practices & $\begin{array}{ll} & \text { Caring for/tending } \\
\text { - } & \text { Balancing practices } \\
\text { - } & \text { Use only what is } \\
\text { needed following } \\
\text { rituals demonstrating } \\
\text { proper spiritual } \\
\text { conduct and respect for } \\
\text { the interconnection of } \\
\text { all life }\end{array}$ & $\begin{array}{ll}- & \text { "Management" } \\
\text { - } & \text { Extractive } \\
\text { practices; water } \\
\text { for human use } \\
\text { and economic } \\
\text { development, } \\
\text { political control }\end{array}$ & $\begin{array}{ll}- & \text { "Management" } \\
\text { - } & \text { Extract water to } \\
\text { make more } \\
\text { available for } \\
\text { bighorn sheep } \\
\text { - Maintain water } \\
\text { rights }\end{array}$ \\
\hline
\end{tabular}




\subsection{Disturbance Index: Quantifying Sources of Spring Disturbance}

The following section presents selected results of this study that describe springs in their current state and will be most relevant to guiding next steps of springs management and restoration on the Refuge. The following section introduces the anthropogenic and so-called natural sources of disturbance which affect the springs. I start by presenting a disturbance index created for this study, in which I rate springs based upon the presence/absence of disturbance as a preliminary description to be developed into a more complex management tool.

\section{Sources of Ecological Disturbance}

Disturbance is a natural process in all ecosystems, but certain types or intensities cause changes in plant communities and declines in biodiversity and native species. Altering springs may impact their functions (e.g., hydrology, nutrient cycling) and can have broader implications across landscapes (Weissinger et al. 2012). Ecological disturbance is sometimes classified as environmentally occurring or anthropogenic. Environmental sources may be indirect effects of anthropogenic impacts. Table 15 below lists some of the common sources of disturbance observed in desert springs (Abele 2011). Some level of stress or flux from ecological disturbances is inherent and integral to ecosystem processes and function. The severity and scope of a stressor impacts whether a system is impaired, degraded or destroyed beyond the threshold of 
resilience or recovery (Holling 1973). Disturbance can be a source of multiple stressors to springs, for example, surface water diversions can alter a spring's physical integrity, create conditions that favor non-native aquatic species, and degrade habitat conditions for native riparian vegetation (Sada and Vineyard 2002; Abele 2011; Unmack and Minckley 2008). Untangling the effects of people is difficult. We know relatively little about long-term, pre-Contact regimes of resource use and management and the legacies they created for contemporary ecosystems (Armstrong et al. 2017). One reason for this lack of clarity is that traditional and locally based practices can be indistinguishable from natural ecological processes, and thus the histories of such interactions can often be difficult to detect in the archaeological and paleoecological records (Lepofsky and Lertzman 2008).

Table 15. Common sources of disturbance observed in Great Basin/Mojave Desert springs (Sada and Vineyard 2002; Abele 2011; Unmark and Minckley 2008).

\begin{tabular}{|c|c|}
\hline $\begin{array}{l}\text { Non-anthropogenic/ } \\
\text { environmental or indirect } \\
\text { anthropogenic sources }\end{array}$ & Anthropoge \\
\hline $\begin{array}{l}\text { - Seasonal drying } \\
\text { - } \text { Drought } \\
\text { - Fire } \\
\text { - Avalanche } \\
\text { - Scouring floods } \\
\text { - Harsh chemistry } \\
\quad \text { (inhospitable due to } \mathrm{pH}, \\
\text { - } \text { saline, sulfur, etc.) } \\
\text { - Temperature flux } \\
\text { Trampling by native } \\
\text { ungulates }\end{array}$ & $\begin{array}{l}\text { - Groundwater diversion: ground water } \\
\text { pumping, dredging, spring box capture } \\
\text { and piping to troughs, channelization, } \\
\text { etc. } \\
\text { - Impoundment of surface flow } \\
\text { - Pollution } \\
\text { - Introduction of non-native plants and } \\
\text { animals } \\
\text { - Ground disturbance from installation of } \\
\text { - spring developments } \\
\text { Trampling by humans and non-native } \\
\text { ungulates. }\end{array}$ \\
\hline
\end{tabular}


Image 11. Spring 9 (Las Vegas Range) chronically fills with sediment ("natural disturbance") due to how it was developed at the base of cliff wall

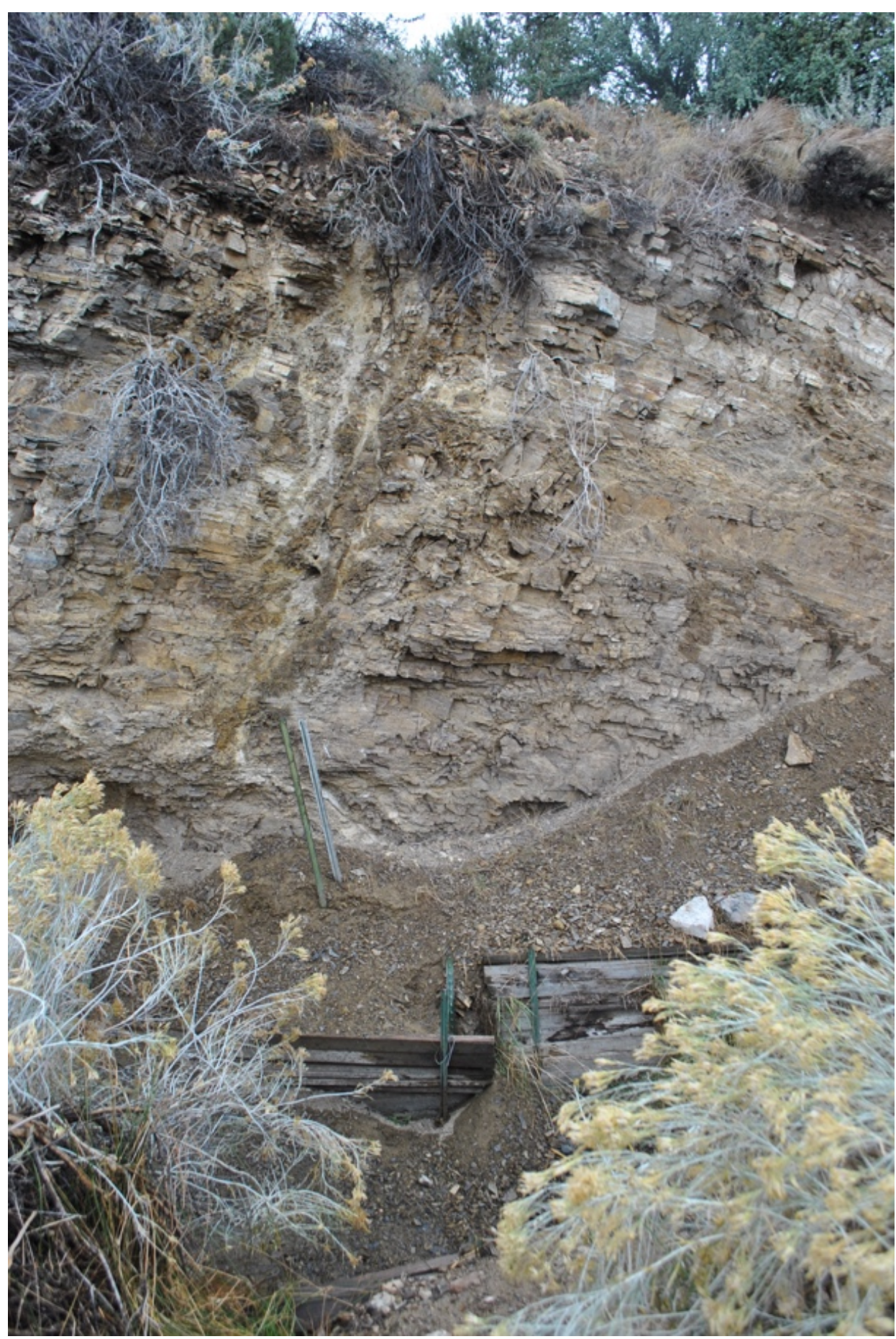


I designed a simple disturbance index to enumerate the presence/absence of major sources of disturbance at the time of the study (Abele 2011; Fleishman et al. 2006). This is a preliminary step to be followed by creating an index with weighted parameters attuned to specific on-site conditions. A more complex and nuanced analysis is needed to accurately rank these springs and point to rehabilitation priorities.

Parameters are listed in Table 16 and scores in Table 17. I based the parameters upon the Nevada Springs Conservation Plan, which measured four key attributes of spring viability (Abele 2011) and Fleishman et al. (2006)'s classification of springs disturbance in the nearby Spring Mountains. Given that hypothesizing the normal range of variation for these attributes was outside the scope of this study, I opted to simply enumerate the sources or drivers of disturbance that I observed. I did this from field data supported by archival records and the literature. I devised the comparative ranking inductively by cross-referencing field observations with analogous criteria from the literature. This helped approximate what qualified as minor, moderate, and severe disturbance for the Refuge springs. A score of 0-2 sources of disturbance suggests the spring ecosystem may be minimally disturbed, 3-4 suggests moderately, 5-6 suggests severely disturbed. This method is limited because quantity doesn't necessarily imply severity, and therefor the ranking among springs doesn't measure absolute differences. It aims to serve as a first step to a more nuanced analysis, which could identify rehabilitation priorities by enumerating the 
impacts of anthropogenic and natural sources of disturbance on the spring ecology.

In this preliminary assessment, all 10 springs were impacted by 4 to 6 sources of disturbance at the time of study. This qualified as moderately to highly disturbed, and is largely due to altered surface flow and resulting reduction of vegetation around the spring head. Of the 10 springs in the sample, six springs were moderately disturbed, and four were highly disturbed according to the rating system devised for this study. All four Las Vegas Range springs in the sample had bare ground around the spring basin, while only one of the six did in the Sheep Range. The presence of non-native species, while not classified as "noxious", may reduce native riparian habitat.

I found that the disturbance severity varied across springs of the Refuge. Springs in the Las Vegas Range presented signs of more severe disturbance, likely due to a combination of geographic and climatologic factors including a longer and more intensive period of exploitation due to their relative proximity and accessibility to settlers, full impoundment of spring water in the range with lower average precipitation, and a possible interconnection with over-drafted valley aquifers (Huntington 2010). Anecdotally, springs at lower elevations are less reliable. Interview participants and regional trends displayed in the literature (Sada and Lutz 2008) suggested that native species richness declined (including plants and invertebrates) following the development of springs for livestock and domestic use. This is due to the physical changes, including desiccation of the spring head due to water diversion and impoundment practices of settlers and 
continued by USFWS today. These developments reduce riparian habitat and if not properly maintained can reduce or block spring flow. Spring containers are periodically cleared of algae, sediment, and plants, which may preclude aquatic, wetland, or riparian communities to take hold. Invasion by non-native species is low, likely due to the springs' remote location and the Refuge's protected status. Low spring output and surface runoff may also contribute to the relatively low invasion of non-native species.

These phenomena reveal the complex interactions between anthropogenic influence and natural biological processes in dryland springs and highlight potential management trade-offs. Managing for maximum drinking water availability for Desert Bighorn sheep uniformly across all springs precludes local riparian habitat important for many other species (including birds, e.g., Chase and Geupel 2005) due to how these developments impound the flow. The upland springs in this survey compare similarly with the ecological condition of other springs throughout the region exhibiting moderate to high disturbance by historical and contemporary modifications to increase available water to wildlife or livestock. My preliminary findings reflect Sada and Lutz's (2016) longitudinal research from 2,256 other Great Basin/Mojave Desert springs. They found that: $83 \%$ of springs showed evidence of human disturbance, with $65 \%$ as moderately or highly disturbed. Recent studies by Keleher and Radar (2008) and Sada et al. (2005) illustrate that these levels of disturbance represent highly degraded, unhealthy ecosystems, with the condition of springs tending to decline over time. On the other hand, they report environmental disturbances including avalanches, 
fire, floods, and drying in a mere $3 \%$ of springs regionally, which I detected solely in one spring in this study (Sada and Lutz 2016). 
Table 16. Description of disturbance parameters and related ecological effects (Abele 2011; Fleishman et al. 2006)

\begin{tabular}{|c|c|c|c|c|c|c|c|}
\hline & $\begin{array}{l}\text { Total } \\
\text { sources of } \\
\text { disturbance } \\
(1=\min \\
6=\max )\end{array}$ & $\begin{array}{l}\text { Springhead } \\
\text { modified }\end{array}$ & $\begin{array}{l}\text { Flow } \\
\text { diverted } \\
\text { (above } \\
\text { and/or } \\
\text { below } \\
\text { ground) }\end{array}$ & $\begin{array}{l}\text { Flow } \\
\text { impounded } \\
\text { (partial or } \\
\text { total) }\end{array}$ & Bare ground/dry soil at spring head & $\begin{array}{l}\text { Introduced } \\
\text { /invasive } \\
\text { species }\end{array}$ & $\begin{array}{l}\text { Natural } \\
\text { factors }\end{array}$ \\
\hline $\begin{array}{l}\text { Parameter } \\
\text { description }\end{array}$ & $\begin{array}{l}\text { Score } \\
\text { indicates a } \\
\text { relative rank } \\
\text { of } \\
\text { disturbance } \\
\text { severity to } \\
\text { the springs } \\
\text { surveyed. It } \\
\text { does not } \\
\text { intend to } \\
\text { measure } \\
\text { disturbance } \\
\text { in absolute } \\
\text { terms. }\end{array}$ & $\begin{array}{l}\text { The } \\
\text { modification } \\
\text { of the spring } \\
\text { head by } \\
\text { digging, } \\
\text { dynamite, } \\
\text { tapping, or } \\
\text { installation } \\
\text { of a spring } \\
\text { box }\end{array}$ & $\begin{array}{l}\text { Channeling } \\
\text { spring } \\
\text { discharge } \\
\text { via a pipe } \\
\text { or other } \\
\text { from its } \\
\text { natural } \\
\text { course }\end{array}$ & $\begin{array}{l}\text { Storing } \\
\text { water; } \\
\text { limiting } \\
\text { surface flow }\end{array}$ & $\begin{array}{l}\text { A result of significant interruption of } \\
\text { surface discharge or seepage; no overflow } \\
\text { from impoundment; and/or disturbance } \\
\text { from construction of spring developments. } \\
\text { Excluding where greater environs are also } \\
\text { bare due to environmental factors, veg. } \\
\text { community, season, rocks, etc. } \\
\text { While I did not test water table depth, } \\
\text { archival records indicate springs produced } \\
\text { at least sufficient discharge to wet the soil } \\
\text { surface prior to their development. }\end{array}$ & $\begin{array}{l}\text { Introduced } \\
\text { species } \\
\text { recorded in } \\
\text { more than } \\
20 \% \text { of the } \\
\text { plots. }\end{array}$ & $\begin{array}{l}\text { Rock slides } \\
\text { Fire } \\
\text { Flood } \\
\text { Drying/ } \\
\text { drought }\end{array}$ \\
\hline $\begin{array}{l}\text { Ecological } \\
\text { effect }\end{array}$ & $\begin{array}{l}\text { Springs that } \\
\text { are highly } \\
\text { disturbed } \\
\text { may have } \\
\text { reduced } \\
\text { ecological } \\
\text { function } \\
\text { value and } \\
\text { host fewer } \\
\text { native } \\
\text { species. }\end{array}$ & $\begin{array}{l}\text { Changes the } \\
\text { structure, } \\
\text { outflow, and } \\
\text { species } \\
\text { assemblage } \\
\text { of the spring. } \\
\text { May } \\
\text { eliminate } \\
\text { habitat. }\end{array}$ & $\begin{array}{l}\text { Changes } \\
\text { the } \\
\text { structure, } \\
\text { outflow, } \\
\text { and species } \\
\text { assemblage } \\
\text { of the } \\
\text { spring. } \\
\text { May } \\
\text { eliminate } \\
\text { habitat. }\end{array}$ & $\begin{array}{l}\text { Changes the } \\
\text { structure, } \\
\text { outflow, and } \\
\text { species } \\
\text { assemblage } \\
\text { of the spring. } \\
\text { May } \\
\text { eliminate } \\
\text { habitat. }\end{array}$ & $\begin{array}{l}\text { Suggests significant degradation of } \\
\text { spring/riparian ecosystem as a result of } \\
\text { complete diversion and impoundment of } \\
\text { surface flow. Changes species assemblage } \\
\text { of the spring. May eliminate habitat. }\end{array}$ & $\begin{array}{l}\text { Compete } \\
\text { with native } \\
\text { flora; alter } \\
\text { water } \\
\text { availability } \\
\text { and fire } \\
\text { regime. May } \\
\text { eliminate } \\
\text { habitat. }\end{array}$ & $\begin{array}{l}\text { Changes } \\
\text { the } \\
\text { structure, } \\
\text { outflow, } \\
\text { and species } \\
\text { assemblage } \\
\text { of the } \\
\text { spring. } \\
\text { May } \\
\text { eliminate } \\
\text { habitat. }\end{array}$ \\
\hline
\end{tabular}


Table 17. Disturbance matrix scores. These include tallies of six possible common sources of disturbance.

\begin{tabular}{|c|c|c|c|c|c|c|c|}
\hline Spring & $\begin{array}{l}\text { Disturbance } \\
\text { Score }\end{array}$ & $\begin{array}{l}\text { Springhead } \\
\text { modified }\end{array}$ & $\begin{array}{l}\text { Flow } \\
\text { diverted }\end{array}$ & \begin{tabular}{|l|} 
Flow \\
impounded
\end{tabular} & \begin{tabular}{|l|} 
Bare \\
ground/dry \\
soil around \\
spring head
\end{tabular} & $\begin{array}{l}\text { Introduced } \\
\text { /Invasive } \\
\text { Species }\end{array}$ & $\begin{array}{l}\text { Natural } \\
\text { Factors }\end{array}$ \\
\hline \begin{tabular}{|l|} 
Spring \\
1
\end{tabular} & 4 & $\mathrm{X}$ & $\mathrm{X}$ & $\mathrm{X}$ & & $\mathrm{X}$ & \\
\hline \begin{tabular}{|l|} 
Spring \\
2
\end{tabular} & 4 & $\mathrm{X}$ & $\mathrm{X}$ & $\mathrm{X}$ & & $\mathrm{X}$ & \\
\hline \begin{tabular}{|l|} 
Spring \\
3
\end{tabular} & 4 & $\mathrm{X}$ & $\mathrm{X}$ & $\mathrm{X}$ & & $\mathrm{X}$ & \\
\hline $\begin{array}{l}\text { Spring } \\
4\end{array}$ & 4 & $\mathrm{X}$ & $\mathrm{X}$ & $\mathrm{X}$ & & $\mathrm{X}$ & \\
\hline $\begin{array}{l}4 \text { Spring } \\
5\end{array}$ & 4 & $\mathrm{x}$ & $\mathrm{x}$ & $\mathrm{x}$ & & $\mathrm{x}$ & \\
\hline \begin{tabular}{|l|} 
Spring \\
6
\end{tabular} & 4 & $\mathrm{X}$ & $\mathrm{X}$ & $\mathrm{X}$ & $\mathrm{X}$ & & \\
\hline \begin{tabular}{|l|} 
Spring \\
7
\end{tabular} & 5 & $\mathrm{X}$ & $\mathrm{x}$ & $\mathrm{x}$ & $\mathrm{X}$ & $\mathrm{x}$ & \\
\hline \begin{tabular}{|l|} 
Spring \\
8
\end{tabular} & 6 & $\mathrm{X}$ & $\mathrm{X}$ & $\mathrm{X}$ & $\mathrm{X}$ & $\mathrm{X}$ & $\mathrm{X}$ \\
\hline $\begin{array}{l}\text { Spring } \\
9\end{array}$ & 6 & $\mathrm{X}$ & $\mathrm{X}$ & $\mathrm{X}$ & $\mathrm{X}$ & $\mathrm{X}$ & $\mathrm{x}$ \\
\hline $\begin{array}{l}\text { Spring } \\
10\end{array}$ & 5 & $\mathrm{X}$ & $\mathrm{X}$ & $\mathrm{X}$ & $\mathrm{X}$ & $\mathrm{x}$ & \\
\hline
\end{tabular}




\section{CHAPTER 4：DISCUSSION AND CONCLUSION}

\subsection{Discussion: Threats to Refuge Springs}

The following thematic discussion presents three major ecological threats to springs identified in this study using the multidisciplinary lines of evidence assembled on the ten aridland springs. In addition to the disturbance caused by defunct or ineffective spring developments described above, interviews, field surveys, and literature review revealed climate change, regional groundwater extraction, and uncertain land management tenure as pressures to the continued function of Refuge springs. These threaten the continuation of spring flows and surface water upon which numerous wildlife depend on for drinking, as well as rare riparian vegetation habitat in this arid landscape. In the section that follows, I frame uncertain climate change impact predictions as both an extra-terrestrial and recently anthropogenic driver of spring ecology.

\section{Climate Change}

Human activity is now unprecedented in scope and agency behind climate change, sparking the demarcation of a new epoch dubbed the Anthropocene (Waters et al. 2016.) However, there is a need to distinguish between large-scale climate-forcing mechanisms and inherent small-scale climate variability affecting human lives, the latter of which can be both produced and mitigated by people (Lewis et al. 2015). 
Planetary change occurring at deep temporal scales include the periods of extensive glaciation alternating with warmer, interglacial intervals described by Milankovich (Berger 1988). A result of cyclical shifts in the Earth's orbit and tilt, these factors influence insolation and interact with large scale terrestrial phenomena to create a global climate pattern that, for the last 1 million years, consisted of 100,000 year glacial periods and inter-glacials typically lasting 10,000 to 30,000 years. Researchers suggest that our current warm interglacial will last considerably longer than precedented-- another 50,000 years-- because of the increased levels of atmospheric greenhouse gases resulting from human activity (Abe-Ouchi et al. 2013).

This comes with dire implications for both perched and regional springs. Climate changes expected in the Great Basin/Mojave Desert region from elevated greenhouse gasses and other terrestrial feedbacks include: altered timing and quantity of winter snows and spring rains, increases in the magnitude and frequency of storm events, and drought due to prolonged, drier and hotter summers. These changes will impact the recharge, supply, and timing of availability of groundwater, resulting in rapid declines in the water table and reduced discharge of springs fed by perched aquifers and basin- fill aquifers, which are dependent on local, seasonal precipitation. Perched springs, who directly rely on local precipitation to flow, may become dry year-round without sufficient snow pack. The larger regional aquifers contain "fossil water" that fell as rain up to ten thousand years ago, and would require thousands more to be replaced at even the higher rates of precipitation present at the turn of the last 
Epoch. However, the water recharge capacity of these aquifers is demonstrated to be permanently impaired due to compaction of pores in the rock from the severe over-mining that began in the 1940 .

The precise effects of climate change on Refuge springs are unclear due to complex and variable projections (Moreo et al. 2014). Land managers indicated that they expect climate change to first impact springs around the lower elevation of the Las Vegas Range due to limited local recharge from precipitation. The former Refuge manager with nearly 40 years' experience at the Refuge observed the link between years of light snow pack and reduced spring flows on the Sheep Range. Given uncertainty about future recharge and yields of aquifers, future regulation, and how springs will respond, more research is needed to understand how groundwater and spring flows in the Sheep and Las Vegas ranges will be impacted in the future, along with the surrounding plant communities and how this will impact this protected landscape more broadly (Stevens 2008). I included a basic overview of climate conditions to provide context and frame it as a major consideration of management. Since existing research on springs and climate change in Southern Nevada suggests complex, non-linear responses to drought and shifts in seasonal patterns of precipitation (Sada 2008), a comprehensive historical ecology of DNWR springs across various climatic periods will provide the reference conditions and baseline data needed to help understand and adapt to the impacts of early precipitation and a drying climate (Lempert and Groves 2010). 


\section{Groundwater Extraction}

The regional extraction of groundwater is another impact imposed since the Settler and USFWS eras. Broad scale appropriation and extraction of aquifers is part of Nevada's environmental legacy of exploitation for financial profit, alongside mining, ranching, the military and nuclear testing which helped define the Anthropocene, and rampant urbanization (Hulse 2009). The state regulations appear at odds with Nuwu/Nuwuvi traditional knowledge, and affect the Refuge springs directly in part because their sanctioned use required ranchers and now the USFWS to measurably develop them for beneficial use.

Formal hydrographic areas in Nevada were delineated systematically by the U.S. Geological Survey and Nevada Division of Water Resources in the late 1960's for scientific and administrative purposes. Their designate perennial yield and allocate water permits. (Nevada Division of Water Resources 2014). These basin regions have convoluted connected flow systems (Figure 6). Maxey and Eakin (1949) compared recharge and discharge estimates of individual basins and realized that many basins are not closed to groundwater transfer to or from adjacent basins. Today, most Nevada basins are fully appropriated and 45 of them are over-appropriated, which means that they are over-drafted on a yearly basis. Three of the 13 hydrographic basins of DNWR are over-appropriated and half the springs in this study lie within those over-appropriated basins that underlie the Refuge. Additionally, at least two springs in this sample may be affected by the severe overdraft of the Las Vegas Valley, one of three over- 
appropriated hydrographic basins (listed in Chapter 2, Table 7; see Figure 7 for map) (SNWA 2015b, NDWR 2014).

While much remains unclear about hydrogeological flows of water supply, the policy allows the over-appropriation of basins, and operates upon a false separation between surface and groundwater supplies. This legally enables groundwater extraction beyond what can be replenished, to the widely documented detriment of spring-dependent communities and future water availability, thus impacting the whole landscape. In the Great Basin /Upper Mojave Desert, groundwater extraction from regional aquifers via drilled wells negatively impact the quantity and quality of spring systems, and the biological resources and habitat associated with those springs. By decreasing water table depth, spring flows diminish or cease, also decreasing riparian vegetation and habitat (Patten et al. 2008). Impact studies of regional water extraction proposals (e.g. Patten et al. 2008, Naumburg et al. 2005) demonstrate that small declines in depth to the water table of less than 1m may cause spring wetland plant communities to change into upland transition zone. This can drastically alter spring ecosystems and the broader landscape, entailing a loss of species diversity. The encroachment of water-thirsty native vegetation, such as juniper (Juniperus spp.), a documented effect of cattle grazing, can also lower sub-surface water availability around a spring (Stevens and Meretsky 2008).

Groundwater from the Las Vegas Valley, which underlies five springs in the Refuge, has been in a state of overdraft since 1945, with extraction superseding its perennial yield by 350\% (SNWA 2011a, Pavelko et al. 1991). 
Water tables in the Las Vegas Valley plummeted more than 90 feet as a result of groundwater pumping in the area since colonization and settlement. This caused the drying of countless springs, subsidence of land, and permanently compromised the carrying capacity of the Las Vegas Valley aquifer, thus limiting the future availability of groundwater in the region (Pavelko et al. 1991).

Due to gaps in knowledge and inconsistent documentation of local hydrogeological dynamics, it is unclear how some of the Refuge springs interact with the regional aquifers being depleted by groundwater pumping in Las Vegas Valley and beyond (Pavelko et al. 1991; USFWS 2001; SNWA 2011a). Preliminary research shows potential inter-aquifer connectivity between the supposed perched aquifers of the Las Vegas Mountains and the Las Vegas Valley basin-fill aquifer (Naff et al. 1974; Winograd et al. 1975; Nevada Division of Water Resources 2014; Huntington 2010; Moreo et al. 2014, SNWA 2015a). Interviews with the current and former Refuge Managers, backed up by historical flow rates found in the USFWS Archives revealed that Refuge springs at the foothills of this range have steadily declined or ceased to flow as groundwater extraction has exponentially increased, though climate patterns and drought may also play a role in this correlation.

\section{Springs Pipeline}

What is more, the Colorado Flow System which underlies the eastern half of DNWR (pictured in orange in Figure 3) may be affected by the proposed 
Southern Nevada Water Authority groundwater pipeline (Figure 8 and Figure 9). The $\$ 15$ billion project is set to extract water from basins 300 miles to the north in anticipation that Las Vegas sources will falter by 2035. Environmental impact statements show this will negatively impact sensitive spring dependent communities, farming, and sacred sites (Mrowka 2014). A federal judge upheld the decision allowing SNWA to pump 84,000 acre-feet per year through this highly controversial pipeline (SNWA, Accessed October 2017). Though the process is currently being stalled in the legislature, the state is attempting a workaround by amending water policy to push the pipeline through. Denounced by the Center for Biological Diversity, among many as a water grab (Mrowka 2014), this is the latest enterprise by the powerful Las Vegas water agency created to centrally manage and strategically acquire access to evermore surface and groundwater since 1991. It is part of a wider pattern across the US West of creating dependencies on increasingly scarce water supplies due to overpopulation and subsidized development to promote economic growth (Welsh and Endter-Wada 2017).

Barbara Rose- Johnston (2003) writes that the centralization of resource authority comprises an increase in distance between those who arbitrate water resource allocation and management and those who experience the consequences. This proposal demonstrates the extent of the economic commodification of water for Las Vegas development and industry, and environmental alienation of its less-enfranchised value for ecological function, rural livelihoods, and Indigenous peoples. Some participants were aware of over- 
extraction of groundwater in the Las Vegas Valley and posited that this may contribute to the drying of lower elevation springs on the Refuge.

According to Wendel (2012), Nuwu/Nuwuvi affirm that because springs systems are connected, a spring can be influenced by events elsewhere on the landscape. Despite the inadequate consideration for how water sources are connected, Nevada water policy does converge with Nuwu/Nuwuvi knowledge in upholding that humans should use and maintain a relationship with water sources. Otherwise, Nuwu/Nuwuvi paradigms of right relationships with water, including water as sacred in situ, and springs as the home of spiritual beings, seem moot within the doctrine of beneficial use which guides the state sanctioned appropriation of water in Nevada.

Image 12. Window of Goshute (Western Shoshone) Reservation Headquarters reads, "SNWA: Sucks Native's Water Away. Stop Southern Nevada Water Association". Photo by Max Wilbert, 2014.

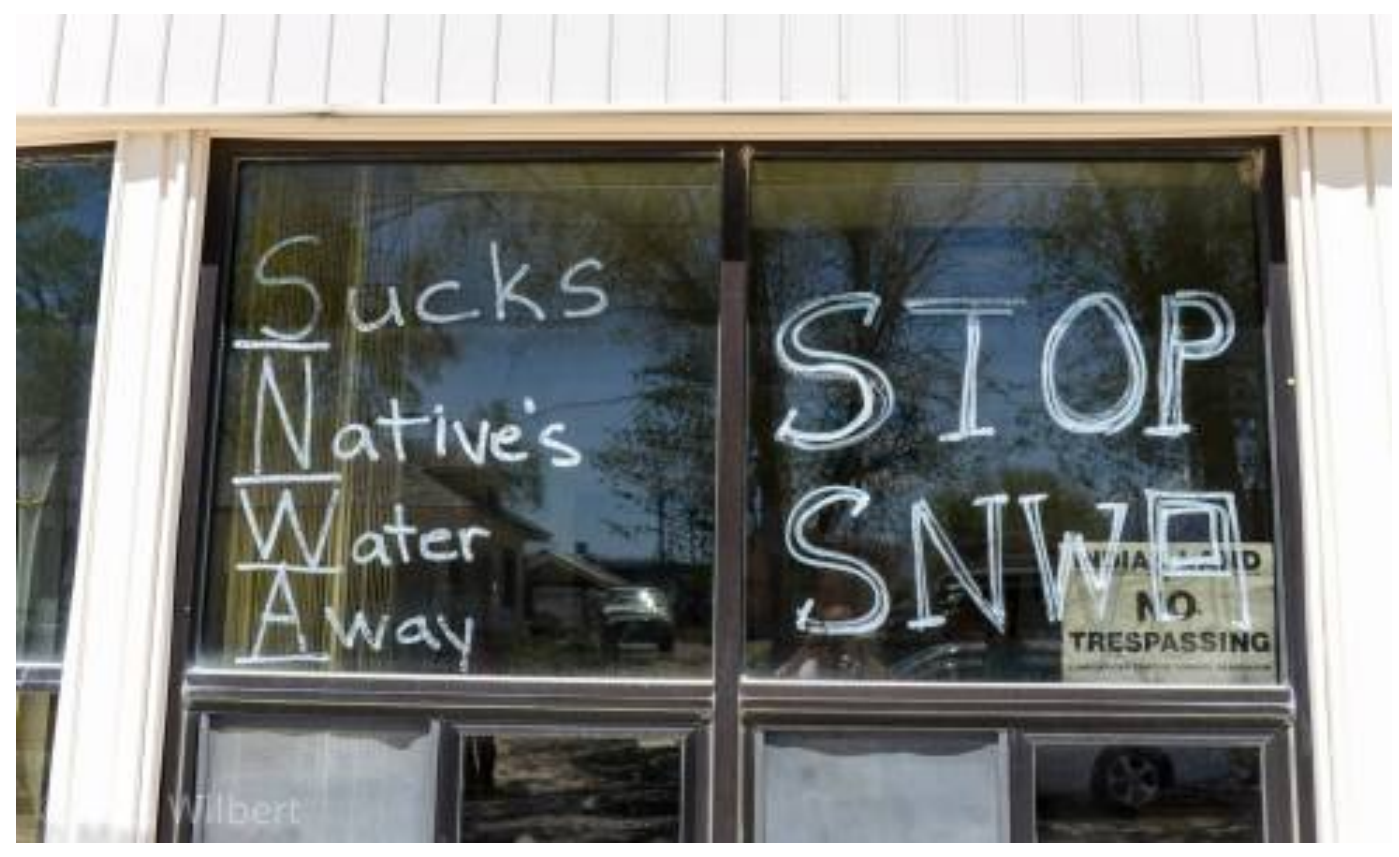


Figure 8. Regional hydrographic flow systems involved in the proposed Springs Valley Pipeline Project (adapted from SNWA 2011a).

Figure 9. Detail of regional hydrographic flow systems involved in the proposed Springs Valley Pipeline Project (adapted from SNWA 2011a).

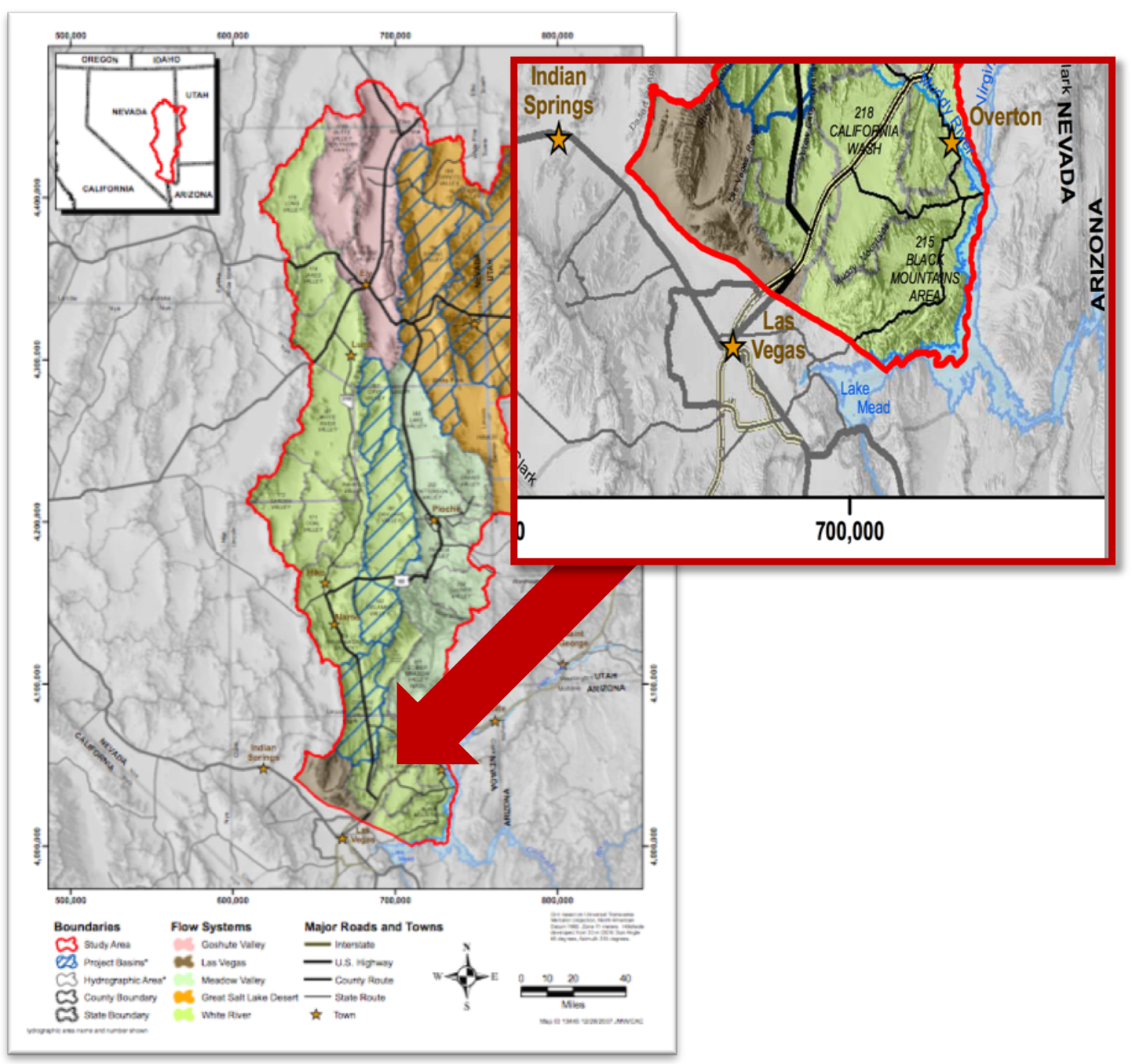


Maintaining regular records of flow rates is key to monitoring groundwater resources on the Refuge. Avenues to protect against groundwater extraction occurring outside the Refuge include protesting other water rights applications if Refuge resources may be affected, and seeking redress through the State Engineer's Office if existing water rights are infringed upon due to groundwater development (USFWS 2009). This paper urges the need for a fundamental redress of destructive water policies that allow far more water to be used than is available on a renewable basis. Laws regulating water rights allocations are inherently flawed. A major flaw of the first in use first in right water rights laws, as well as the negotiation of the Colorado Compact of 1922, is that it is based on an early twentieth century reality which could not have predicted with accuracy the level of growth or drought to follow. Further, surface and groundwater must be managed conjunctively, as 'one water.' Treating them as disconnected entities, a historical result of limited knowledge of hydrological systems, is no longer scientifically justifiable. Many of the world's largest rivers including the Colorado, no longer reach the ocean, because of excessive water use and overallocation, including overpumping of groundwater Famiglietti (2014).

\section{Land Withdrawal}

Finally, participants also listed the uncertainty of USFWS jurisdiction of over 200,000 acres to the as a threat to spring health (Lachman et al. 2016). Interviews revealed that the loss of access entailed by a proposed withdrawal to 
the Department of Defense also presents a real concern over continued management of springs for sheep and wildlife conservation.

\subsection{Discussion: Restoration and Adaptive Management}

This research adds to the increasing number of studies that demonstrate the utility of historical ecology to environmental planning by assessing the historical condition of wetland, riparian, and springs systems over time in context of natural and anthropogenic processes (eg. Stein et al. 2010, San Gabriel River watershed in southern California, USA; Bryan 2017; Buytaert et al. 2014; Rosenburg et al. 2005). Used to "reconstruct" the wetland mosaic prior to large scale modification, and to assess regions and wetland types that have been most impacted (Stein et al. 2010). This study adds further evidence for the widespread, dramatic extent of historical losses of wetlands and springs documented throughout the West, with other case studies and meta-studies estimate at 90\% (Stein et al. 2010 document 86\% since 1870; Stevens 2008).

\section{Restoration}

Studies urge for a careful consideration of roles of natural and anthropogenic disturbance in restoration of these dynamic and fragile springs ecosystems (Kodrick-Brown and Brown 2007; Erman 2002). Springs in their present form are structurally different-excavated, piped, and impounded. Their recent development trade a number of ecological functions and ecosystem 
services that would support a broader biodiversity (eg. nutrient and water cycling, habitat, Indigenous cultural value) for a greater volume of readily available drinking water which helps supports Bighorn sheep populations.

The ecological decline of springs is apparent today, but their historic structure and function are difficult to measure. Like other applied historical ecologies (eg. Stein et al 2010), this study identified the sources of springs degradation, the potential for restoration, appropriate candidates for spring naturalization and restoration, and suggests initial guidelines for re-establishing ecosystem function. The combined cultural and natural history of springs provides insight into the structure and function of undisturbed systems.

This inquiry into springs historical ecology with the aim of informing their effective management introduces many further questions:

- What ecosystem functions and species have been degraded or lost as a result of human activities or natural disturbance; can and should they be restored?

- To what extent do ecological function and ecosystem services of springs depend upon their morphology, and is each system truly unique?

- How beneficial are the spring developments to sheep populations in comparison to the human-made guzzlers, which may be easier to maintain?

- Which springs are good candidates for naturalization and restoration? 
- Looking at springs from various spatial and temporal scales incites the question, what scales are most important to consider going forward?

\section{Adaptive Management Linking Indigenous Communities to Federal Land}

This historical ecology of desert springs may be used as a basis for informing an adaptive management of springs that links Indigenous communities to federal land management. Ecologists and Nuwu/Nuwuvi alike maintained that restoration is necessary and should be spring specific, as each are unique and require tailored management. This corroborates with other studies advocating that restoration targets consider ecosystem function over form as a metric of success at both the site and landscape levels (Kittinger et al. 2015; Zelder and Kercher 2005; Erman 2002; Stein et al 2010). Scholars also argue for the necessity of a landscape-wide springs policy as well as regional and national, and (international) change on groundwater policies and the valuation of springs by science, lawmakers, and the general public (Ponder 2002; Kreamer et al. 2015, Sinclair 2018). Nuwu/Nuwuvi approach to restoration considers that traditional interaction with the land is necessary for ecological restoration of springs (Wendel 2012).

Robertson and McGee (2003) demonstrate how local knowledge of the history and ecology of wetland ecosystems in Australia can be a valuable resource in wetland rehabilitation projects. Intergenerational loss of information about the abundance of species can lead to shifting baselines, which have direct consequences for how species and ecosystems are managed (McClenachan et al. 
2012; Gagnon \& Berteaux 2009). As well as providing a source of historical information on species frequencies and distributions, they demonstrate how the use of TEK elicited through oral history serves also proved effective in enabling the values and concerns of local community and stakeholders to be articulated, increasing managers' understanding of the social context of the particular locality, which is fundamental to sound environmental decision-making (Robertson and McGee 2003).

This research forms a platform from which to interrogate how applied anthropology can facilitate the inclusion of Indigenous knowledge and promote collaborative, mutually-beneficial approaches to management. Through iterative learning, the results of this study may be put in conversation with Nuwu/Nuwuvi ethno-hydrological knowledge in future, participatory projects and restoration efforts (Spoon et. al 2013; Berkes et al. 2000)

Indigenous relationships to the environment emerge from worldviews that developed with and are inextricable from the landscape and adapted subsistence patterns (Berkes et al. 2000). Management regimes are constructed upon a settler-colonial paradigm that was superimposed upon an expanding, conquered territory (Krause \& Strang 2016). The ideology of a subordinate nature was used to legitimize the oppression of Indigenous peoples, women, and other subjugated groups, as well as the non-human world (eg. Plumwood 1993, 2005). As numerous scholars point out, this underlies many current ecological crises worldwide (eg. White 1967), and reinforces that environmentalism and social justice cannot be separated from one another (Veteto and Lockyer 2015). 
Adaptive management entails grappling with a present built upon injustice, and defining steps toward a future aligned with emerging social values and ecological realities. While not claiming to be a decolonized approach, this sets the stage to recognize the fruits of collaborative processes already in place and to identify opportunities to amplify power sharing within the existing federal land management systems (Nadasdy 1999). Wendel (2014) noted that while Nuwu/Nuwuvi and agency methods for observing and understanding ecological change stem from differing epistemologies, the conclusions they draw are quite similar.

\subsection{Conclusion}

This research provides a robust, in-depth, characterization of the ecological and anthropogenic histories of small, upland spring and seep ecosystems in a sparsely studied area. Results provided detailed, current information including current condition, disturbance, archaeology and vegetation, and establishes the historical ecological timeline and baseline of each specific spring. This study spans a broad temporal scale and weaves in many disciplines-findings voice not only the unique anthropogenic history and management needs of each specific spring, but also speak to a springs history across the Refuge landscape and desert Southwest region. Spanning a 10,000 year synopsis of hydrogeological, cultural, and political-economic forces influencing spring ecology spanning illustrate spring connection to forces 
involved at many scales, and adds to the growing body of research documenting drastic changes in aridland spring systems across the globe.

I examine the intersection of climatic, socio-cultural, and politicaleconomic drivers culminating in differing lifeways, practices, and perspectives of managing these habitats (Wendel 2012; Spoon 2013). I argue that the changes in scale and intensity of human influence within the springs landscape can be classified across the three broad "eras" of Nuwu/Nuwuvi pre-Contact, EuroAmerican Settler, and USFWS.

This analysis contributes a long-term perspective to larger issues of water use in aridlands, Indigenous and settler ecologies, and helps form a present baseline for springs that is cognizant of cultural history. I argue that Nuwu/Nuwuvi embodied a kin-centric, mutualistic relationship to springs; this supported an ethic of moderated use and small-scale disturbance through practices spanning physical and spiritual care, and may have fostered diverse and resilient spring systems. The traditional ecological knowledge highlighted in contemporary ethnographies with tribal members offers an alternative, culturally-grounded perspective on the crisis of groundwater depletion as a problem of human relational imbalance and neglect of springs and environment. My findings support that the purely utilitarian conception of springs by EuroAmerican settlers and resulting water policy resulted in significant ecological disturbance to springs, although flow may have been temporarily increased, and that springs remain in an impaired state. 
The Disturbance Index aggregates multiple observed human-and nonhuman derived impacts into a rating system that is used by USFWS to guide springs restoration priorities. It synthesizes the cumulative disturbance to springs over time and identifies that all 10 springs were moderately to severely disturbed, with those in the Las Vegas Mountains having a significantly higher disturbance than those in the Sheep mountains. I list the existing and future threats to springs identified through numerous lines of research and make recommendations for protecting and restoring culturally and ecologically valuable features and landscape.

A compilation of 98 previously recorded archaeological sites and the recording of 14 new sites substantiates (Table 8) the cultural significance of springs to Indigenous and Settler communities. This information may help protect archaeological sites as well as provide additional conservation interest to the springs. This research produced detailed surveys of vegetation communities surrounding 10 springs across two mountain ranges. These add insights to spring-upland vegetation gradients in varied settings spanning $2,000-8,000 \mathrm{ft}$ elevations, from Blackbush-Sage to Alpine communities. I produced a list of all known flora ever recorded at springs across the public and closed portion of DNWR. I compiled all noted invasive plant species at springs, present and past. This contributes a baseline for individual springs management as well as data to help understand springs biodiversity more broadly. In line with Sinclair et al. (2018), I found that hillslope and rheocrene springs support more generalist species, and that the absence of human interaction is likely to lower biodiversity. 
My findings similarly echo that while physical characteristics of spring types are generally associated with plant community structure and species distributions, springs ecosystems are highly individualistic and expanded inventory is needed to improve understanding of these little understood and highly threatened systems. In addition to their role in regional biodiversity and evolution, springs often function as keystone ecosystems playing disproportionally large roles in adjacent upland ecosystems (Perla and Stevens 2008), as well as within Indigenous cultures (Haynes 2008). As the Indigenous caretakers of the springs landscape, Nuwu/Nuwuvi are inextricable from the springs health and history, and hold wisdom for their persistence into the future (Spoon et al. 2013). Because springs are dynamic, complex, and individualistic, they require dialogue among disciplines that rarely communicate with each other (Kreamer et al 2005.) Based on my assemblage of data spanning three eras of human-spring relationship, I propose the following recommendations for engaging and protecting the joint cultural-ecological value of springs on the Refuge. 


\section{CHAPTER 5：RECOMMENDATIONS}

The success of spring stewardship depends on a thorough understanding of the natural and human factors that shape their physical environment and ecological communities. This study only begins to skim the surface in describing a few of the diverse ecological and cultural facets of these springs. Based on my research findings, I outline the following recommendations for the future management and restoration of springs of Desert National Wildlife Refuge springs and surrounding archaeological resources. In Table 18, I outline three potential management scenarios including their climatic, socio-cultural, and political economic drivers and outcomes on springs.

\subsection{Recommendation for Archaeological Resource Management at Springs}

Continue Recording Sites

- Conduct detailed surveys around springs, including sub-surface testing and roasting pit excavation, to enable additional learning about human-spring relationships across time. Archaeological resources comprise an important cultural heritage and are part of the springs landscape. They offer a unique window into their past and should be protected. Recording sites allows them to be recognized and 
protected. Maintaining cultural sensitivity and discretion about site locations, continuing consultation and partnership with Nuwu/Nuwuvi tribes, and educating the public are key to the conservation of the archaeological resources found at springs. Further, the inter-tribal response (observed by the author) to proposed Refuge land withdrawals highlight how the conservation of wildlife habitat and cultural resources can mutually support one another by bolstering the case for land conservation and stewardship. In addition to the uniquely large habitat the DNWR protects for Desert bighorn sheep, the Refuge's status as proposed wilderness, the Sheep Range Archaeological District, and contemporary ethnographic research help to substantiate the conservation value of this rich cultural landscape.

\subsection{Recommendations for Spring Management and Restoration}

Continue Beneficial Management Practices

\section{- Maintain existing water sources rather than developing new}

ones. Interviews and archival research indicated that from the perspective of wildlife management, water sources are sufficient and welldispersed across the Refuge, and there is no need for water developments in additional locations. Many of the spring developments, particularly those most visited by sheep or with storage tanks, should be maintained as 
they are. Fully passive management is not possible as developments need regular repairs and maintenance to ensure the provision of water to wildlife.

- Continue regular monitoring: Retain physical access to springs, staff, and funding to monitor and regularly maintain springs. Continue using a standardized monitoring protocol based on Spring Stewardship Institute level 1 inventory (Springs Stewardship Institute n.d.). Maintaining records of spring conditions and characteristics is key to establishing baselines and best practices for each spring (Sada and Lutz 2016). Recording flow rates is important to help detect aquifer depletion, especially in the Las Vegas Range, and should be ongoing. Monitoring and treatment for invasive species should continue.

\section{- Collect springs data and enter into the existing Springs}

Stewardship Institute global database, which is used by scientists, non-profit organizations, and federal agencies including the U.S. Forest Service for springs research and conservation purposes (Ledbetter et al. n.d.). A digital database could also be developed locally at DNWR to formally organize and inventory the Refuge springs data to facilitate their preservation and management. This would include comprehensive characterization of their ecology (for example: wildlife use and habitat, flow rates over time, soils, vegetation data), socio-cultural information including archaeology, and their development works and management 
plan. A database would also facilitate potential naturalization projects and their study over time.

- Continue to consider the unique condition and setting of each spring and approach restoration projects on a case-by-case basis.

- Other practices long employed by USFWS that were identified as beneficial include: maintain diagrams of development activities so future generations understand the alterations; place "rescue ramps" in troughs to prevent smaller wildlife from drowning, and update access and geo-reference information to springs.

Restoration Practices to Restore Natural Form and Function of One or More Springs

- Training: Sada and Lutz (2016) recommend managers and practitioners learn more about healthy and unhealthy spring ecosystems in the areas they practice. Because springs are rare and so few are ecologically healthy, this background is needed to identify and implement effective management techniques and goals that are site-specific and suited to the characteristics of each spring.

- Leave a Little: One low-input method to help improve native spring vegetation and habitat is employing the "leave a little" principle. This involves spring developments that partially capture flow and leave some 
surface flow or seepage, rather than fully diverting and impounding the discharge. At springs with strong flows, "leaving a little" may increase the spring's ecological benefits without significantly diminishing water supplies for wildlife. It can help address the absence of vegetation and diminished habitat caused by the piping and storage of spring water away from the source at certain springs (Fleishman et al. 2006). On the one hand, keeping pipes and tanks in good working order is important to avoid the unnecessary loss of water to evapotranspiration (Stevens 2008). This is particularly impactful at seeps that have minor surface flow regardless of development.

- Naturalization: Developments with chronic maintenance problems, that are also rarely used by sheep or are difficult to access would be candidates for naturalization. is option, suggested in the DNWR Spring and Water Development Management Plan (USFWS 2013), was also echoed by several study participants. Naturalizing would consist of removing spring developments and allowing the water to freely flow. Charlet et al. (2013) and Sada and Lutz (2016) argue that this will foster the growth of natural vegetation around the natural feature. While this might result in a smaller volume of perennial surface water available to wildlife, it could also help restore riparian plants and the diversity of habitat formerly lost due to the confinement of spring water. To form guidelines for naturalization, including determining the need for 
transplants and target spring morphology, more research is needed to understand how factors such as evapotranspiration, elevation, slope, aspect, and other factors that contribute to spring habitats could be understood to maximize the ecosystem value of springs while minimizing cost and maintenance.

- Remove defunct developments on chronically defective or low output springs by carefully discarding or recycling leaking or clogged pipes and tanks which impede natural discharge. Without the impoundment or blockage of water, groundwater can once again seep and pool to the surface, and in some cases form into a spring brook. Spring boxes at certain springs could be updated with more natural basins. These options have the benefit of reducing maintenance while improving wildlife access to water and fostering the restoration of riparian habitat that many species depend on. The amount of discharge, or volume of a spring is not an absolute factor in biodiversity or species abundance of aridland springs, meaning that even the lesser springs/seeps on Desert NWR can support a more diverse and resilient ecosystem (Sada and Lutz 2016). Sada and Lutz (2016) write that successful restoration programs of Nevada springs targeted their accurate functional aspects, which returned each spring to its naturally functioning condition. Unsuccessful programs have either used inappropriate methods or created habitats preferred by practitioners (e.g., pools) and changed the habitat and created conditions that support 
invasive species prevents restoration of healthy spring systems. While lessaltered springs tend to have a lower occurrence of invasive species, the activity caused by removing impoundments and/or rechanneling the water could create a new opportunity for introduced species (Fleishman et al. 2006). Ideally, invasive species would continue to be regularly monitored and managed to encourage the establishment of native vegetation. An iterative, experimental naturalization study aimed at restoring natural functions and vegetation could be undertaken at one or more Refuge springs (Stevens and Mertesky 2008).

\section{- Carry out collaborative/integrative/convergent approaches to}

naturalization: I recommend the process of naturalizing can be accomplished gradually over several years and would ideally involve partnerships with work crews to rehabilitate springs and pack out old materials (USFWS 2013). Many spring restoration plans emphasize stakeholder engagement and consultation with tribes and local communities (e.g. Springer and Stevens 2012). maintaining partnerships with local organizations to provide on-the-ground labor and create funding opportunities for contract work on springs information management, inventory, assessment, and restoration (Stevens 2008). For instance, restoration could take the shape of a citizen science "Adopt a Spring” program or a springs stewardship event. 
The uniquely strong relationship between USFWS and local $\mathrm{Nuwu} /$ Nuwuvi tribes is potentially fertile ground for a collaboration around spring naturalization. For example, spring naturalization may offer a stewardship and educational opportunity that links ecological and cultural revitalization and serves the public good. Possible co-management activities are identified in Wendel (2012) and three models of collaboration appropriate for different group sizes and activities are outlined in a collaborative stewardship plan (Spoon et al. 2013). Such stewardship activities could create a framework for intergenerational practice of Indigenous knowledge related to springs among Nuwu/Nuwuvi and USFWS land managers, and support connection and healing of native territories and histories, building o of successful events such as the annual "Gathering for Our Mountains" event at the Spring Mountains National Recreation Area. 
Table 18. Potential management scenarios characterized by domain

\begin{tabular}{|c|c|c|c|c|c|}
\hline $\begin{array}{l}\text { Potential } \\
\text { Future } \\
\text { Scenarios }\end{array}$ & $\begin{array}{l}\text { Climate/ } \\
\text { non-human } \\
\text { drivers }\end{array}$ & $\begin{array}{l}\text { Sociocultural } \\
\text { drivers: } \\
\text { worldview, } \\
\text { social } \\
\text { construction } \\
\text { of nature }\end{array}$ & $\begin{array}{l}\text { Political \& } \\
\text { economic } \\
\text { drivers }\end{array}$ & $\begin{array}{l}\text { Spring use \& } \\
\text { management } \\
\text { practices }\end{array}$ & $\begin{array}{l}\text { Spring ecology } \\
\text { \& } \\
\text { anthropogenic } \\
\text { impact }\end{array}$ \\
\hline \begin{tabular}{|l|} 
Collaborative \\
Adaptive \\
Management
\end{tabular} & $\begin{array}{l}\text { Climate } \\
\text { Change } \\
\text { scenarios } \\
\text { vary; } \\
\text { include } \\
\text { decreased } \\
\text { groundwate } \\
\text { r recharge } \\
\text { due to early } \\
\text { snowmelts }\end{array}$ & $\begin{array}{l}\text { Valuing } \\
\text { springs as } \\
\text { important } \\
\text { ecological } \\
\text { entities; } \\
\text { broader than } \\
\text { just a drinking } \\
\text { water source } \\
\text { for bighorn } \\
\text { sheep } \\
\text { Acknowledgin } \\
\text { g and } \\
\text { attempting to } \\
\text { repair colonial } \\
\text { legacy of } \\
\text { federal lands }\end{array}$ & $\begin{array}{l}\text { DOD expansion } \\
\text { denied by } \\
\text { Congress in } \\
2020 \\
\text { Dependent upon } \\
\text { funding and } \\
\text { social impetus } \\
\text { Collaborative } \\
\text { stewardship of } \\
\text { springs with } \\
\text { tribes } \\
\text { Progressive \& } \\
\text { experimental } \\
\text { land } \\
\text { management } \\
\text { agendas }\end{array}$ & $\begin{array}{l}\text { Apply } \\
\text { management } \\
\text { practices } \\
\text { determined/led } \\
\text { by } \\
\text { Nuwu/Nuwuvi, } \\
\text { including visits } \\
\text { by tribal } \\
\text { members } \\
\text { Spring } \\
\text { stewardship as a } \\
\text { tool for place- } \\
\text { based } \\
\text { transmission of } \\
\text { knowledge to } \\
\text { youth }\end{array}$ & $\begin{array}{l}\text { Bring the land } \\
\text { back in } \\
\text { balance } \\
\text { Tribal } \\
\text { revitalization } \\
\text { of place-based } \\
\text { culture } \\
\text { Possible } \\
\text { increase in } \\
\text { habitat and } \\
\text { biodiversity }\end{array}$ \\
\hline $\begin{array}{l}\text { Experimental } \\
\text { Spring } \\
\text { Rehabilitation } \\
\text { / Management }\end{array}$ & Varies & $\begin{array}{l}\text { Driven by } \\
\text { values of } \\
\text { biological } \\
\text { diversity and } \\
\text { inherent } \\
\text { rights of } \\
\text { nature/spring } \\
\text { s }\end{array}$ & $\begin{array}{l}\text { Springs remain } \\
\text { under USFWS } \\
\text { administration }\end{array}$ & $\begin{array}{l}\text { Spring } \\
\text { naturalization/ } \\
\text { Rehabilitation }\end{array}$ & $\begin{array}{l}\text { Status quo; } \\
\text { possibility of } \\
\text { applying } \\
\text { adaptive } \\
\text { management } \\
\text { practices } \\
\text { Possible } \\
\text { increase in } \\
\text { habitat and } \\
\text { biodiversity } \\
\text { Possible } \\
\text { decrease in } \\
\text { available water } \\
\text { to wildlife }\end{array}$ \\
\hline \begin{tabular}{|l} 
Land \\
Withdrawal \\
approved 2021
\end{tabular} & Varies & $\begin{array}{l}\text { Militarism } \\
\text { valued over } \\
\text { conservation }\end{array}$ & $\begin{array}{l}\text { Land } \\
\text { withdrawal from } \\
\text { USFWS Refuge } \\
\text { \& wilderness } \\
\text { designation for } \\
\text { military } \\
\text { operations }\end{array}$ & $\begin{array}{l}\text { Eight springs } \\
\text { removed from } \\
\text { USFWS system } \\
\text { and no longer } \\
\text { accessible for } \\
\text { management }\end{array}$ & $\begin{array}{l}\text { Eight springs } \\
\text { removed from } \\
\text { USFWS } \\
\text { system, } \\
\text { resulting loss } \\
\text { of function/ } \\
\text { drying due to } \\
\text { abandonment } \\
\text { and lack of } \\
\text { structural } \\
\text { maintenance }\end{array}$ \\
\hline
\end{tabular}




\section{REFERENCES}

Abele, S.L. (ed.)

2011. Nevada Springs Conservation Plan. Springs Conservation Plan

Working Group. The Nature Conservancy, Reno, NV. Cover photo:

Charnock Ranch, Nevada.

Abella, S. R., Craig, J. E., McPherson, S. L., \& Spencer, J. E.

2014. Watercourse-Upland and Elevational Gradients in Spring Vegetation of a Mojave-Great Basin Desert Landscape. Natural Areas Journal, 34(1), 79-91. doi:10.3375/043.034.0109

Ackerman, T.L., J. Bair, and A. Tiehm.

2003. A flora of the Desert National Wildlife Range, Nevada. Mentzelia, Number 7. Nevada Native Plant

Society, Reno.

Alcorn, J. B.

1981. Huastec noncrop resource management: Implications for prehistoric rain forest management. Human Ecology, 9(4), 395-417.

Armstrong, C. G., Shoemaker, A. C., McKechnie, I., Ekblom, A., Szabó, P., Lane, P. J., ... \& Gibbons, K. S.

2017. Anthropological contributions to historical ecology: 50 questions, infinite prospects. PloS one, 12(2), e0171883. 
Balee, William

2006. The Research of Historical Ecology. Annual Review of Anthropology. Vol. 35:75-98.

Banning, E. B.

2002. Archaeological Survey. New York: Kluwer Academic Press

Berkes, Fikret., Colding, J., \& Folke, C.

2000. Rediscovery of traditional ecological knowledge as adaptive management. Ecological applications, 10(5), 1251-1262.

Bernard, H. Russell

2011. Research Methods in Anthropology: Qualitative and Quantitative Approaches, third edition. New York: Altamira Press.

Berry, K.A., Jackson, S., Cohn, T.C. et al. 2017. Indigenous water histories II: water histories and the cultural politics of water for contemporary Indigenous groups. Water Hist 9, 1-7. https://doi.org/10.1007/s12685-017-0195-0

Blackstock, M.

2001. Water: A First Nations' Spiritual and Ecological Perspective. Journal of Ecosystems and Management, 1(1).

Boelens R, Chiba M, Nakashima D (eds). 2006. Water and Indigenous peoples, knowledges of nature 2 series.UNESCO Press, Paris

Bradford, David, Jef R. Jaeger, And Seth A. Shanahan 
2015. Distributional Changes And Population Status Of Amphibians In The Eastern Mojave Desert. Western North American Naturalist 65(4). Accessed Jan 2017. http://scholarsarchive.byu.edu/cgi/viewcontent.cgi?article $=1828$ \&context=wnan)

Brussard, Peter, David Charlet, and David Dobkin 2015. Great Basin- Mojave Desert Region. USGS Status and Trends of the Nation's Biological Resources, Volume 2. https://www.nwrc.usgs.gov/sandt/Great-bn.pdf

Bryan, Michelle 2017. Valuing Sacred Tribal Waters Within Prior Appropriation, 57 Nat. Resources J. 139.Available at: https://digitalrepository.unm.edu/nrj/vol57/iss1/6

Buytaert, W., Zulkafli, Z., Grainger, S., Acosta, L., Alemie, T. C., Bastiaensen, J., ... \& Foggin, M.

2014. Citizen science in hydrology and water resources: opportunities for knowledge generation, ecosystem service management, and sustainable development. Frontiers in Earth Science, 2, 26.

Cech, Thomas 2009. Principles of water resources: history, development, management, and policy. John Wiley \& Sons.

Chase, M. K., \& Geupel, G. R. 2005. The use of avian focal species for conservation planning in California. In Bird Conservation Implementation and Integration in the Americas: Proceedings of the Third International Partners in Flight 
Conference, General Technical Report PSWGTR-191. Albany, CA: USDA Forest Service (pp. 130-142).

Charlet David A., Patrick J. Leary Craig Westenburg. 2013. Vegetation and Floristic Survey Desert National Wildlife Refuge, Clark And Lincoln Counties, Nevada. Agreement No. 84550-9-Joo3 Between U.S. Department of The Interior Fish And Wildlife Service And College Of Southern Nevada. College of Southern Nevada Henderson, Nevada

Chief, K., Meadow, A., \& Whyte, K. 2016. Engaging southwestern tribes in sustainable water resources topics and management. Water, 8(8), 350.

Coughlan, M. R., \& Petty, A. M.

2012. Linking humans and fire: a proposal for a transdisciplinary fire ecology. International Journal of Wildland Fire, 21(5), 477-487.

Crumley, Carole

a.1994. Epilogue. Pp. 239-240 in C.L. Crumley (ed.), Historical Ecology: Cultural Knowledge and Changing Landscapes. Santa Fe: School of American Research Press.

b.1994. The ecology of conquest: contrasting agropastoral and agricultural societies' adaptation to climatic change In Crumley C, editor. Historical Ecology: Cultural Knowledge and Changing Landscapes. Santa Fe: SAR Press. pp. 183-201

Crumley, Carole 2014. What is Historical Ecology? Cultural Landscapes. 
http://www.hercules-

landscapes.eu/blog.php?what_is_historical_ecology\&id=10

. Accessed Oct. 2017.

Deur, Doug, \& Confer, D.

2012. People of Snowy Mountain, People of the River: A Multi-Agency

Ethnographic Overview and Compendium Relating to Tribes Associated with Clark County, Nevada.

Egan, D., and E. A. Howell, (eds).

2001. The historical ecology handbook: a Restorationist's guide to reference ecosystems. Island Press, Washington, D. C., USA.

Eliade, Mircea

1958. Patterns in comparative religion. University of Nebraska Press, Lincoln, Nebraska.

Enzel, Y., Wells, S. G., \& Lancaster, N. (eds.). 2003. Paleoenvironments and paleohydrology of the Mojave and southern Great Basin deserts. (Vol. 368). Geological Society of America.

Erman, Nancy

2002. Lessons from a long-term study of springs and spring invertebrates (Sierra Nevada, California, USA) and implications for conservation and management. In Conference proceedings. Springfed Wetlands: Important Scientific and Cultural Resources of the Intermountain Region, Las Vegas, NV. 


\section{Escobar, Arturo}

2001.Culture sits in places: reflections on globalism and subaltern strategies of localization. Political Geography.20:139-174

Faunt, Claudia, Frank A. D’Agnese, and Grady M. O’Brien.

n.d. Hydrology. In: Death Valley Regional Groundwater Flow System, Nevada and California- Hydrogeologic Framework and Transient Groundwater Flow Model. Edited by Wayne R.

Belcher and Donald S. Sweetkind.

Famiglietti, J. S.

2014. The global groundwater crisis. Nature Climate Change, 4(11), 945.

Fiero, William

1975. Hydrogeology of Corn Creek Springs, Clark County, NV. http://catalystarchitecture.com/pdc/CA_GRAPHICS/RFP-RFQSOQ/CORN_CREEK/oo_RFP\%20Appendix/Appendix\%20L\%201975 _Hydrogeology_Corn\%2oCreek\%2oSprings.pdf

Fleishman, E., Murphy, D.D. \& Sada, D.W. 2006. Effects of Environmental Heterogeneity and Disturbance on the Native and Non-native Flora of Desert Springs. Biological Invasions. 8: 1091. https://doi.org/10.1007/s10530oo5-7564-9

Foster, David, F Swanson, J Aber, I Burke, N Brokaw, D Tilman, A Knapp 2003. BioScience 53 (1), 77-88.

Fowler, C.S. and D.D. Fowler 
1990. A history of wetlands anthropology in the Great Basin. Pages 516. In, J.C. Janetski and D.B. Madsen (eds.). Wetland Adaptations in the Great Basin. Brigham Young University, Museum of Peoples and Cultures Occasional Papers No. 1

Fowler, Catherine S.

2002. What's In A Name? Some Southern Paiute Names for Mojave Desert Springs as Keys to Environmental Perception. Conference Proceedings. Spring-fed Wetlands: Important Scientific and Cultural Resources of the Intermountain Region. Accessed Feb 23rd 2016. https://www.dri.edu/ images/stories/conferences_and_workshops/spring-fedwetlands/spring-fed-wetlands-fowler.pdf

Fowler, Catherine S. 2012a. Water Flows Through Here: Moapa and Pahranigat Southern Paiute Culture in the Late 19th Century. Archaeological Report No. 07-28B, HRA Inc., Conservation Archaeology, Las Vegas.

2012b. Facing Snow Mountain: Las Vegas-Pahrump-Desert Southern Paiute Culture in the Late 19th Century. Archaeological Report No. 07-28, HRA Inc., Conservation Archaeology, Las Vegas.

Gadgil, M., Berkes, F., \& Folke, C.

1993. Indigenous knowledge for biodiversity conservation. Ambio, 151156. 
Gagnon, C., \& Berteaux, D.

2009. Integrating Traditional Ecological Knowledge and Ecological

Science: A Question of Scale. Ecology and Society, 14(2). Retrieved from http://www.jstor.org/stable/26268305

Geertz, Clifford

1972. The wet and the dry: traditional irrigation in Bali and Morocco. Hum Ecol 1(1):23-39

Geggus, Yarrow and Jeremy Spoon 2018. History, Ecology, Restoration, and Management of Natural Springs in Desert National Wildlife Refuge. Deliverable Report prepared for the Desert National Wildlife Refuge Complex, USFWS.

Grimm, N. B., Chacon, A., Dahm, C. N., Hostetler, S. W., Lind, O. T., \&

Starkweather,

P. L. WA Wurtsbaugh.

1997. Sensitivity of aquatic ecosystems to climatic and anthropogenic changes: the Basin and Range, American Southwest, and México. Hydrological Processes 11: 10231041. Hydrological Processes, 11, 1023-1041.

Haynes Jr, C. V. 2008. Quaternary cauldron springs as paleoecological archives. Aridland springs in North America: ecology and conservation. University of Arizona Press, Tucson.

Hulse, J. W.

2009. Nevada's Environmental Legacy: Progress Or Plunder. University of Nevada Press. 
Huntington, Jena.

2010. Section 6. Conceptual Understanding and Groundwater

Quality of the Basin-Fill Aquifer in Las Vegas Valley, Nevada.

https://pubs.usgs.gov/pp/1781/pdf/pp1781_section6.pdf

Holling, C.S.

1973. Resilience and Stability of Ecological Systems.

Annual Review of Ecology and Systematics 4:1, 1-23.

Ingerson, A. E.

1994. Tracking and testing the nature/culture dichotomy in practice In:

Crumley L, editor. Historical Ecology: Cultural Knowledge and Changing Landscapes. Santa Fe: School of American Research Press; 1994. pp. 4366.

Jackson, S.

2006. Compartmentalising culture: the articulation and consideration of Indigenous values in water resource management. Australian Geographer, 37(1), 19-31.

Jackson, S. T., \& Hobbs, R. J. 2009. Ecological restoration in the light of ecological history. Science, 325(5940), 567-569.

Jepson Flora Project

2016. The Jepson Herbarium. University of California, Berkeley. https://ucjeps.berkeley.edu/eflora/eflora_display.php?tid=13060

Johnston Barabra Rose and Shirley Fiske 
2014. The precarious state of the hydrosphere: why biocultural health matters. WIREs Water 1:1-9

Johnston, Barbara Rose

2003. The Political Ecology of Water: An Introduction, Capitalism Nature Socialism, 14:3, 73-90, DOI: 10.1080/10455750308565535

Keleher, M.J. and R.B. Radar 2008. Dispersal limitations and history explain community composition of metaphyton in desert springs of the Bonneville Basin, Utah: A multiscale analysis. Limnology and Oceanography 53:1604-1613.

Kelly, Isabel

1971. Southern Paiute Ethnography. University of Utah Press. Based on 1933-34 manuscripts.

Kelly, Isabel., Fowler, C.S. and d'Azevedo, W.L., 1986. Handbook of North American Indians. Vol. 11: Great Basin.

Kittinger, J. N., McClenachan, L., Gedan, K. B., \& Blight, L. K. (Eds.). 2015. Marine historical ecology in conservation: Applying the past to manage for the future. Univ of California Press.

Knack M. C.

2001. Boundaries Between: The Southern Paiutes, 1775-1995. University of Nebraska Press.

Koch, A., Brierley, C., Maslin, M. M., \& Lewis, S. L. 
2019. Earth system impacts of the European arrival and Great Dying in the Americas after 1492. Quaternary Science Reviews, 207, 13-36.

Kodric-Brown, A., \& Brown, J. H.

2007. Native fishes, exotic mammals, and the conservation of desert springs. Frontiers in Ecology and the Environment, 5(10), 549-553.

Krause F, Strang V.

2016. Thinking relationships through water. Soc Nat Res 29:633-638

Kreamer, D. K., Stevens, L. E., \& Ledbetter, J. D.

2015. Groundwater Dependent Ecosystems-Science, Challenges, and Policy Directions. In: Groundwater: Hydrogeochemistry, Environmental Impacts and Management Practices.

Kropf, R. L.

1999. Basin-Wide Adjudications in the West: What Works, What Doesn't?. LeCompte, M., \& Schensul, J. (2013). Sampling in ethnographic research. Initiating ethographic research: mixed a methods approach. Lanham, Maryland, Altamira Press. pp, 280-318.

Lachman, Beth E., John A. Ausink, William A. Williams, Katherine Pfrommer, Manuel J. Carrillo

2016. The Nevada Test and Training Range (NTTR) and Proposed Wilderness Areas Issues Affecting the NTTR's Land Withdrawal Renewal. Published by the RAND Corporation, Santa Monica, Calif.

Laczniak,R. J. LaRue Smith, and Guy A. DeMeo 
2000. Annual Ground-Water Discharge by

Evapotranspiration from Areas of Spring-Fed Riparian

Vegetation Along the Eastern Margin of Death Valley, 2000-02. U.S. GEOLOGICAL SURVEY Scientific

Investigations Report 2006-5145.

https://pubs.usgs.gov/sir/2006/5145/index.html.

Accessed 6/21/2018.

Ledbetter, J. D., Stevens, L. E., Springer, A. E., \& Brandt, B.

n.d. Springs Inventory Database. Documentation available at http://springstewardship. org/database. Html.

Lefler, Brian John

2014. Nuwuvi (Southern Paiute) Ecological Knowledge of Piñon-Juniper Woodlands: Implications for Conservation and Sustainable Resource Use in Two Southern Nevada Protected Areas Dissertations and Theses. Paper 2007. https://pdxscholar.library.pdx.edu/open_access_etds/2007

Lepofsky D, Lertzman K.

2008. Documenting ancient plant management in the northwest of North America. Botany. 86: 129-145.

Lempert, R. J., \& Groves, D. G.

2010. Identifying and evaluating robust adaptive policy responses to climate change for water management agencies in the American west. Technological Forecasting and Social Change, 77(6), 960-974.

Lertzman K.

2009. The Paradigm of Management, Management Systems, and Resource Stewardship. J Ethnobiol. 29: 339-358. 
https://scholar.google.com/scholar_lookup?journal=J+Ethnobiol\&title=T he+Paradigm+of+Management, +Management+Systems,+and+Resource+ Stewardship\&author $=K+$ Lertzman\&volume $=29$ \&publication_year $=2009$ \&pages $=339-358 \&$

Lewis, S. L., \& Maslin, M. A. 2015. Defining the anthropocene. Nature, 519(7542), 171-180.

\section{Linton, J.}

2010. What is water? The history of a modern abstraction. University of British Columbia Press, Vancouver

Loftin, J.D.

1991. Religion and Hopi life in the twentieth century. Indiana University Press, Bloomington, Ind.

Loftus A, Lumsden F.

2008. Reworking hegemony in the urban waterscape. Trans Inst Br Geogr 33:109-126

Lodge, Spencer

2016. Fire on the Mountain: Roasting Pits in the Sheep Range on Desert National Wildlife Refuge. M.A. Thesis.

Lundquist, J. D., \& Cayan, D. R. 2002. Seasonal and spatial patterns in diurnal cycles in streamflow in the western United States. Journal of Hydrometeorology, 3(5), 591-603.

MacDonald, G. M. 
2010. Water, climate change, and sustainability in the southwest.

Proceedings of the National Academy of Sciences, 107(50), 21256-21262.

Maffi, L., \& Woodley, E.

2010. Why is a biocultural approach relevant for sustaining life in nature and culture?. Biocultural diversity conservation: A global sourcebook, 1320.

Maxey, G. B., \& Eakin, T. E.

1949. Ground water in White River Valley, White Pine, Nye, and Lincoln Counties, Nevada.

McClenachan, L., Ferretti, F., \& Baum, J. K. 2012. From archives to conservation: why historical data are needed to set baselines for marine animals and ecosystems. Conservation Letters, 5(5), 349-359.

Miller, R. F., \& Wigand, P. E. (1994). Holocene changes in semiarid pinyon-juniper woodlands: response to climate, fire, and human activities in the US Great Basin. BioScience, 44(7), 465-474.

Merritt, D. M., \& Poff, N. L. R. 2010. Shifting dominance of riparian Populus and Tamarix along gradients of flow alteration in western North American rivers. Ecological Applications, 20(1), 135-152.

Moreo, M.T., Senay, G.B., Flint, A.L., Damar, N.A., Laczniak, R.J., and Hurja, James

2014. Hydroclimate of the Spring Mountains and Sheep

Range, Clark County, Nevada: U.S. Geological Survey 
Scientific Investigations Report 2014-5142, 38 p., https://pubs.usgs.gov/sir/2014/5142/pdf/sir2014-5142.pdf

Morris, L. R., \& Rowe, R. J.

2014. Historical land use and altered habitats in the Great Basin. Journal of Mammalogy, 95(6), 1144-1156.

Mrowka, R.

2014. Lawsuit Filed to Halt Massive Las Vegas Water Grab: Pipeline Would Dry Up Springs and Wetlands, Hurt Fish, Sage Grouse, Pronghorn and Other Species. Center for Biological Diversity, February, 12.

Nabhan, Gary Paul 2008. Plant Diversity Influenced by Indigenous management of Freshwater Springs Flora of Quitovac, Sonora, Mexico. In Stevens and Meretsky, Aridland springs in North America: ecology and conservation. University of Arizona Press, Tucson, AZ.

Nadasdy, Paul 1999. The politics of TEK: Power and the integration of knowledge. Arctic Anthropology, 1-18.

Naff, Richard, George Maxey, and Robert Kauffman

1974. Interbasin Groundwater Flow in Southern Nevada. Nevada Bureau of Mines and Geology Report 20.

Naumburg E, R. Mata-Gonzales, RG Hunter, T. McLendon, DW Martin 2005. Phreatophytic vegetation and groundwater fluctuations: a review of current research and application of ecosystem response modeling with an emphasis on Great Basin vegetation. 
Environmental Management 35:726-740.

Nevada Division of Water Resources

2014. Hydrographic Area Summary.

http://water.nv.gov/data/basinsummary/results.cfm. Accessed

Dec. 2016.

Nevada Department of Agriculture

n.d. Nevada Noxious Weed List.

http://agri.nv.gov/Plant/Noxious_Weeds/Noxious_Weed_List/.

Accessed Nov. 2016

Nevada Natural Heritage

2016. State of Nevada Wetland Program Plan.

http://heritage.nv.gov/node/310

Nevada State Historic Preservation Office

2017. Nevada Cultural Resources Information System (NVCRIS).

http://shpo.nv.gov/services/nvcris. Accessed November 2017.

Olsson, P., Folke, C., \& Hahn, T.

2004. Social-ecological transformation for ecosystem management: the development of adaptive co-management of a wetland landscape in southern Sweden. Ecology and society, 9(4).

Orlove, B., \& Caton, S. C.

2010. Water sustainability: Anthropological approaches and prospects. Annual Review of Anthropology, 39.

Oyarzun, Megan 
2016. Predicting Archaeological Site Locations in Northeastern California's High Desert using the Maxent Model. Dissertation, University Southern California.

Patten, D.T., L. Rouse, and J.C. Stromberg 2008. Isolated spring wetlands in the Great Basin and Mojave Deserts, U.S.A.: Potential response of vegetation to groundwater withdrawal. Environmental Management 41(3): 398-413.

Pavelko, Michael, David Wood, and Randell Laczniak. 1991. Las Vegas, Nevada: Gambling with water in the desert. https://pubs.usgs.gov/circ/circ1182/pdf/o8LasVegas.pdf

Pavelko, M. T., Wood, D. B., \& Laczniak, R. J. 1999. Las Vegas, Nevada. Land subsidence in the United States: US Geological Survey. Circular, 1182, 49-64.

Perla, B. S., \& Stevens, L. E. 2008. Biodiversity and productivity at an undisturbed spring in comparison with adjacent grazed riparian and upland habitats. Aridland springs in North America: Ecology and conservation, 230-243.

Plumwood, V. 1993. Dualism: The logic of colonisation. Feminism and the Mastery of Nature, 41-68.

Plumwood, V. 2005. Environmental culture: The ecological crisis of reason. Routledge. 
Ponder, W. F.

2002. Desert springs of the Australian Great Artesian Basin. In Proceedings of the meeting on Spring-fed wetlands: important scientific and cultural resources of the intermountain region (pp. 1-13).

Purcell, T.

1998. Indigenous knowledge and applied anthropology: Questions of definition and direction. Human organization, 57(3), 258-272

Rhode, David

2002. Native plants of southern Nevada. University of Utah Press.

Roberts, Heidi, Elizabeth Von Til Warren, and Suzanna Eskenazi. 2007. Coyote Named this Place Pakonapanti. Corn Creek National Register Archaeological District, Desert National Wildlife Refuge. Clark County, Nevada. HRA Report.

Roberts, Heidi and Richard V. Ahlstrom. 2012. A Prehistoric Context for Southern Nevada. HRA, Inc., Archaeological Report No. 011-05. 175

Robertson, H. A., \& McGee, T. K. 2003. Applying local knowledge: the contribution of oral history to wetland rehabilitation at Kanyapella Basin, Australia. Journal of environmental management, 69(3), 275-287.

Rosenberg, A. A., Bolster, W. J., Alexander, K. E., Leavenworth, W. B., Cooper, A. B., \& McKenzie, M.

2005. The history of ocean resources: modeling cod biomass using historical records. Frontiers in Ecology and the Environment, 3(2), 78-84. 
Sada, Don

2008. Great Basin Riparian and Aquatic Ecosystems. USDA Forest Service Gen. Tech. Rep. RMRS-GTR-204

http://www.fs.fed.us/rm/pubs/rmrs_gtr204/rmrs_gtr204_049_052

Sada, Donald W., and Alexandra D. Lutz

2016. Environmental Characteristics of Great Basin and Mojave Desert Spring Systems.

https://lccnetwork.org/sites/default/files/Resources/EnvironmentalChara cteristics_of_GreatBasin\%26MojaveDesert_SpringSystems_Final.pdf Accessed Jan 2017.

Sada, Don and Pohlmann

2002. Spring Inventory and Monitoring Protocols. Conference

Proceedings: Spring-fed Wetlands: Important Scientific and

Cultural Resources of the Intermountain Region.

https://www.dri.edu/images/stories/conferences_and_works

hops/spring-fed-wetlands/ spring-fed-wetlands-sada-

pohlmann-protocol.pdf

Sada, D.W. and G.L. Vinyard

2002. Anthropogenic changes in historical biogeography of Great Basin aquatic biota. Pages 277-293. In, R. Hershler, D.B. Madsen, and D. Currey (eds.). Great Basin Aquatic Systems History. Smithsonian Contributions to the Earth Sciences No. 33 .

Sada, D.W., J.E. Williams, J.C. Silvey, A. Halford, J. Ramakka, P. Summers, and L. Lewis 
2001. A guide to managing, restoring, and conserving springs in the western United States. Natural Areas Journal 87. Technical Reference 1737-17, United States Bureau of Land Management, National Science and Technology Center, [Denver, Colo.]. Volume 34 (1), 2014.

Sada, D.W., E. Fleischman, and D.D. Murphy 2005. Associations among spring dependent aquatic assemblages and environmental and land use gradients in a Mojave Desert mountain range. Diversity and Distributions 11:91-99.

Salmón, E. 2000. Kincentric ecology: indigenous perceptions of the humannature relationship. Ecological Applications, 10(5), 1327-1332.

Sapir, Edward

1930-31. The Southern Paiute Language. In, Proceedings of the American Academy of Arts and Sciences 65(1-3). Philadelphia.University of Colorado Law School Colorado Law Scholarly Commons. https://scholar.law.colorado.edu/. Accessed March 2018.

Seager, R., Ting, M., Held, I., Kushnir, Y., Lu, J., Vecchi, G., ... \& Li, C. 2007. Model projections of an imminent transition to a more arid climate in southwestern North America. Science, 316(5828), 1181-1184.

Shutler, R., \& Shutler, M. E. 1962. Archaeological Survey in Southern Nevada. Nevada State Museum. Onenevada.org 
Sinclair, David A., Springer, A.E., and Stevens, L.E. 2018. Geomorphological Influences on Physical and Biological Characteristics of Springs Ecosystems, Grand Canyon Ecoregion, Southwestern USA. Springs Ecosystem Science Symposium, Flagstaff, AZ.

Southern Nevada Water Association (SNWA) 2015a. Hydrological Studies, Groundwater Development Project. http://www.snwa.com/ws/future_gdp_hydro.html 2015b.Water Rights. http://www.snwa.com/ws/future_gdp_rights.h tml.

Spring Stewardship Institute n.d. Spring Types Index. http://springstewardshipinstitute.org/)Accesse d December 2017.

Spoon, Jeremy 2013. Different ways of knowing, shared goals: applied sustainability projects in the Nepalese Himalaya and Great Basin. Social Sustainability: A Multilevel Approach for Social Inclusion. Dujon, V., Dillard, J. F., \& Brennan, E. M., eds. New York: Routledge.

Spoon, Jeremy and Arnold, Richard 2012. Collaborative research and co-learning: integrating Nuwuvi (Southern Paiute) ecological knowledge and spirituality to revitalize a fragmented land. Journal for the Study of Religion, Nature \& Culture 6(4):477-500. 
Spoon, Jeremy, Arnold, Richard and the Nuwuvi Working Group 2011. Nuwu Kanee, Nuwu Tooveenup (Our Home, Our Story): Nuwuvi (Southern Paiute) and the Spring Mountains. Portland: Portland State University and The Mountain Institute.

2012a. Consultation Handbook: Nuwuvi (Southern Paiute), the Spring Mountains National Recreation Area and Desert National Wildlife Refuge Complex. Portland: Portland State University and The Mountain Institute.

2012b. Nuwu-Vots (our Footprints): Nuwuvi (Southern Paiute) and the Pahranagat Valley.

Portland: Portland State University and The Mountain Institute.

2012c. Our Gathering Place: Nuwu (Western Shoshone), Nuwuvi (Southern Paiute) and the Ash Meadows Landscape.

Portland: Portland State University and The Mountain Institute.

2013. Collaborative Resource Stewardship Plan:

Nuwuvi (Southern Paiute), the Spring Mountains

National Recreation Area and the Desert National

Wildlife Refuge Complex. Portland: Portland State

University and The Mountain Institute

Springer, Abe and Larry Stevens 2012. General Springs Restoration Plan Outline: Northern Arizona University Ecohydrology Class (GLG 670). 
https://static1.squarespace.com/static/551345b8e4bo5ad7b9

o7caef/t/5516odc8e4bo1b711312357b/1427508680024/SSI_

SpringsRestorationOutline.pdf

Springer, Abraham E., Lawrence E. Stevens, Diana E. Anderson, Roderic A.

Parnell, David K. Kreamer, L. A. Levin, and Stephen P. Flora.

2008. A comprehensive springs classification system. Aridland springs

in North America: ecology and conservation. University of Arizona

Press and Arizona-Sonora Desert Museum, Tucson AZ: 49-75.

Stein, Eric D. \& Shawna Dark \& Travis Longcore \& Robin Grossinger \& Nicholas Hall \& Michael Beland

2010. Historical Ecology as a Tool for Assessing Landscape Change and Informing Wetland Restoration Priorities. Wetlands 30:589-601.

Stephanson Anders

1996. Manifest destiny: American expansion and the empire of right. Hill and Wang.

Stevens, Lawrence 2008. Every Last Drop in Stevens and Meretsky eds. Aridland springs in North America: ecology and conservation. University of Arizona Press, Tucson, AZ.

Stevens LE, Meretsky VJ (eds)

2008. Aridland springs in North America: ecology and conservation. University of Arizona Press, Tucson, AZ.

Stevens, L. Robert J. Andress, Stephanie Carman, Joseph Gurrieri, David Kreamer, Donald R. Sada, and Cynthia Tait 
2012. A Restoration Guide for Nevada, Great Basin and Mojave/Sonoran Desert Springs: Executive Summary. http://docs.springstewardship.org/PDF/NevadaSpringsRestorationGuide. pdf

Steward, Julian 1938. Basin-Plateau Aboriginal Sociopolitical Groups. Washington: U.S. Government Printing Office. 1955 Theory of Culture Change: The Methodology of Multilinear Evolution. Urbana: University of Illinois Press.

Stewart, O. C. 1942. Culture Element Distributions: XVIII: Ute-Southern Paiute. Berkeley: University of California Press.

Stoffle, Richard W. and M. Nieves Zedeño

2001a. Historical Memory and Ethnographic Perspectives on the Southern Paiute Homeland. Journal of California and Great Basin Anthropology. 23(2): 227-246.

2001b. American Indian Worldviews I: The Concept "Power" and Its Connection to People, Places, and Resources. In American Indians and the Nevada Test Site. R.W.

Stoffle, M.N. Zedeño, and D.B. Halmo 2002. The Concept of 'Power' in Numic and Yuman Epistemology. High Plains Applied Anthropologist. 2(22): 172-193.

Swadley, W.C. and Carr, W.J. 
1987. Geologic map of the quaternary and Tertiary deposits of the Big Dune quadrangle, Nye County, Nevada, and Inyo County, California (No.

USGS/MAP/I--1767). Geological Survey, Denver, CO (United States).

https://www.osti.gov/biblio/60453. Accessed 2015.

Swetnam, T. W., Allen, C. D., \& Betancourt, J. L. S

1999. Applied historical ecology: using the past to manage for the future.

Ecological applications, 9(4), 1189-1206.

Thompson, R. S., \& Mead, J. I.

1982. Late Quaternary environments and biogeography in the Great Basin. Quaternary Research, 17(1), 39-55.

Unmack, P.J., and W.L. Minckley

2008. The demise of desert springs. Pp. 11-34 in L.E. Stevens

and V.J. Meretsky, eds., Aridland Springs in North America:

Ecology and Conservation. The University of Arizona Press

and Arizona-Sonora Desert Museum, Tucson.

U.S. Forest Service, State of Nevada Department of Conservation and

Natural Resources, and U.S. Fish and Wildlife Service.

1998. Conservation Agreement for the Spring Mountains

National Recreation Area. Clark and Nye Counties Nevada.

http://www.clarkcountynv.gov/airquality/dcp/Documents/L

ibrary/

other\%2oreports/collab/ConservationAgreementForTheSpringMountains

NRA_April_1998.pdf

U.S. Fish and Wildlife Service

2009. Comprehensive Conservation Plan Desert National Wildlife Refuge. 
https://www.fws.gov/uploadedFiles/CCP\%20Vol\%201.pdf )

2013. DNWR Spring and Water Development Management

Plan. Unpublished internal document.

\section{U.S. Geological Survey}

N.D. 212 S17 E59 34abbd2 Corn Creek Springs - N (Usgs-

$362621115212601)$

Site Data In The Water Quality Portal.

Https://Www.Waterqualitydata.Us/Provider/Nwis/Usgs-Nv/ Usgs$362621115212601 /$. Accessed August 2017.

Waters, C. N., Zalasiewicz, J., Summerhayes, C., Barnosky, A. D., Poirier, C., Gałuszka, A., ... \& Jeandel, C.

2016. The Anthropocene is functionally and stratigraphically distinct from the Holocene. Science, 351(6269), aad2622.

Weissinger, R. H., Perkins, D. W., \& Dinger, E. C.

2012. Biodiversity, water chemistry, physical characteristics, and anthropogenic disturbance gradients of sandstone springs on the Colorado Plateau. Western North American Naturalist, 72(3), 393-406.

Welden, F. W. 2003. History of Water Law in Nevada and the Western States. Research Division, Legislative Counsel Bureau.

West, P., Igoe, J., \& Brockington, D. 2006. Parks and peoples: the social impact of protected areas. Annu. Rev. Anthropol., 35, 251-277. 
Welsh, L. W., \& Endter-Wada, J. 2017. Piping water from rural counties to fuel growth in Las Vegas, Nevada: Water transfer risks in the arid USA West. Water Alternatives, 10(2), 420.

Wendel, Kendra

2012. Nuwuvi (Southern Paiute) ethnohydrology: Ecological and management knowledge of water and perceptions of restoration in two southern Great Basin protected areas. Master's thesis, Department of Anthropology. Portland State University.

Wendel, Kendra 2014. Lifeblood of the Earth: Nuwuvi (Southern Paiute) Hydrological Knowledge and Perceptions of Restoration in Two Southern Nevada Protected Areas.

White, Lynn

1967. The Historical Roots of Our Ecologic Crisis. Science 155.3767: 1203207. http://www.uvm.edu/ gflomenh/ENV-NGO-PA395/articles/LynnWhite.pdf

Winograd, I.J. and W. Thordarson 1975. Hydrogeologic and Hydrochemical Framework, South-Central Great Basin, Nevada-California, with Special Reference to the Nevada Test Site. U.S. Geological Survey Professional Paper 712-C, 126p.

Vellend, M., Baeten, L., Myers-Smith, I. H., Elmendorf, S. C., Beauséjour, R., Brown, C. D., ... \& Wipf, S. 
2013. Global meta-analysis reveals no net change in local-scale plant biodiversity over time. Proceedings of the National Academy of Sciences, 110(48), 19456-19459.

Veteto, J. R., \& Lockyer, J 2015. Applying anthropology to what? Tactical/ethical decisions in an age of global neoliberal imperialism. Journal of Political Ecology, 22(1), 357367.

Zedler, J. B., \& Kercher, S 2005. Wetland resources: status, trends, ecosystem services, and restorability. Annu. Rev. Environ. Resour., 30, 39-74. 


\section{APPENDICES}

\section{Appendix A. Consent to Participate in Research}

History, Ecology, Restoration, and Management of Springs in Desert National Wildlife Refuge, Nevada

October 2016

Greetings,

My name is Yarrow Geggus. I am requesting your participation in a research study on natural springs in Desert National Wildlife Refuge, Nevada. This research is being done in October 2016 as part of my Master's thesis in the Department of Anthropology at Portland State University in Portland, Oregon. I am gathering historical, biological, and cultural information about the springs from the deep past to the present, including human use, modification, and management. I am accomplishing this through interviews, archival research, and field ecology research. I invite you to participate in an interview because of your knowledge and experience related to the springs and their management.

If you agree to an interview, I will ask you what you know of the history, ecology, and management practices of the springs in the past and present. Interviews are expected to take approximately two hours. With your permission, interviews will be audio recorded and transcribed. Information you share in interviews will be included in a formal report deliverable to the U.S. Fish and Wildlife Service, as well as within my Master's thesis. These deliverables will be shared with all participants, the U.S. Fish and Wildlife Service, and Portland State University. Your identity will be kept confidential and will not be included in any published reports about this study.

Although this study carries minimal risk, participation in interviews may cause some inconvenience and possible loss of privacy and confidentiality. To address this, interviews will be scheduled at a mutually convenient time and data will be kept confidential within a password protected computer. Your personal identifiable information, such as your name or job title, will not be linked to published findings.

The benefits of participating in this study include contributing to a project that will enhance the current and historical record of Refuge springs and their change over time. Participants will receive a report that summarizes research findings and recommendations for future management. This report may be used 
by USFWS employee participants to guide future management decisions on the Refuge.

There is no financial compensation for participating. Your participation in this study is completely voluntary. You have the right to choose not to participate or to withdraw your participation at any point in this study.

If you have any questions, concerns or complaints at any time about the research study, please contact me by phone at: 971.207 .7736 , by email at:

geggus@pdx.edu, or my supervisor, Jeremy Spoon, at jspoon@pdx.edu.

If you have questions regarding your rights as a research participant, you may call the PSU Office for Research Integrity at (503) 725-2227 or 1(877) 4804400. The ORI is the office that supports the PSU Institutional Review Board (IRB). The IRB is a group of people from PSU and the community who provide independent oversight of safety and ethical issues related to research involving human participants. For more information, you may also access the IRB website at https://sites.google.com/a/pdx.edu/research/integrity.

\section{CONSENT}

You are making a decision whether to participate in this study. Your signature below indicates that you have read the information provided (or the information was read to you). By signing this consent form, you are not waiving any of your legal rights as a research participant.

You have had an opportunity to ask questions and all questions have been answered to your satisfaction. By signing this consent form, you agree to participate in this study. A copy of this consent form will be provided to you.

\begin{tabular}{|l|l|l|}
\hline & \\
\hline Name of Adult Subject(print) & Signature of Adult Subject & \\
\hline
\end{tabular}

INVESTIGATOR SIGNATURE

This research study has been explained to the participant and all of his/her questions have been answered. The participant understands the information described in this consent form and freely consents to participate.

Name of Investigator/ Research Team Member (type or print)

\begin{tabular}{|l|l|}
\hline & \\
\hline & \\
\hline \hline Signature of Investigator/ Research Team Member) & Date \\
\hline
\end{tabular}




\section{Appendix B. Semi-Structured Interview Questionnaire History, Ecology, Management, and Restoration of Natural Springs at Desert National Wildlife Refuge, Nevada}

Interviewee:

Date, Time, \& Location:

Structured Questions on Demographic Information and Affiliation with DNWR

1. What is your age?

2. What is your educational background?

3. What is your association with DNWR? (e.g. USFWS employee, work for partner agency)

4. What is your profession and your job title?

5. How long have you worked at this job/organization?

6. Please describe your role including job responsibilities, projects, experience etc. related to DNWR and springs in particular

\section{-Semi-Structured Questions-}

Knowledge of Refuge Springs

1. What has been your experience with springs in Desert National Wildlife Refuge? Please describe.

2. How many springs do you know about? What are they called?

1. Please locate them on the map (provided).

2. Which ones have you visited and when? How many times/ How often? What was the purpose of this visit(s)?

3. Do you have any experiences with these springs that you'd like to share?

4. To your knowledge, do other people visit the springs today? If so, whom?

5 . What types of activities do they conduct there?

Refuge Natural History and Anthropogenic Change- Please explain for all the springs in general as well as for any particular springs you know about.

3. What do you know about the natural history of springs on the Refuge? (including geological and ecological characteristics).

1. What plants and animals do you associate with springs on the Refuge? (Prompt with mammals, reptiles, amphibians, birds, etc.) Are these species: native or exotic or invasive? Rare or threatened? Widespread or endemic? 
2. Is the presence of certain plant or animal species a result of human activity?

4. How have humans interacted with, used, modified, and managed the springs across the following general time periods? (prompt with human habitation, land use, resource exploitation, conservation, agriculture, spiritual or religious association, etc.)

1. Early human occupation by Native Americans

2. After the arrival of European settlers

3. Recent history since Refuge creation in 1936

4. Present day, including contemporary use by Nuwuvi (if any), and by USFWS.

5. Do any of the springs have cultural significance (in the past or present)?

6. Are any of the springs associated with archaeological features or artifacts? If so, which springs, what features? Please be specific.

7. How are springs connected to each other and to the broader landscape?

8. What would you say are the main functions and importance of springs on the Refuge today?

Spring Condition

9. What indicators do you use to know that a spring is healthy or not? What characterizes an ideally healthy spring?

10. How would you describe the condition of the springs today, in general?

(e.g., good/poor threatened). Are they 'healthy'? In what condition are the individual springs you know about?

11. How has spring health changed over time?

12. Are springs facing any threats today? If so, what threats do they face? (if nothing, prompt about invasive species, drought, over drafting of groundwater, etc.)

1. What do you think needs to be done to address these threats?

13. How are springs directly or indirectly impacted by the following human activities, if at all?

1. Recreation

2. Regional population growth

3. Tourism

4. Climate change

14. What is your agency/organizaton's policy or response to these impacts? 
15. How do springs inside the Refuge compare to nearby springs outside the Refuge? Please explain in terms of how these have changed over time, past and present human use and management, and their current condition.

Spring Management

17. How are springs used and managed today?

1. What is the purpose of their use and management?

2. What is the basis of management decisions and planning?

18. Are the springs monitored?

1. If so, how, how often, and by whom? What qualities are measured? e.g. flow, water quality, surrounding vegetation, use by wildlife.

2. What is the purpose of this data/ how is it used?

3. If not monitored, do you think monitoring should occur? Why or why not? 19. What do you think are best practices in managing the springs on the Refuge in general?

20. Do individual Refuge springs have specific management needs?

21. In your opinion, how could current spring management be improved?

22. Have restoration techniques been applied to springs on the Refuge? Please explain.

23. What is the role of local/ traditional Nuwuvi or Southern Paiute knowledge in the management of natural springs? What benefits and challenges are involved? 


\section{Appendix C. Vascular Plant Species Identified During Survey (listed alphabetically)}

\section{Native Species}

1. Agave, Agave utahensis

2. Alkali sacaton, Sporobolus airoides

3. Anderson's wolfberry, Lycium andersonii

4. Apache plume, Fallugia paradoxa

5. Basin wild rye, Leymus cinereus

6. Beardless wildrye, Leymus triticoides

7. Blackbrush, Coleogyne ramosissima

8. Buckwheat, Erigonum spp.

9. Cattail, Typha spp.

10. Cholla, Cylindropuntia spp.

11. Common Reed, Phragmites australis

12. Cocklebur, Xanthium strumarium

13. Cottonwood, Populus sp. angustifolia?

14. Crimson columbine, Aquilegia Formosa

15. Desert almond, Prunus fasciculata

16. Desert bitterbush, Purshia glandulosa

17. Desert needlegrass, Achnatherum speciosum

18. Desert snowberry, Symphoricarpos longiflorus

19. Evening primrose, Oenothera spp.

20. Fremont's mahonia, Mahonia fremontii

21. Fourwing saltbush, Atriplex canescens

22. Gooseberry, Ribes spp.

23. Indian ricegrass, Achnatherum hymenoides

24. Mallow, Sphaeralcea spp.

25. Mojave thistle, Cirisium mohavense

26. Mojave woodyaster, Xylorhiza tortifolia

27. Mojave yucca, Yucca schidigera

28. Mormon tea, Ephedra viridis

29. Mountain sagewort, Artemisia ludoviciana

30. Nevada jointfir, Ephedra nevadensis

31. Nuttall's linanthus, Leptosiphon nuttallii

32. Opuntia, Opuntia spp.

33. Pigweed, Chenopodium incanum

34. Pinyon pine, Pinon monophylla

35. Ponderosa pine, Pinus ponderosa

36. Rabbit brush, Ericameria spp.

37. Rocky mountain juniper, Juniperus scropulorum

38. Rush, Juncus spp. 
39. Rye grass, Leymus spp.

40.Sage Salvia spp. dorrii

41. Saltbush, Atriplex spp.

42. Shadescale, Atriplex confertifolia

43. Sand verbena, Abronia turbinate

44. Service berry, Amelanchier utahensis

45. Skunkbush sumac, Rhus trilobata

46. Snakeweed, Gutierrezia spp.

47. Utah juniper, Juniperus osteosperma

48. Western tansy mustard, Descurainia pinnata

49. Goodding's willow, Salix gooddingii

50. Woods rose, Rosa woodsi

\section{Introduced Species}

1. Cheatgrass, Bromus tectorum

2. Common mullein, Verbascum thapsus

3. Dandelion, Taraxcum officinale

4. Horehound, Marrubium vulgare

5. Kentucky bluegrass, Poa pratensis

6. Rabbitsfoot grass, Polypogon monspeliensis

7. Red brome, Bromus rubens

8. Sweet clover Melilotus officinalis 
Image 13. Native wiregrass, Juncus sp., along with introduced mullein, thriving around the troughs thanks to its overflow.

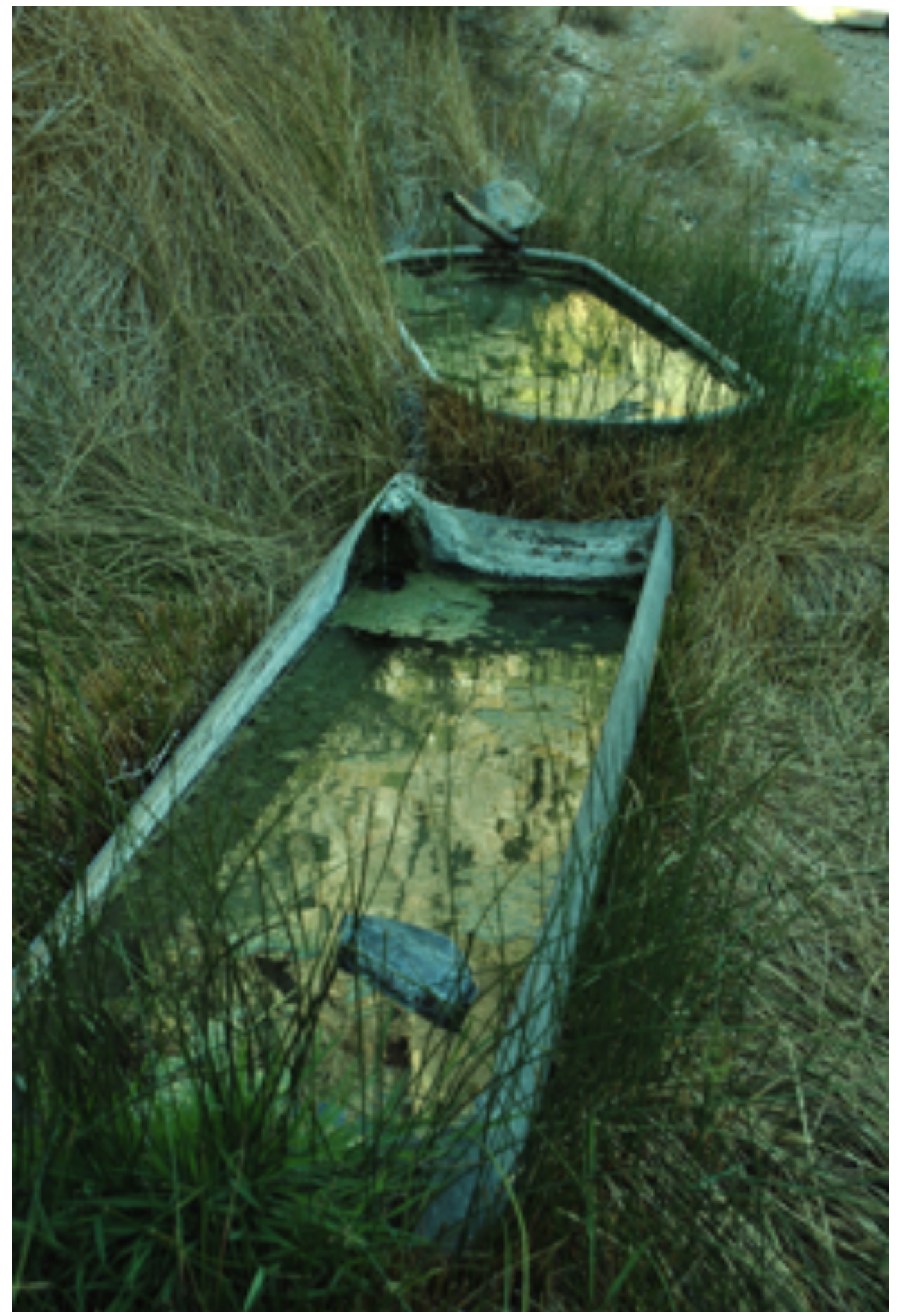




\section{Appendix D. Introduced Vascular Plant Species of DNWR Springs}

Cheatgrass (Bromus tectorum) was the most widespread non-native species, present at nine springs $(\mathrm{n}=9$ of 10$)$; this was followed by red brome (recorded at two springs) and horehound ( $\mathrm{n}=2$ of 10). In addition to those eight species I encountered in field surveys, a further eight non-native species are known from springs on the Refuge. Salt cedar (Tamarix sp.), a noxious weed historically present on the Refuge and removed from Spring 5, Upper White Blotch, Lower White Blotch, and Spring 3s in the last twenty years, was not detected at any springs in this study. Non-native species comprised an average of $26 \%$ of the species richness at springs (min. $7 \%$ at Spring 6, max 66\% at Spring 5). The number of non-native to-native species follows a weak, positive correlation (Pearson correlation coefficient $=0.23, \mathrm{p}<0.05$ ) indicating that higher overall species richness is somewhat correlated to higher number of non-native species.

There was no significant relationship between the proportion of nonnative species to native species and their frequency of occurrence in survey plots (abundance). The number of non-native species was positively correlated to their abundance $(\mathrm{p}<0.05)$. Overall species richness and abundance of non-native species follow a weak, negative correlation (Pearson correlation coefficient=-0.14, p $>0.05$ ), indicating that more heavily invaded sites may be associated with less plant species overall but this was not significant for the sample. The most invaded site in terms of frequency of occurrence of introduced species in study 
plots was Spring 5 ( 9 of 9 plots), followed by Spring 4 ( 8 of 9 plots) and Spring 2 (6 of 9 plots). Records indicate that invasive species, such as horehound, have been present at Spring 5 at least since the 1980s. Spring 6 source had the least occurrence of non-native plants, with a single non-native species (Dandelion, Taraxcum spp.) detected in one plot. Spring 6 is the only spring in this study where cheatgrass was not detected. A previous study (Abella et al. 2014) noted that invasive species were not present at five higher elevation springs above 7,oooft, with the exception of dandelion at Spring 6. Non-native annual grasses, such as rabbits'-foot grass (Polypogon monspeliensis), known to occupy moist sites, displayed more frequency near the springhead, whereas cheatgrass (Bromus tectorum), which occur across a broad moisture gradient, did not have a relationship with distance to water (Abella et al. 2014).

The linear regressions below show that elevation and species richness do not exhibit a linear relationship, and are therefore not correlated to trends in overall species richness or introduced species richness. Elevation and overall plant species richness (native and non-native combined) did not have a significant linear relationship (Figure 10), nor did elevation and non-native plant species (Figure 11). Further, species richness was not significantly correlated to disturbance rating (see section on spring ecological disturbance below). Differences in plant composition of springs at similar elevation are influenced by a number of other factors including aspect, slope, soil moisture and soil type, 
and the frequency and intensity of natural and anthropogenic sources of disturbance.

Figure 1o. Scatterplot with trend line plots the relationship between number of plant taxa and elevation. Pearson's correlation $\left(r^{2}=0.06, p>0.93\right)$ indicates that elevation and overall plant species richness are not correlated.

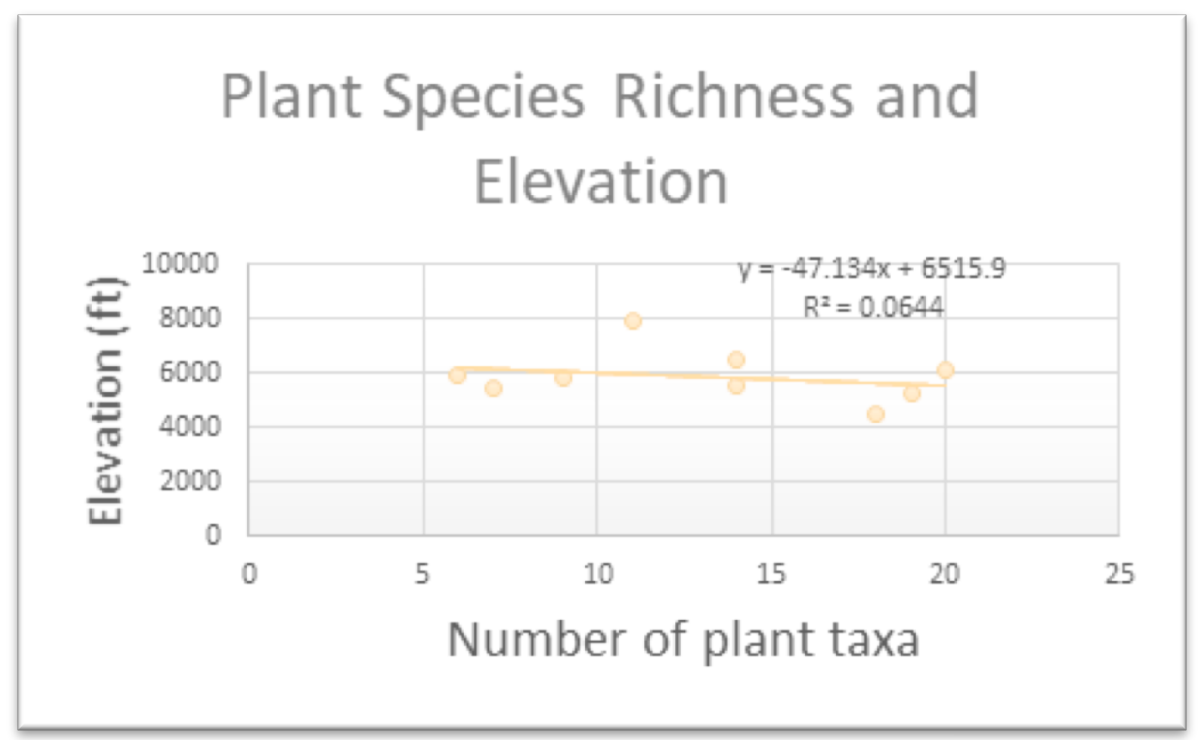

Figure 11. Scatterplot with trend line plots the relationship between number of nonnative plant taxa and elevation. Pearson's correlation $(r 2=0.13, p>0.29)$ indicates that elevation is not significantly correlated to non-native plant species richness.

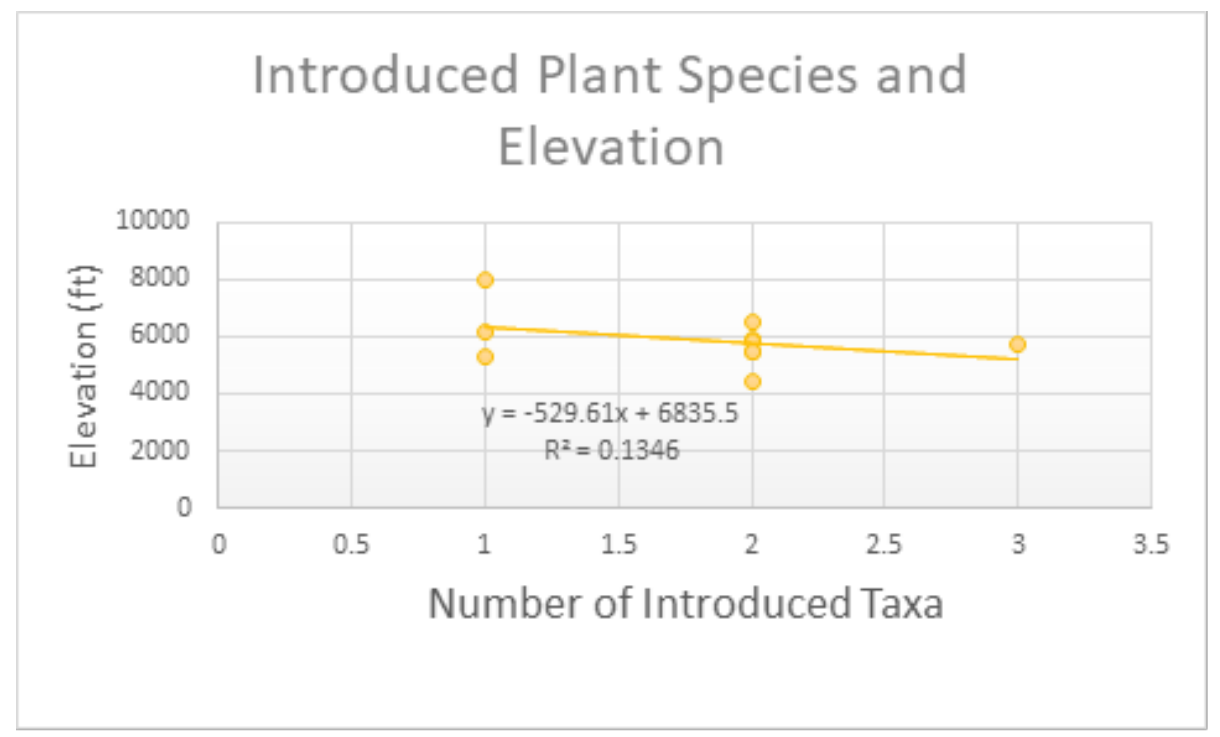




\section{Minimal Invasion of Introduced Species}

The impact of non-native species at springs is not severe given the absence of noxious non-native species (Nevada Department of Agriculture, n.d). This is a positive finding for native ecosystem integrity and spring health. Non-native and invasive species can be detrimental to springs by competing with native flora, altering water availability and fire regimes, and eliminating habitat for native species (Abele 2011). Ironically, the diversion of spring water from the surface may make these sites less prone to invasion by a number of invasive species that target resource-rich sites (Abella et al. 2014). This relatively low infestation by non-native species applies to the Refuge vegetation more broadly, likely thanks to the area's isolation and relative dearth of exploitable water and resources. In the case of the nearby Spring Mountains, where there are also relatively low levels of invasion, Fleishman et al. (2006 p.1099) suggest that rapid restoration and management actions may prevent introduced species from substantially modifying the natural ecological processes, patterns of distribution and abundance of the range's native biological diversity. Understanding patterns in native and non-native vegetation assemblages supports the effective and practical management of springs and habitat on USFWS lands (Fleishman et al. 2006). Due to the small sample size of springs $(n=10)$ these analyses contribute preliminary data to trends that may exist in floristic composition of springs on the Refuge. 
Table D. List of introduced plant species recorded at Refuge springs across three studies

\begin{tabular}{|c|c|c|c|c|c|c|c|}
\hline Species & $\begin{array}{l}\text { Common } \\
\text { name }\end{array}$ & Family & Spring & $\begin{array}{l}\text { Geggus } \\
2016\end{array}$ & $\begin{array}{l}\text { Ackerman } \\
2003\end{array}$ & $\begin{array}{l}\text { Abella } \\
\text { et al. } \\
\mathbf{2 0 1 4}\end{array}$ & Notes \\
\hline $\begin{array}{l}\text { Bromus } \\
\text { rubens }\end{array}$ & Red Brome & Poaceae & \begin{tabular}{|l|} 
Spring \\
$2 ;$ \\
Spring \\
$3 ;$ \\
Spring \\
$7 ;$ \\
Spring8; \\
three \\
other \\
springs
\end{tabular} & $\mathrm{X}$ & $\mathrm{X}$ & $\mathrm{X}$ & $\begin{array}{l}\text { Introduced annual. Widespread, esp. on disturbed } \\
\text { areas. [Ackerman 2003] SHR. Spring 2, Spring 3, } \\
\text { LVR Spring 7, Spring 8, and three other } \\
\text { springs.1160-2015m, 3800-66ooft.(Abella et al. } \\
\text { 2014) }\end{array}$ \\
\hline $\begin{array}{l}\text { Bromus } \\
\text { tectorum }\end{array}$ & Cheatgrass & Poaceae & $\begin{array}{l}\text { Spring } \\
3 ; \\
\text { Spring } \\
2\end{array}$ & $\mathrm{X}$ & $\mathrm{X}$ & $\mathrm{X}$ & $\begin{array}{l}\text { Introduced annual. Common in washes, disturbed } \\
\text { area, and at springs with mixed shrubs, blackbrush, } \\
\text { and sagebrush-blackbrush. PTR Quartz and Tim } \\
\text { Spring. SHR Spring } 3 \text { 1310-1950m, 4300-6400ft. } \\
\text { Spring 2, and one other spring Abellaet al. } 2014\end{array}$ \\
\hline $\begin{array}{l}\text { Erodium } \\
\text { cicutarium }\end{array}$ & $\begin{array}{l}\text { Redstem Filaree/ } \\
\text { Redstem Storks } \\
\text { Bill }\end{array}$ & Geraniaceae & $\begin{array}{l}\text { Spring } \\
6 \text { and } \\
\text { one } \\
\text { other } \\
\text { spring }\end{array}$ & & & $\mathrm{X}$ & $\begin{array}{l}\text { Introduced annual. LVR one spring, SHR Spring 6s } \\
\text { (Abella et al. 2014) }\end{array}$ \\
\hline $\begin{array}{l}\text { Frangula } \\
\text { californica }\end{array}$ & Coffeeberry & Rhamnaceae & $\begin{array}{l}\text { One } \\
\text { SHR } \\
\text { spring }\end{array}$ & & & & $\begin{array}{l}\text { From Spring files } \\
\text { Note : Charlet et al. } 2013 \text { identify as } \\
\text { Frangula betulifolia, a native species }\end{array}$ \\
\hline $\begin{array}{l}\text { Marrubium } \\
\text { vulgare }\end{array}$ & Horehound & Lamiaceae & $\begin{array}{l}\text { Spring } \\
5 ; \\
\text { Spring } \\
9\end{array}$ & $\mathrm{X}$ & $\mathrm{X}$ & & $\begin{array}{l}\text { Introduced perennial. Local in washes, near springs } \\
\text { and disturbed areas with alkali goldenbush, and } \\
\text { sagebrush-PJ. LVR and SHR. 915-1950m, 3000- } \\
\text { 640oft [Ackerman 2003] }\end{array}$ \\
\hline $\begin{array}{l}\text { Melilotus } \\
\text { officionalis alba }\end{array}$ & $\begin{array}{l}\text { Sweet White } \\
\text { Clover }\end{array}$ & Fabaceae & $\begin{array}{l}\text { Spring } \\
4\end{array}$ & $\mathrm{X}$ & $\mathrm{X}$ & & $\begin{array}{l}\text { Introduced annual. Disturbed areas. SHR Spring } 4 \\
\text { 1710m, 56ooft. [Ackerman 2003] }\end{array}$ \\
\hline
\end{tabular}




\begin{tabular}{|c|c|c|c|c|c|c|c|}
\hline Species & $\begin{array}{l}\text { Common } \\
\text { name }\end{array}$ & Family & Spring & $\begin{array}{l}\text { Geggus } \\
2016\end{array}$ & $\begin{array}{l}\text { Ackerman } \\
2003\end{array}$ & $\begin{array}{l}\text { Abella } \\
\text { et al., } \\
\mathbf{2 0 1 4}\end{array}$ & Notes \\
\hline $\begin{array}{l}\text { Mentha spicata } \\
\text { var. spicata }\end{array}$ & Spearmint & Lamiaceae & $\begin{array}{l}\text { Not } \\
\text { specified }\end{array}$ & & $\mathrm{X}$ & & $\begin{array}{l}\text { Introduced perennial. Disturbed areas near } \\
\text { springs. CCFS 885m, 26ooft. [Ackerman } \\
\text { 2003] }\end{array}$ \\
\hline Poa pratensis & $\begin{array}{l}\text { Kentucky } \\
\text { Bluegrass }\end{array}$ & Poaceae & Spring 6 & & $\mathrm{X}$ & $\mathrm{X}$ & $\begin{array}{l}\text { Introduced perennial grass. Local with } \\
\text { ponderosa. Wet Areas. SHR Spring 6s. 2375m } \\
\text { 780oft. [Ackerman 2003] and (Abella et al. } \\
\text { 2014) }\end{array}$ \\
\hline $\begin{array}{l}\text { Polypogon } \\
\text { monspeliensis }\end{array}$ & $\begin{array}{l}\text { Rabbit's-foot } \\
\text { grass }\end{array}$ & Poaceace & $\begin{array}{l}\text { Spring 7; } \\
\text { Spring } \\
9 ; \\
\text { Spring 2; } \\
\text { Spring 3 }\end{array}$ & & $\mathrm{X}$ & $\mathrm{X}$ & $\begin{array}{l}\text { Introduced annual. Local in wet areas of } \\
\text { springs. LVR Spring } 7 \text { and seep area of Spring } \\
\text { 9. PTR one spring. SHR Spring 2. 885- } \\
\text { 1980m, 2900-650oft. [Ackerman 2003] SHR } \\
\text { Spring 2, Spring 3, Spring } 7 \text { (Abella et al. } \\
\text { 2014) }\end{array}$ \\
\hline $\begin{array}{l}\text { Polypogon viridis } \\
\text { aka } \\
\text { Agrostis viridis }\end{array}$ & Water Bentgrass & Poaceae & $\begin{array}{l}\text { Spring } \\
5 ; \\
\text { Spring } \\
1 ; \\
\text { Spring } 4 \\
\end{array}$ & & $\mathrm{x}$ & & $\begin{array}{l}\text { Introduced perennial grass. Wet areas. } \\
\text { Springs 885-1800m, 2900-5900ft. SHR }\end{array}$ \\
\hline $\begin{array}{l}\text { Tamarix } \\
\text { ramosissima }\end{array}$ & Saltcedar & Tamaricaceae & $\begin{array}{l}\text { Spring 7; } \\
\text { two LVR } \\
\text { springs }\end{array}$ & & $\mathrm{x}$ & $\mathrm{X}$ & $\begin{array}{l}\text { Introduced shrub or small tree. LVR Lower } \\
\text { and Upper Blotch springs 885-1370m, 2900- } \\
\text { 450oft. [Ackerman 2003] LVR Spring } 7 \\
\text { (Abella et al. 2014) }\end{array}$ \\
\hline $\begin{array}{l}\text { Taraxacum } \\
\text { officinale. }\end{array}$ & \begin{tabular}{|l|} 
Common \\
Dandilion
\end{tabular} & Asteraceae & $\begin{array}{l}\text { Spring } \\
6\end{array}$ & $\mathrm{X}$ & & $\mathrm{X}$ & Perennial, (Abella et al. 2014) \\
\hline $\begin{array}{l}\text { Verbascum } \\
\text { thapsus }\end{array}$ & $\begin{array}{l}\text { Common } \\
\text { Mullein }\end{array}$ & Scrophulariaceae & Spring 1 & $\mathrm{x}$ & $\mathrm{x}$ & & $\begin{array}{l}\text { Introduced biennial herb. Local in spring } \\
\text { runoff. SHR Spring } 1 \text { 1800m 5900ft. } \\
\text { [Ackerman 2003] }\end{array}$ \\
\hline
\end{tabular}


Appendix E. Sample Spring Profile: Spring 9, Las Vegas Range

\begin{tabular}{|l|l|}
\hline $\begin{array}{l}\text { Spring } \\
\text { Name }\end{array}$ & Spring 9 \\
\hline Range & Las Vegas Range \\
\hline Elevation & 6,48ft \\
\hline $\begin{array}{l}\text { Vegetation } \\
\text { type }\end{array}$ & Pinon-Juniper Woodland (Pygmy Conifer) \\
\hline Location & $\begin{array}{l}\text { Coordinates published in the Deliverable to USFWS (Geggus and } \\
\text { Spoon 2018) }\end{array}$ \\
\hline Access & $\begin{array}{l}\text { Published in the Deliverable to USFWS (Geggus and Spoon } \\
\text { 2018) }\end{array}$ \\
\hline
\end{tabular}

\section{Appendix E. Spring Profile Spring 9, Las Vegas Range, continued}

Image 14. Spring 9 box, October 2016. Spring is cut into the side of a cliff and periodically fills with soil and rocks

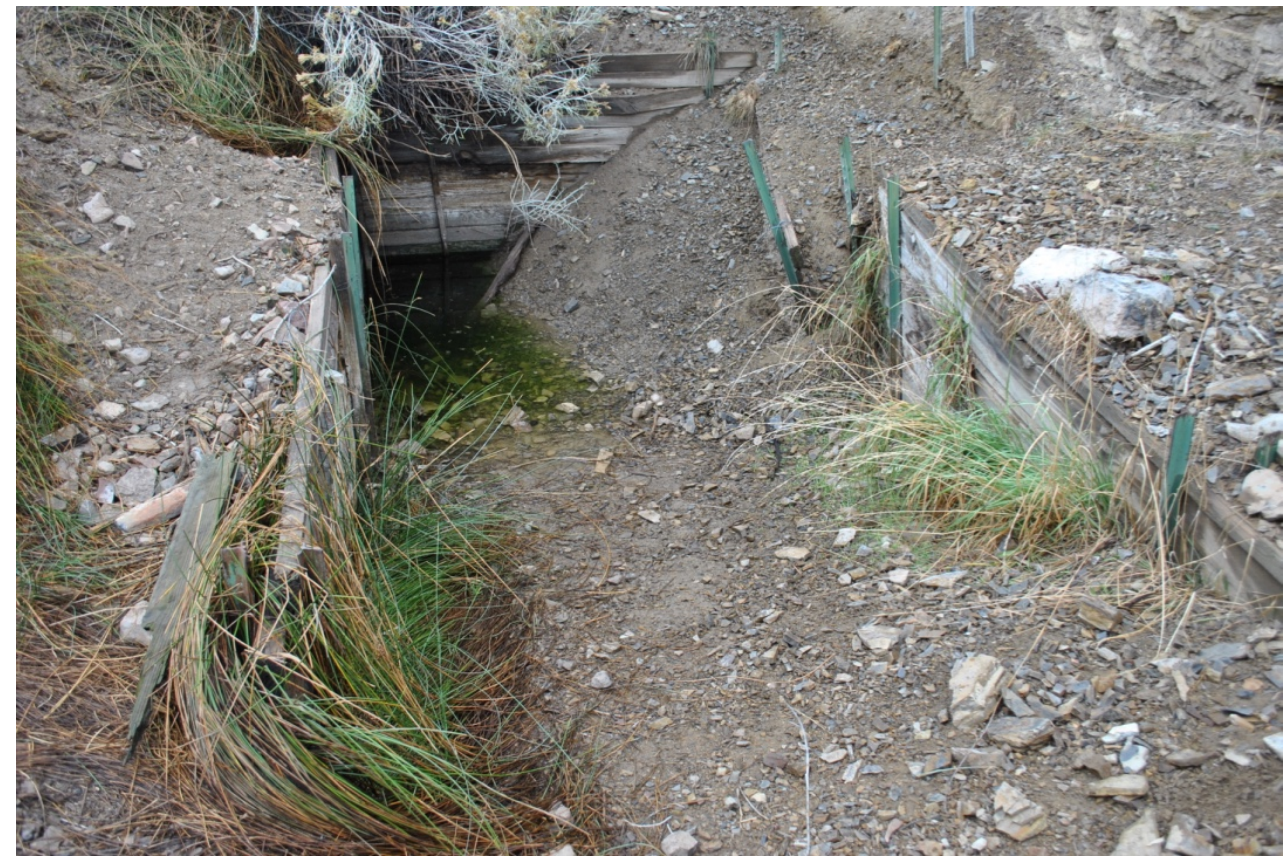


Image 15. Spring 9 pictured more full of water on June 2009, photo by USFWS

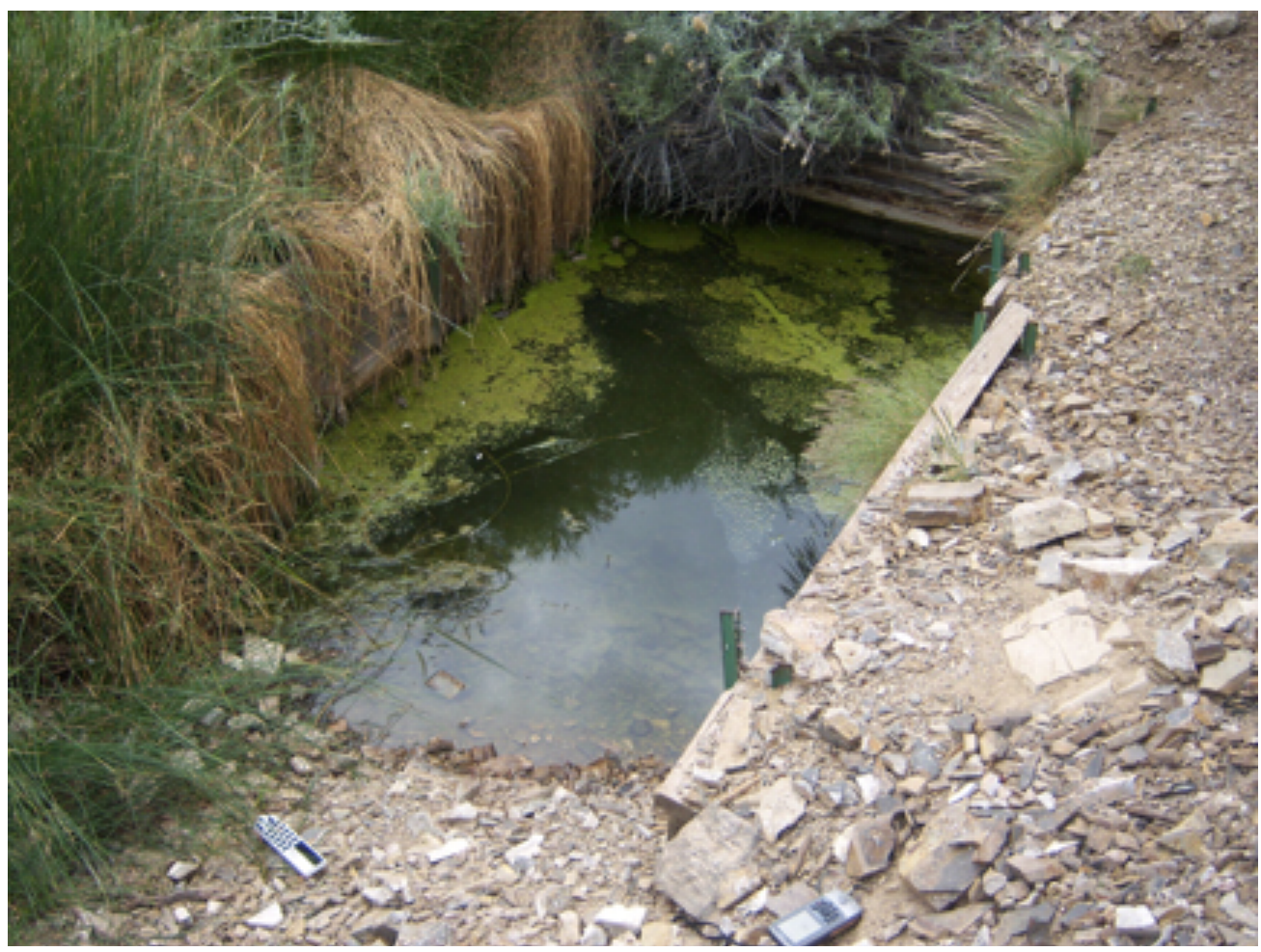

Appendix E. Spring Profile Spring 9, Las Vegas Range, continued

\begin{tabular}{|l|l|}
\hline Spring Type & Hypocrene \\
\hline Surrent development & Modified spring head: Wooden spring box \\
partially buried at base of cliff, made of fence \\
posts with boards behind them. \\
Unclear if historic diversions still in ground, \\
trough/drinkers dry.
\end{tabular}




\begin{tabular}{|l|l|}
\hline $\begin{array}{l}\text { Flow rate/presence of } \\
\text { water }\end{array}$ & Water 9.5 inches deep in corner of the box only \\
\hline Management needs & $\begin{array}{l}\text { Clear out rocks/debris from box and } \\
\text { reinforce/rebuild box; box needs to be cleaned } \\
\text { out and shored up yearly. }\end{array}$ \\
\hline $\begin{array}{l}\text { Introduced/Invasive } \\
\text { species noted }\end{array}$ & $\begin{array}{l}\text { Cheatgrass (Bromus tectorum) } \\
\text { Horehound (Marrubium vulgare) }\end{array}$ \\
\hline
\end{tabular}

\section{Appendix E. Spring Profile Spring 9, Las Vegas Range, continued}

Image 16. Former cattle troughs where spring water was piped and impounded from Spring 9. Photo by USFWS

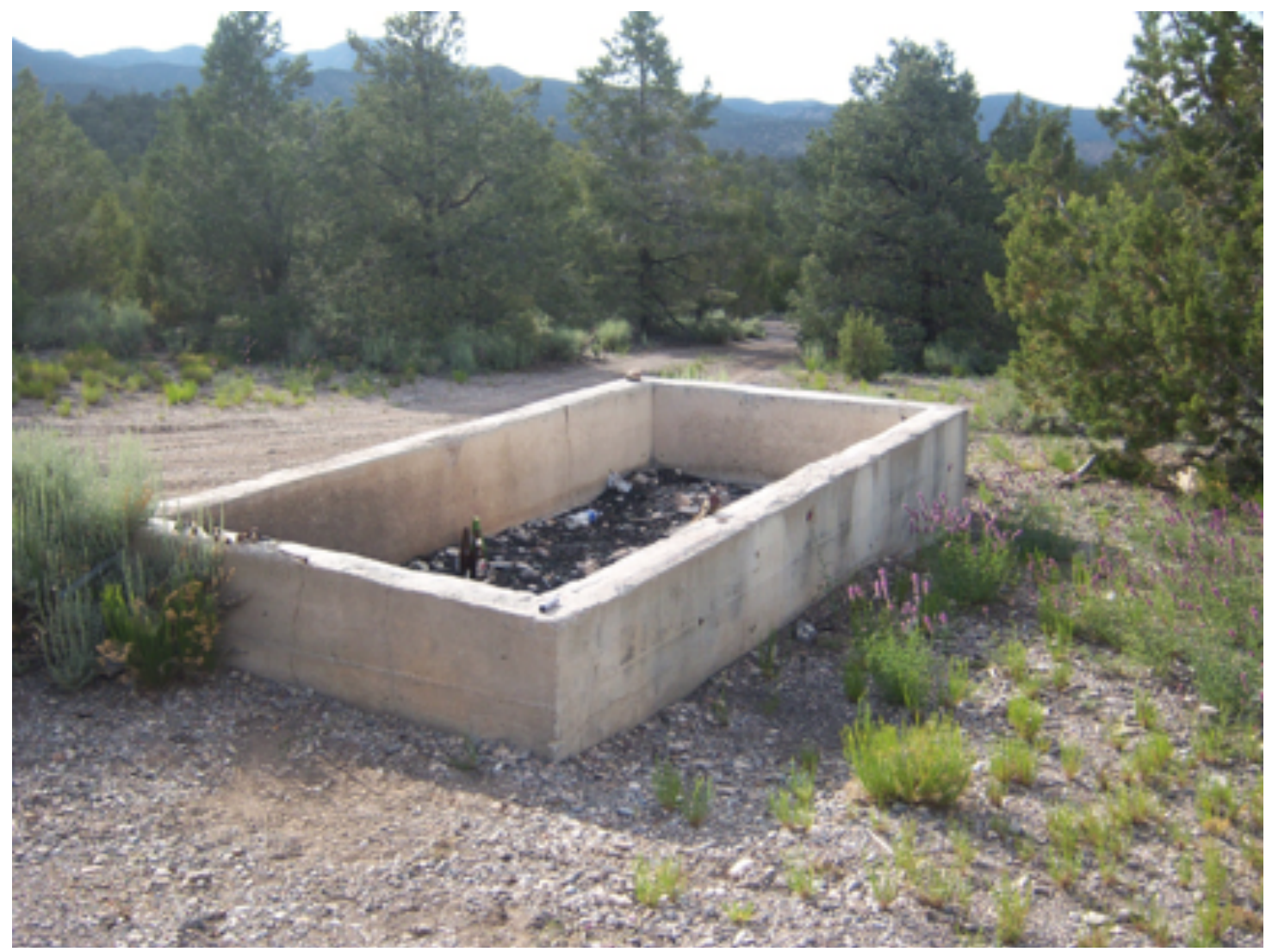


Image 17. Remnants of a roasting pit near Spring 9. Photo by USFWS

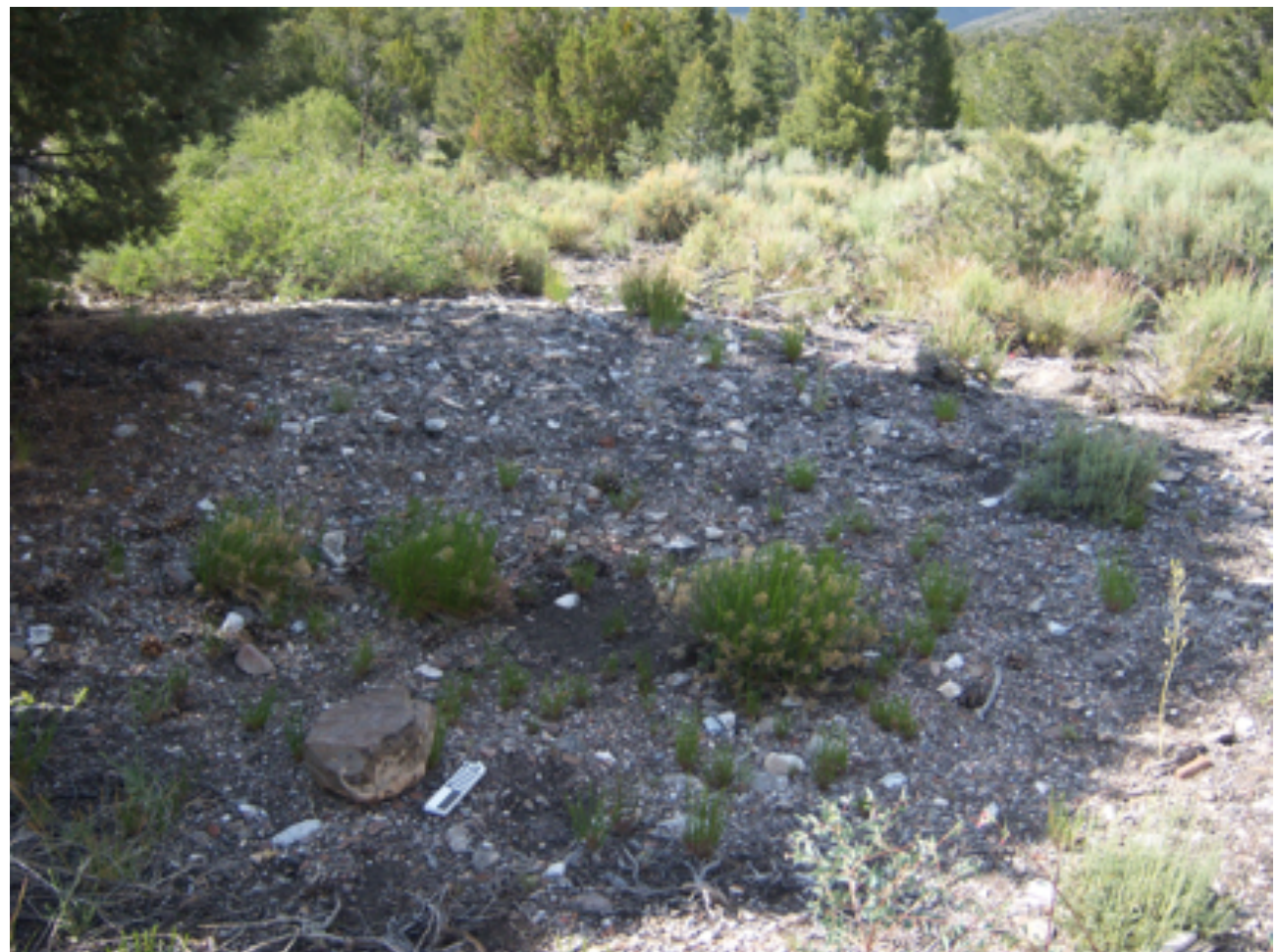

Image 18. Historical tin scan debris scatter, Spring 9. Photo by USFWS

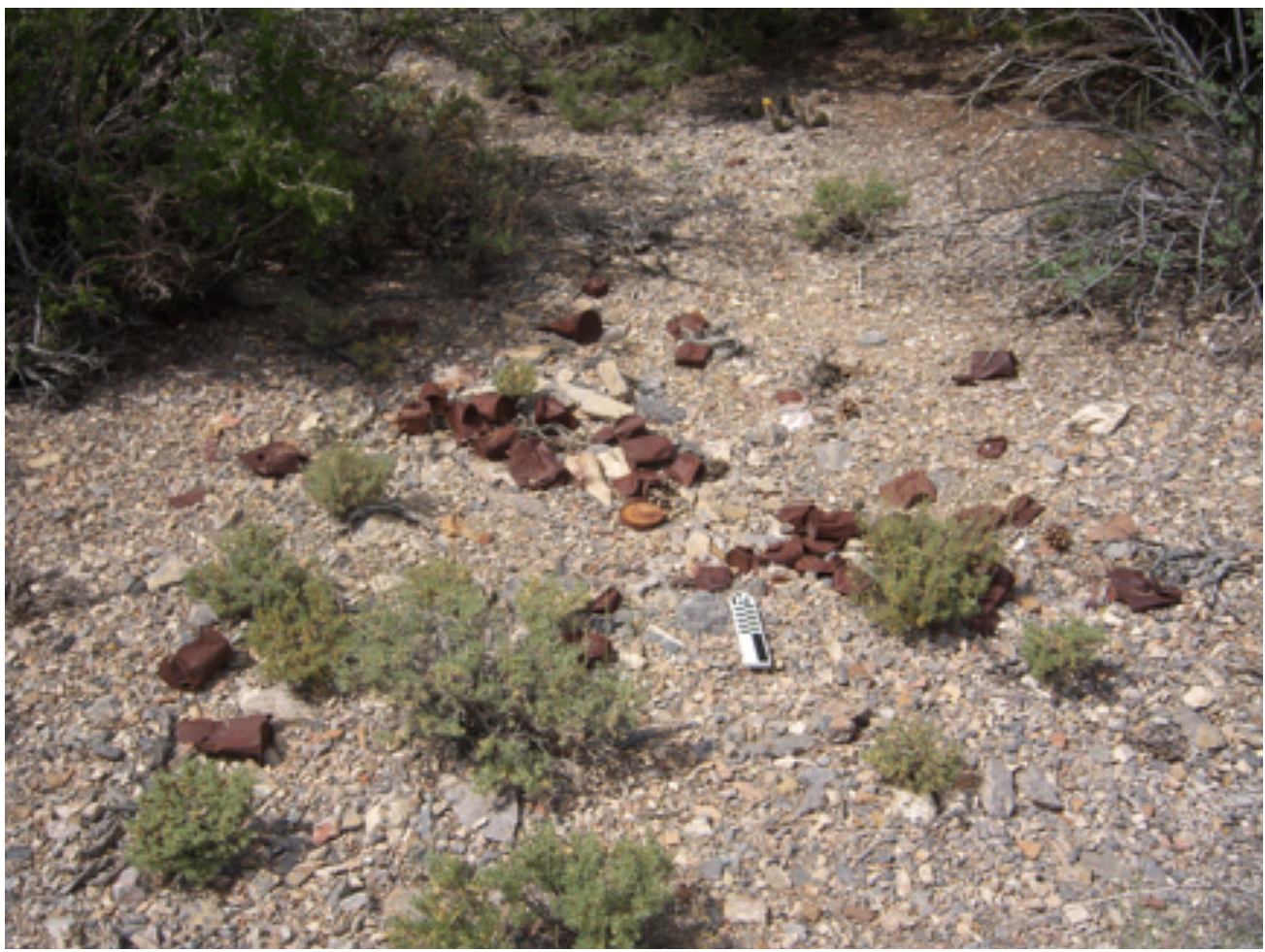


Image 19. A prehistoric biface tool recorded near Spring 9

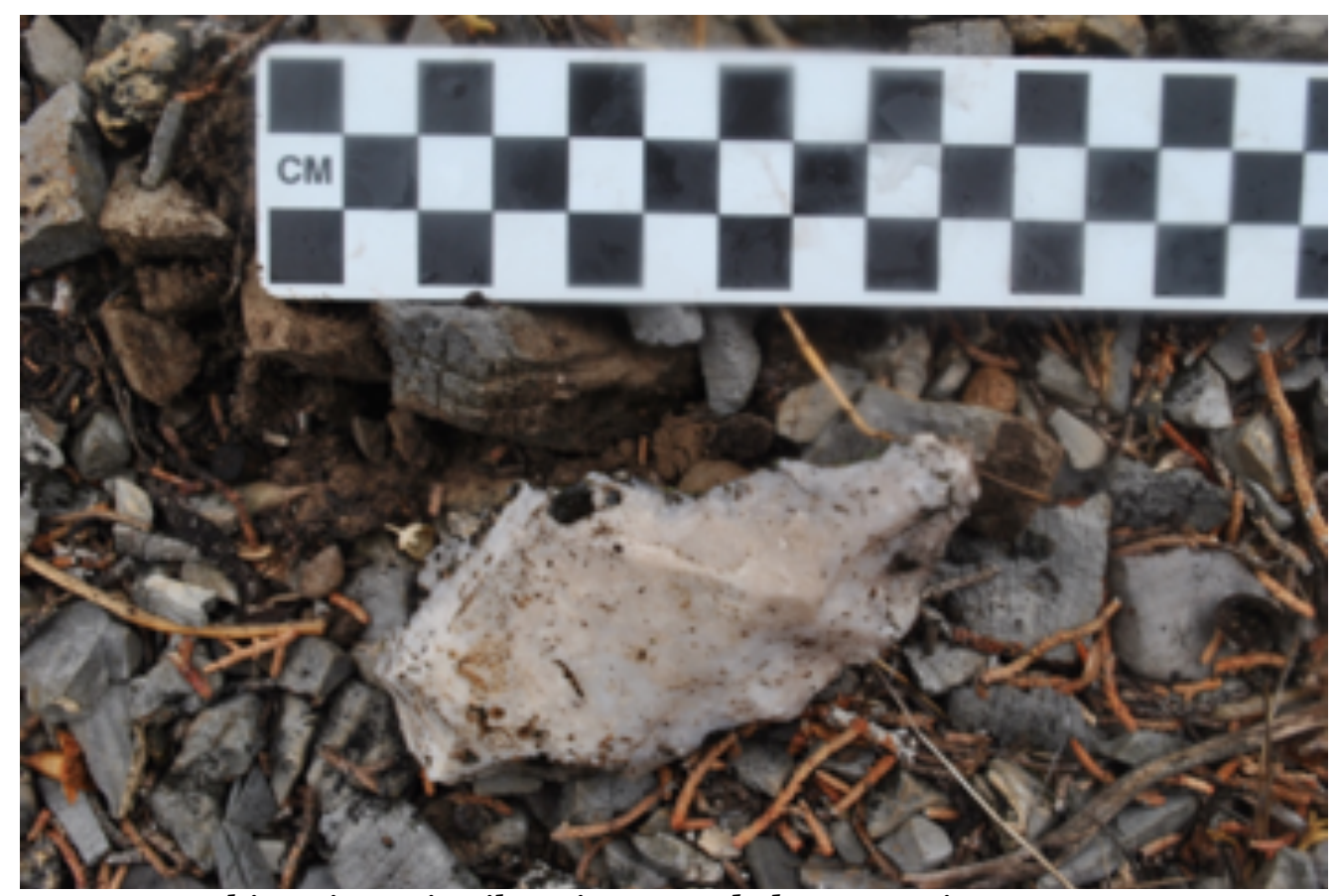

Image 2o. A prehistoric projectile point recorded near Spring 9

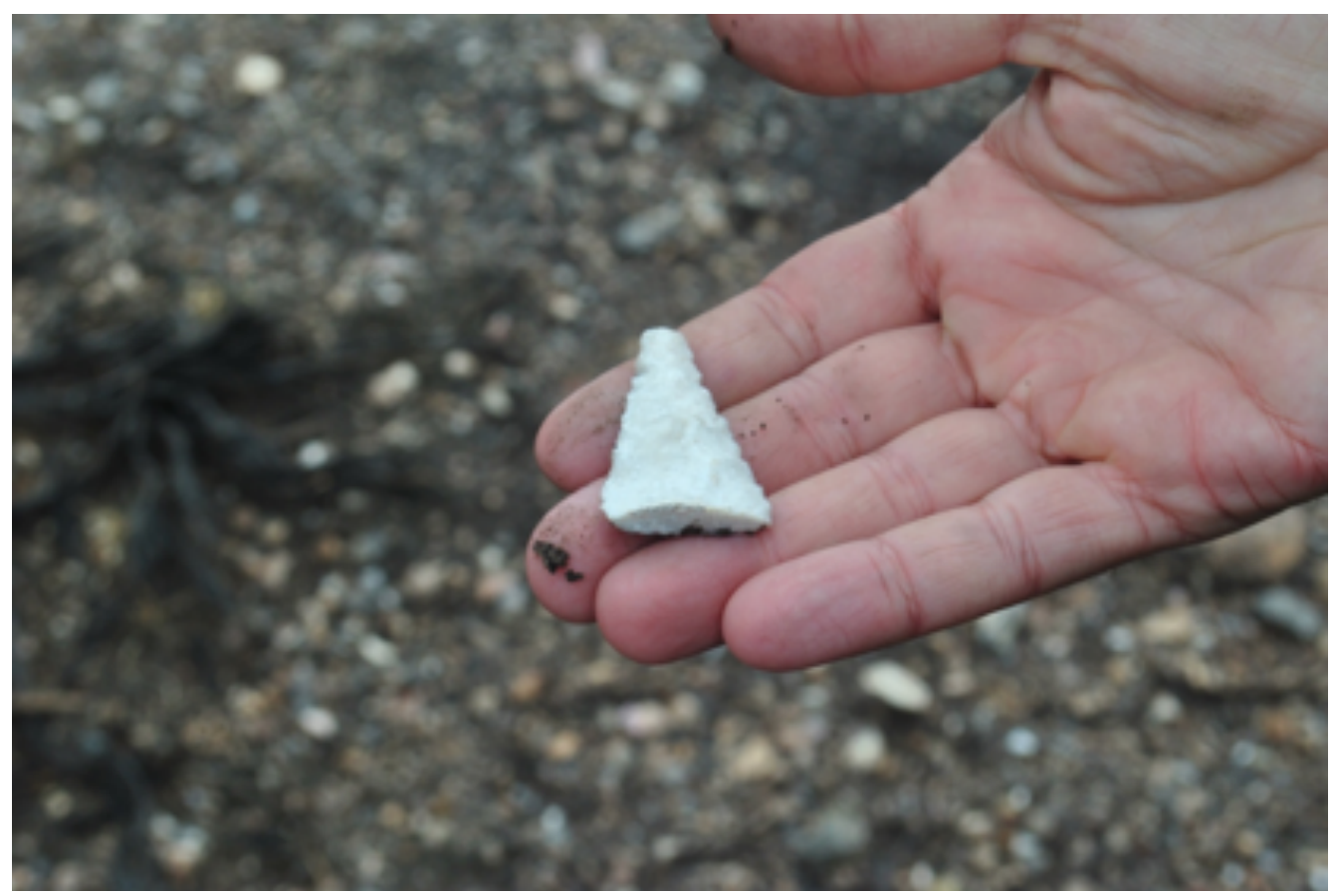


Image 21. Historical juniper post corral near Spring 9

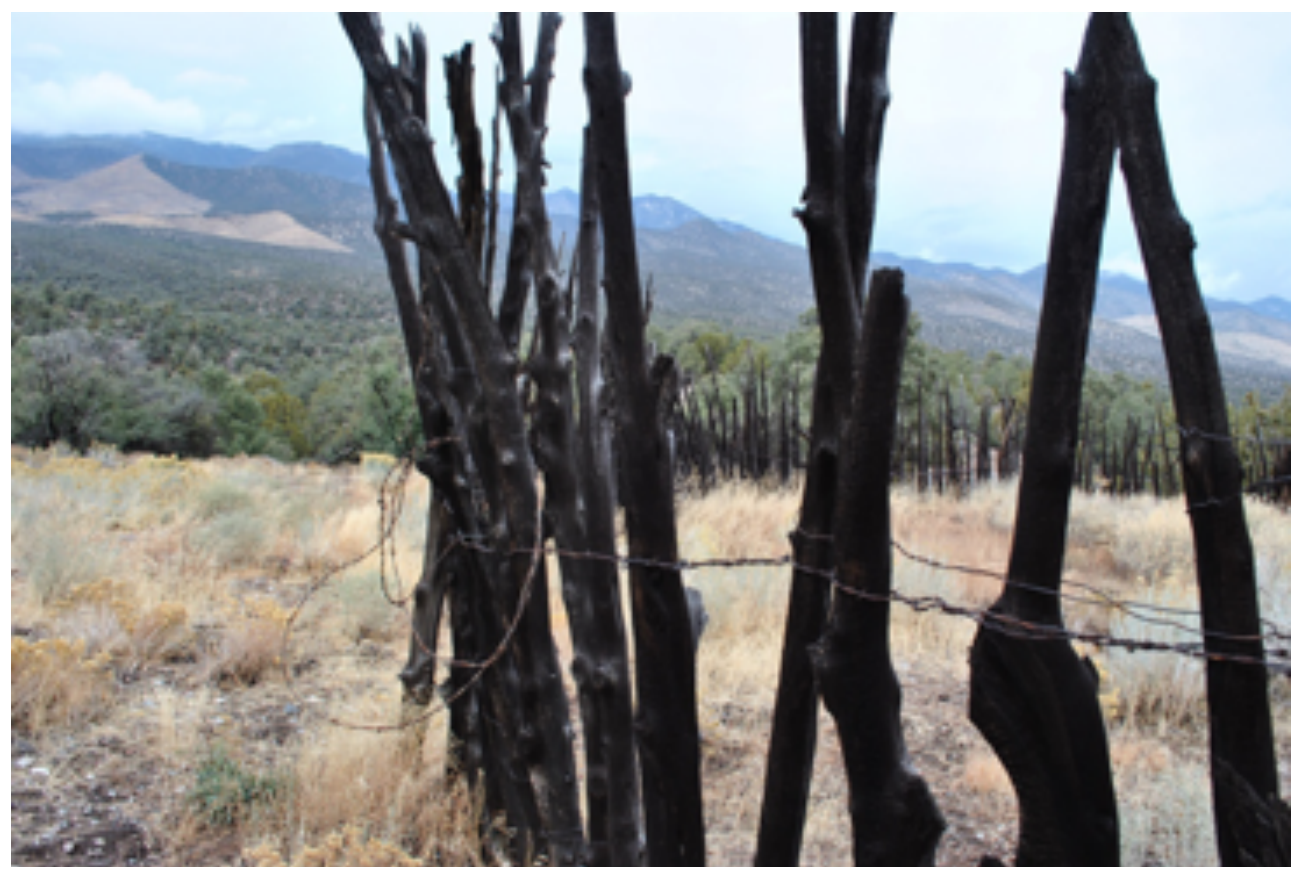

Appendix E. Spring Profile Spring 9, Las Vegas Range, continued

\begin{tabular}{|c|c|}
\hline Prehistory & $\begin{array}{l}\text { - Nuwuvi name documented in the deliverable to } \\
\text { USFWS (Geggus and Spoon, 2018) } \\
\text { - Important pine nut harvesting site and processing } \\
\text { camp, likely a frequented, significant area based } \\
\text { on abundant resources there. } \\
\text { - It is assumed the spring was tended to, but not } \\
\text { sure how Native Americans modified. }\end{array}$ \\
\hline \begin{tabular}{|l} 
Prehistoric \\
Archaeology \\
(located within 0.5 \\
mile radius from \\
spring)
\end{tabular} & $\begin{array}{l}\text { - } \text { Overview: (estimated from Early to Late Archaic } \\
\text { 6oo B.C.- 70o A.D.) } \\
\text { - } \quad \text { Lithic scatters: flaked stone debitage, projectile } \\
\text { points, bifaces, incised stone, ground stone tools } \\
\text { - } \text { Ceramic sherds } \\
\text { - } \text { Roasting pits }(\mathrm{n}=2) \\
\text { - } \text { Dugout shelters }(\mathrm{n}=2) \\
\text { - } \text { Newly recorded in this study: } \\
\text { - } \text { Two lithic scatter sites recorded } \\
\text { On ridge southeast of the spring. } \\
\text { On PJ slope northeast of spring, site includes area } \\
\text { around and downslope from the wildlife camera }\end{array}$ \\
\hline
\end{tabular}




\begin{tabular}{|c|c|}
\hline Historical Use & $\begin{array}{l}\text { Spring may have been used by travelers along } \\
\text { Mormon Road (Mormons from Salt Lake City, and } \\
\text { other travelers, traders) } \\
\text { 1896-1957: Grazing by private holders of spring } \\
\text { water rights (including Spring } 9 \text {, Spring } 10 \text {, } \\
\text { Sawmill Springs) permits issued by Bureau of } \\
\text { Land Management until } \sim 1969 \text {. Overgrazing noted } \\
\text { in } 1946 . \\
\text { 1961- present : Wildlife conservation }\end{array}$ \\
\hline \begin{tabular}{|l} 
Historical \\
Archaeology \\
(located within o.5 \\
mile radius from \\
spring)
\end{tabular} & $\begin{array}{ll}\text { - } & \text { Juniper corral (listed NRHP 1974) } \\
\text { - } & \text { Brush and post enclosure/fencing } \\
\text { - } & \text { Refuse/ debris, can scatters, glass bottles, boot } \\
& \text { heel } \\
\text { - } & \text { Spring developments }\end{array}$ \\
\hline $\begin{array}{l}\text { Water Rights \& } \\
\text { History of } \\
\text { Development }\end{array}$ & $\begin{array}{l}\text { 1896: Private rights holders ("PRH”) 1,2, } \\
\text { and } 3 \text { claim to have been in continuous possession } \\
\text { and use of the water for watering stock } \\
\text { 1909-1950s Private rights holder } 2 \text { sold rights to } \\
\text { two individuals from California and Las } \\
\text { Vegas, Private rights holder 4, and } 5 \text { (also held } \\
\text { rights to Spring } 10 \text { and Sawmill Springs). } \\
\text { 1946: Impacts of overgrazing cattle noted at MW } \\
\text { and parts of the eastern Sheep Range, signaled to } \\
\text { the District Grazier. } \\
\text { 1955: Extensive use of bulldozer and dynamite in } \\
\text { attempt to open up vein of water, the natural } \\
\text { aquifer has been closed off, faulted, or damaged. } \\
\text { Doubtful can be rehabilitated. Flow reduced } \\
\text { to negligable. Barrel sunk at spring head where } \\
\text { modern-day box is, pipeline to large storage tank, } \\
\text { from which led another pipeline to a smaller } \\
\text { concrete stock watering tank several hundred feet } \\
\text { downstream (these plugged up and dry in 1959). } \\
\text { 1957: Spring apparently abandoned/not in use for } \\
\text { the livestock use permit as designated by the water } \\
\text { right and BLM permit. USFWS interest in } \\
\text { developing the spring, outlines several possible } \\
\text { plans of action to make more water available to } \\
\text { wildlife. }\end{array}$ \\
\hline
\end{tabular}




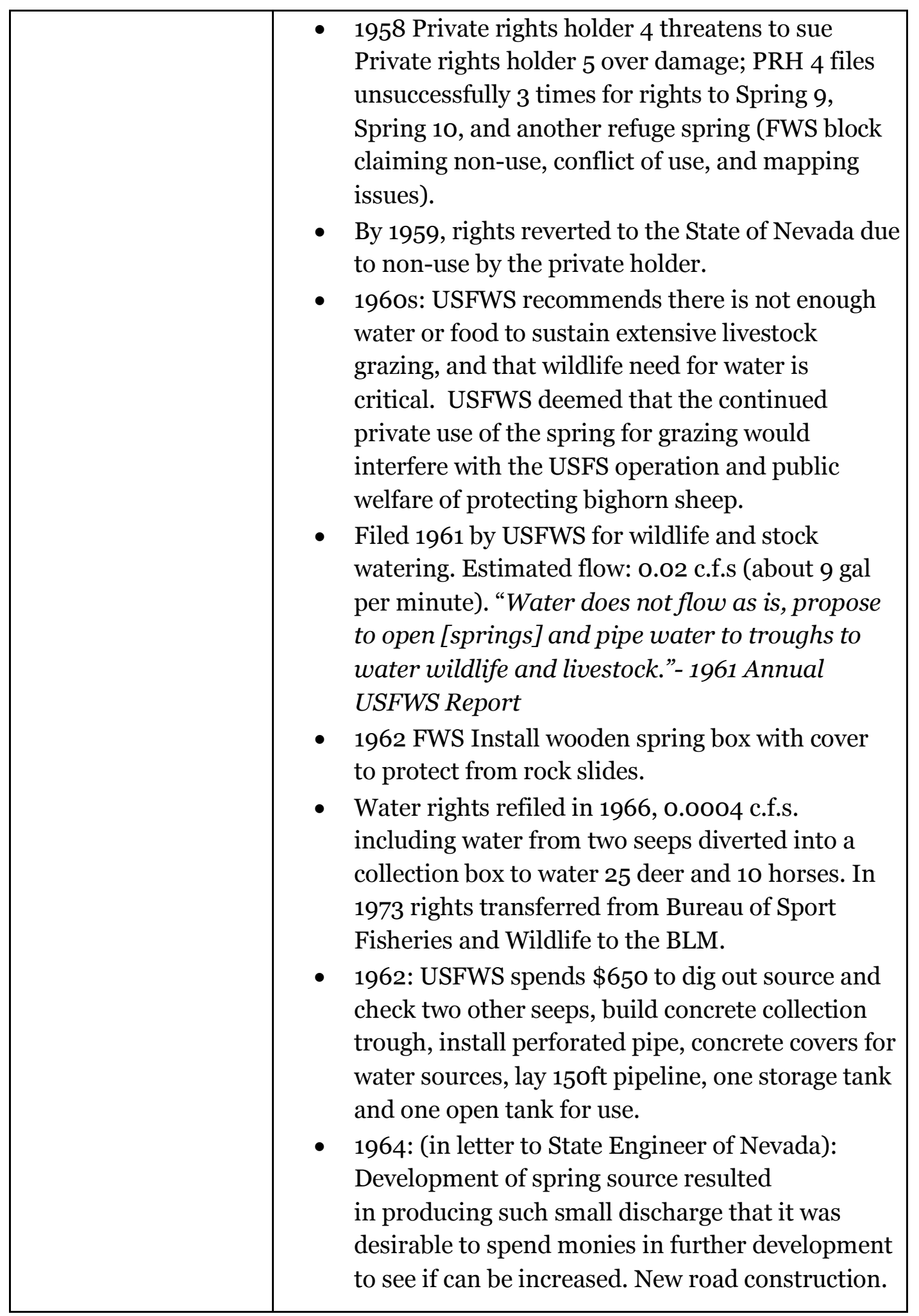




\section{Appendix F. Situating Springs in the Pre-Human, Geological, and Global Context}

Environmental change entails a complex, ongoing interplay between human-driven and non-human processes occurring at multiple scales. Positioning the springs within the long span of geologic time and breadth of global processes is fundamental to historical ecology research and provides context for understanding current and future climate dynamics. Paleoclimatology research reveals that the pre-human "baselines" of spring form and function encompassed a vast range of variation both within and between geologically defined time periods (Enzel et al. 2003).

\section{Spring Paleo-Hydrology}

The springs in Desert NWR occur in the dissolved crevices of carbonate limestone and dolomite, the bedrock formed from the deposited skeletons of Paleozoic marine organisms. Three hundred million years ago, this ancient seabed underwent major u ift and formed the Sheep and Las Vegas Mountains. At some point during this Eon of continental drift, numerous glacial advances and retreats, and drastic extinction events and speciation, the upland springs systems developed. The earliest data on regional paleosprings I could locate are based on studies of paleontology, sediments and chemical isotopes analysis and offer insight stretching only 50,000 years BP.

As groundwater dependent ecosystems, springs are shaped and respond to climatic factors playing out near and far. Local patterns and rates of 
precipitation, temperature, evapotranspiration, and other multi-scalar climatic factors are key abiotic components of spring ecosystems (Laczniak et al. 2000). Springwater once fell as precipitation and spends various amounts of time filtering into and through an aquifer, bringing the element of time into play. The water of the deep carbonate aquifer fell as rain as many as 10,000 years ago. Thus, former climate patterns still reverberate today, as present ones will shape spring systems in the future.

At the broadest scale, climate patterns are generated in large part from the "external forcing" of cyclical shifts in the Earth's orbit and tilt described by Milankovich (Berger 1988) which influence insolation and interact with large scale terrestrial factors such as ocean currents and carbon cycling. For the last 1 million years, 100,000-year colder periods of widespread glaciation have alternated with warmer interglacial periods lasting 10,000 to 30,000 years. Other major non-human forces that determine climate include solar output, and volcanic eruptions. Using climate systems as one example, taking a wide scope elucidates how spring conditions are underpinned by systems at the global, regional, and local scale.

During the last pluvial period, 40,000 to 10,000 years ago, precipitation was typically twice the modern mean annual precipitation. The increased precipitation and cooler temperatures resulted in much higher recharge and elevated water tables of both local, perched aquifers and regional aquifers compared to today; regional water tables were between $10 \mathrm{~m}$ and $120 \mathrm{~m}$ higher. 
Analysis of paleo-discharge and paludal sediments of the Central Region Flow System (Swadley and Carr 1987) confirm that discharge from springs greatly exceeded that which occurred during historical time. Analysis of Late Pleistocene packrat middens reveal that the Sheep Range constituted the northern limit of pinyon pine (Pinus monophylla), now widespread throughout the Great Basin (Thompson et al. 1982). The valleys of Southern Nevada were wetlands and basins harbored pluvial lakes (Faunt et. al n.d.). At the end of the Pleistocene, the climate underwent a warming and drying trend which caused declines in the water table, changes in distribution of vegetation zones, and reduction of spring flows, wetlands and riparian areas (Swadley and Carr 1987). 


\section{Appendix G. Priority appropriation of water rights for the ten springs included in this survey presented in chronological order (USFWS archives, accessed 2016)}

\begin{tabular}{|c|c|c|c|c|c|c|}
\hline Spring & Range & $\begin{array}{l}\text { Date of Priority } \\
\text { Appropriation }\end{array}$ & $\begin{array}{l}\text { Type } \\
\text { of Water } \\
\text { Right }\end{array}$ & $\begin{array}{l}\text { Water } \\
\text { Rights } \\
\text { Holder }\end{array}$ & $\begin{array}{l}\text { Amount } \\
\text { Appropriated } \\
\text { (c.f.s) }\end{array}$ & Beneficial Use \\
\hline \multirow{3}{*}{$\begin{array}{l}\text { Spring } \\
9\end{array}$} & \multirow{3}{*}{\begin{tabular}{|l} 
Las \\
Vegas
\end{tabular}} & 1896 & $\begin{array}{l}\text { State } \\
\text { appropriative }\end{array}$ & \begin{tabular}{|l|} 
Private \\
rights \\
holders
\end{tabular} & .02 & Stockwatering \\
\hline & & 1909-1959 & State appropriative & \begin{tabular}{|l|} 
Private \\
rights \\
holders
\end{tabular} & .02 & Stockwatering \\
\hline & & 1961 & Adjudicated & USFWS & .02 & Wildlife watering \\
\hline \multirow{3}{*}{$\begin{array}{l}\text { Spring } \\
10\end{array}$} & \multirow{3}{*}{$\begin{array}{l}\text { Las } \\
\text { Vegas }\end{array}$} & 1896 & State appropriative & \begin{tabular}{|l|} 
Private \\
rights \\
holders
\end{tabular} & 0.01 & Stockwatering \\
\hline & & 1909-1959 & State appropriative & \begin{tabular}{|l|} 
Private \\
rights \\
holders
\end{tabular} & .01 & Stockwatering \\
\hline & & 1961 & Adjudicated & USFWS & 0.01 & Wildlife watering \\
\hline \multirow[t]{2}{*}{$\begin{array}{l}\text { Spring } \\
6\end{array}$} & \multirow[t]{2}{*}{ Sheep } & 1928 & State appropriative & \begin{tabular}{|l|}
$\begin{array}{l}\text { Private } \\
\text { rights } \\
\text { holder }\end{array}$ \\
\end{tabular} & 0.001 & $\begin{array}{l}\text { Stockwatering and } \\
\text { domestic }\end{array}$ \\
\hline & & 1939 & Adjudicated & USFWS & 0.001 & Wildlife watering \\
\hline \multirow[t]{2}{*}{$\begin{array}{l}\text { Spring } \\
5\end{array}$} & \multirow[t]{2}{*}{ Sheep } & 1913 & State appropriative & \begin{tabular}{|l|} 
Private \\
rights \\
holder
\end{tabular} & 0.003 & $\begin{array}{l}\text { Stockwatering and } \\
\text { domestic }\end{array}$ \\
\hline & & 1940 & Adjudicated & USFWS & 0.001 & Wildlife watering \\
\hline \multirow[t]{2}{*}{$\begin{array}{l}\text { Spring } \\
7\end{array}$} & \multirow[t]{2}{*}{$\begin{array}{l}\text { Las } \\
\text { Vegas }\end{array}$} & prior to 1936 & State appropriative & \begin{tabular}{|l|} 
Private \\
rights \\
holder
\end{tabular} & no data & Stockwatering \\
\hline & & 1950 & Adjudicated & USFWS & 0.00049 & Wildlife watering \\
\hline \multirow[t]{2}{*}{$\begin{array}{l}\text { Spring } \\
3\end{array}$} & \multirow[t]{2}{*}{ Sheep } & $1930 \mathrm{~s}$ & State appropriative & \begin{tabular}{|l|}
$\begin{array}{l}\text { Private } \\
\text { rights } \\
\text { holder }\end{array}$ \\
\end{tabular} & no data & Stockwatering \\
\hline & & 1947 & Adjudicated & USFWS & 0.001 & Wildlife watering \\
\hline \multirow[t]{2}{*}{$\begin{array}{l}\text { Spring } \\
2\end{array}$} & \multirow[t]{2}{*}{ Sheep } & $1930 \mathrm{~s}$ & State appropriative & $\begin{array}{l}\text { Private } \\
\text { rights } \\
\text { holder }\end{array}$ & no data & Stockwatering \\
\hline & & 1951 & Adjudicated & USFWS & .000625 & Wildlife watering \\
\hline $\begin{array}{l}\text { Spring } \\
1\end{array}$ & Sheep & 1941 & $\begin{array}{l}\text { Federally reserved } \\
\text { in } 1937\end{array}$ & USFWS & 0.001 & Wildlife watering \\
\hline $\begin{array}{l}\text { Spring } \\
4\end{array}$ & Sheep & 1946 & $\begin{array}{l}\text { Federally reserved } \\
\text { in } 1937\end{array}$ & USFWS & 0.001 & Wildlife watering \\
\hline $\begin{array}{l}\text { Spring } \\
8 \\
\end{array}$ & \begin{tabular}{|l|} 
Las \\
Vegas \\
\end{tabular} & 1951 & $\begin{array}{l}\text { Federally reserved } \\
\text { in } 1937\end{array}$ & USFWS & 0.001 & Wildlife watering \\
\hline
\end{tabular}

